\title{
National Register Evaluation of Eight Sites at Camp Swift Army National Guard Training Center, Bastrop County, Texas: Swift V
}

Jon C. Lohse

C. Britt Bousman

Department of Anthropology, Texas State University

Follow this and additional works at: https://scholarworks.sfasu.edu/ita

Part of the American Material Culture Commons, Archaeological Anthropology Commons, Environmental Studies Commons, Other American Studies Commons, Other Arts and Humanities Commons, Other History of Art, Architecture, and Archaeology Commons, and the United States History Commons

Tell us how this article helped you.

This Article is brought to you for free and open access by the Center for Regional Heritage Research at SFA ScholarWorks. It has been accepted for inclusion in Index of Texas Archaeology: Open Access Gray Literature from the Lone Star State by an authorized editor of SFA ScholarWorks. For more information, please contact cdsscholarworks@sfasu.edu. 


\section{National Register Evaluation of Eight Sites at Camp Swift Army National Guard Training Center, Bastrop County, Texas: Swift V}

\section{Creative Commons License}

\section{(c) (1) \&}

This work is licensed under a Creative Commons Attribution-NonCommercial 4.0 International License 


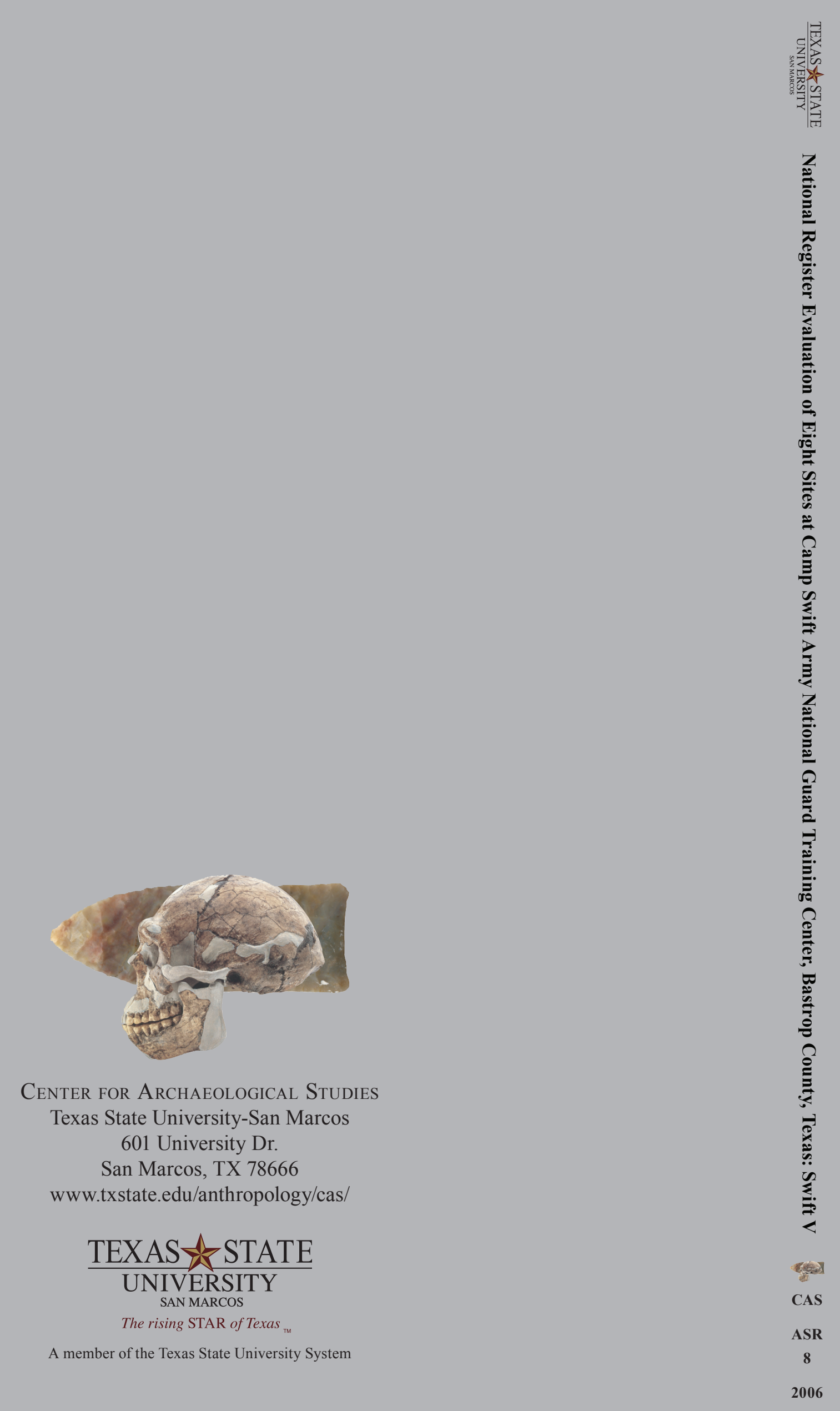

National Register Evaluation of Eight Sites at

Camp Swift Army National Guard Training Center, Bastrop County, Texas: Swift V

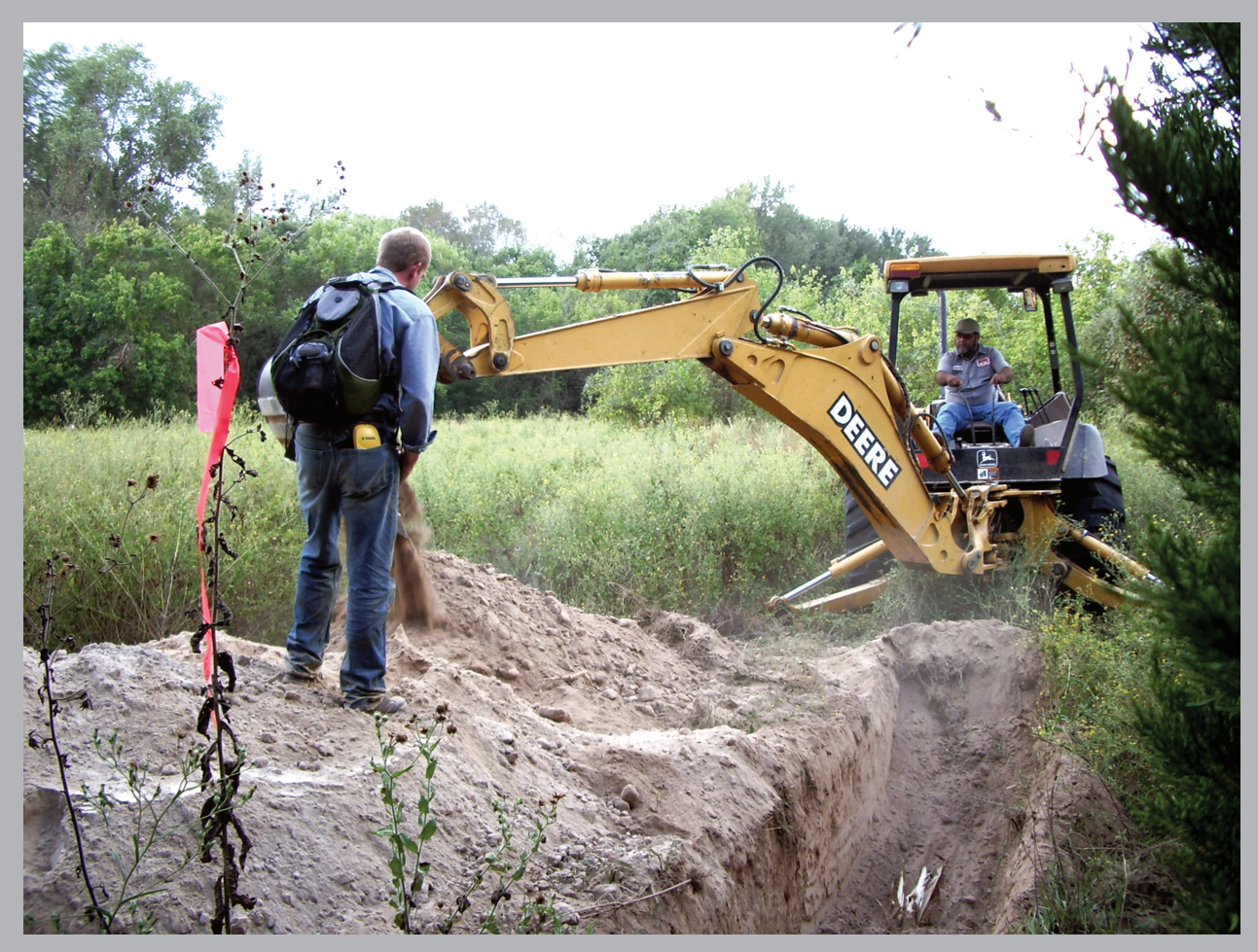

By Jon C. Lohse and C. Britt Bousman

Principal Investigators: C. Britt Bousman and Jon C. Lohse

Archaeological Studies Report No. 8 


\section{National Register Evaluation of Eight Sites at \\ Camp Swift Army National Guard Training Center, \\ Bastrop County, Texas: Swift V}

Jon C. Lohse and C. Britt Bousman

Principal Investigators:

C. Britt Bousman and Jon C. Lohse 
The following information is provided in accordance with the General Rules of Practice and Procedures, Title 13, Chapter 26, Texas Administrative Code:

1. Type of investigation: National Register evaluation of site potential with backhoe trenching.

2. Project name: National Register Evaluation of Eight Sites at Camp Swift Army National Guard Training Center, Bastrop County, Texas: Swift V.

3. County: Bastrop

4. Principal Investigators: C. Britt Bousman and Jon C. Lohse

5. Name and location of sponsoring agency: The Adjutant General's Department of Texas, Directorate of Facilities and Engineering, Environmental Branch, Austin, Texas.

6. Published by the Center for Archaeological Studies, Texas State University-San Marcos, 601 University Drive, San Marcos, Texas, 78666-4616 (2006)

Texas State University-San Marcos is a member of the Texas State University System Copyright (C) 2006 by the Center for Archaeological Studies at Texas State University-San Marcos

All rights reserved.

No part of this book may be reproduced or utilized in any form or by any means, electronic or mechanical, including photocopying, recording,

or by any information storage and retrieval system

without permission in writing.

For further information on this and other publications by

the Center for Archaeological Studies, please contact:

Center for Archaeological Studies

Texas State University-San Marcos

601 University Drive

San Marcos, TX 78666-4616

www.txstate.edu/anthropology/cas/

Editor: Maggie Moore

Cover Photograph: CAS archaeologist David Payton monitoring excavation of backhoe trenching at 41BP105, 2005.

Printed in the United States of America

by

Ginny’s Printing Inc., Austin 


\section{Management Summary}

\section{Management Objectives}

The Texas Army National Guard (TXARNG) conducts military training on Camp Swift, an approximately 11,500-acre tract in northern Bastrop County, Texas. The TXARNG is responsible for complying with federal legislation regarding the assessment and management of environmental and cultural resources. An earlier cultural resources assessment by the Center for Archaeological Studies (CAS), Texas State University-San Marcos, conducted under compliance with Section 106 of the National Historic Preservation Act (NRHP), identified 11 sites deemed potentially capable of contributing meaningful information on the record of prehistoric human occupation at Camp Swift. In particular, Criterion D of National Park Service Rule 36 CFR Part 60, addressing sites or properties that have yielded, or may be likely to yield, information important in prehistory or history, is often used for assessing the potential NRHP eligibility of Camp Swift prehistoric sites. These 11 sites were shown by survey and shovel tests to contain or potentially contain significant cultural deposits including intact burned rock features. Eight of these sites (41BP105, 41BP111, 41BP113, 41BP118, 41BP121, 41BP471, 41BP491, 41BP528), containing robust deposits but no specific features, were selected for more extensive examination before recommendations for additional research could be finalized. This work was carried out by CAS archaeologists in October of 2005. The remaining three (41BP91, 41BP100, 41BP471) will be examined in more detail through a combination of hand-excavated units and backhoe trenching in a future effort. The current report describes the results of work carried out at the eight sites, evaluates those findings in a local and regional culture historical framework, and provides recommendations to the TXARNG for treatment of those sites so that they can fulfill their Section 106 obligations.

\section{Conclusions and Recommendations}

Sites in this region are commonly viewed by regulators and policy makers as problematic because of the loosely consolidated nature of the sandy sediments that comprise them. Serious consideration has been given to whether cultural deposits can be considered intact, or enough so that any future work is capable of providing meaningful and reliable information. Current findings are considered with respect to this issue. Regardless of the resolution of the so-called "sandy mantle" debate, the entire chronology of occupations across Camp Swift remains poorly understood and maintains significant gaps for which no known archaeological components have been identified, particularly for time periods preceding the Late Archaic. It is felt that, though such components are demonstrably present, they are likely to be deeply buried and infrequent. Filling in the occupation sequence, or, alternatively, explaining from empirical data why gaps exist, should remain one of the central elements of any additional work conducted at the installation for the foreseeable future. This standing recommendation should assist the TXARNG in complying with State and Federal statutes that outline their (TXARNG) obligation for appropriately managing potentially significant cultural resources. 
Features or possible features were recorded at four sites (41BP111, 41BP121-Area B, 41BP471, and 41BP528), and multiple features were observed at 41BP113. A sixth site, 41BP491, produced artifacts in deep sands that may be the result of natural deposition. Additional testing with 1x1$\mathrm{m}$ units is recommended at these six sites. No features and limited artifacts were encountered at two of the eight sites considered in this report (41BP105 and 41BP118), and no further work is recommended for these. Furthermore, special attention should be paid to dating deposits by singlegrain optically stimulated luminescence dating at the six sites recommended for further testing, as well as all other sites in future investigations. Also, detailed analysis of the vertical distributions of prehistoric and historic artifacts should be documented in all future investigations. This work is necessary to assess whether these loosely consolidated landforms are intact and capable of containing stratigraphically-ordered deposits. 


\section{Table of Contents}

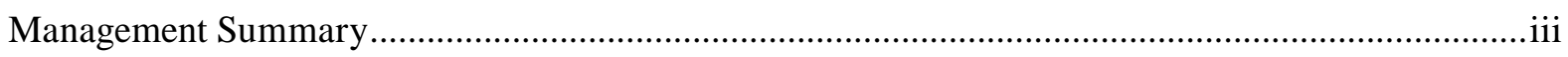

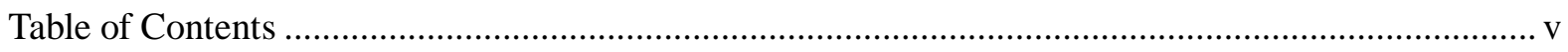

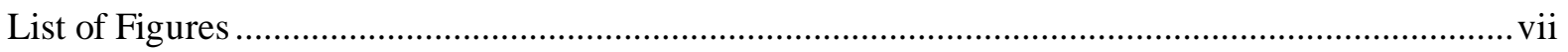

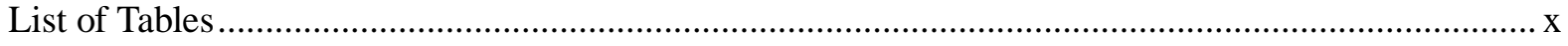

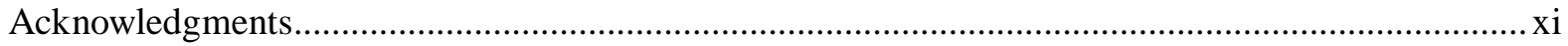

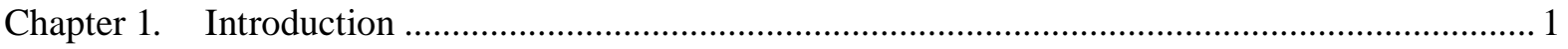

Chapter 2. Project Area Description and Culture History …......................................................... 5

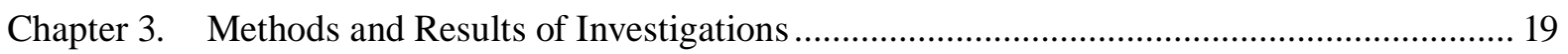

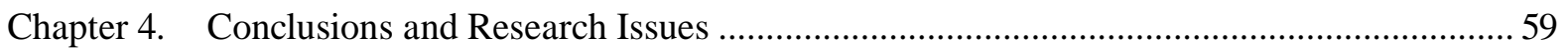

Chapter 5. Recommendations for Site Management and Future Work........................................... 73

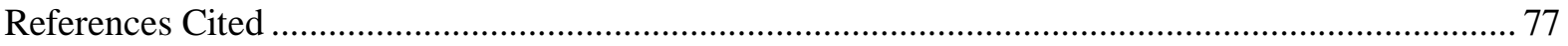




\section{LiST OF Figures}

1-1. Location of Camp Swift in Bastrop County, Texas

2-1. Map of Camp Swift showing important drainages and approximate locations of

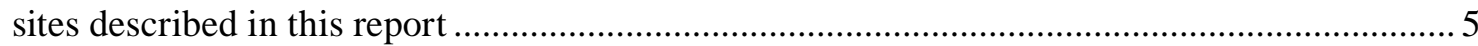

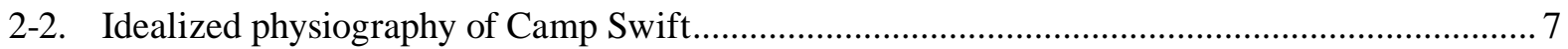

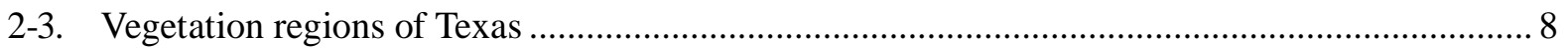

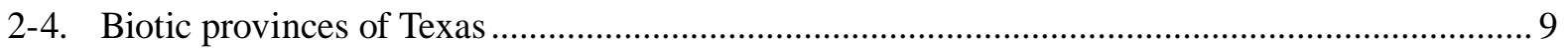

2-5. Chronology chart for the Camp Swift study area, reflecting artifact styles

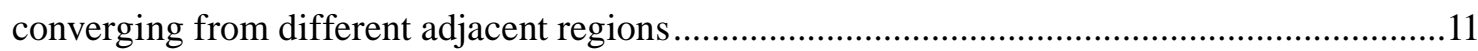

3-1. Map of 41BP105 showing locations of backhoe trenches and 2002-2003 shovel tests.............. 20

3-2. CAS archaeologist David Payton monitoring backhoe trenching at 41BP105 ........................ 21

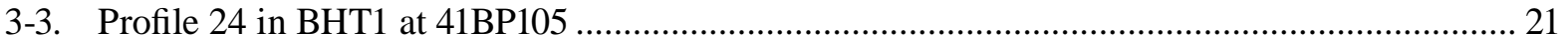

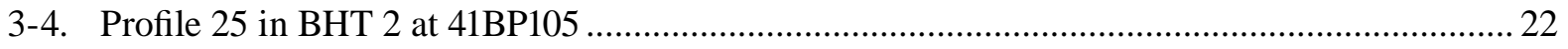

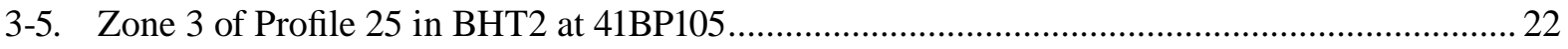

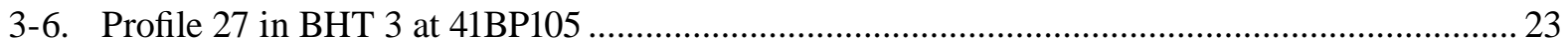

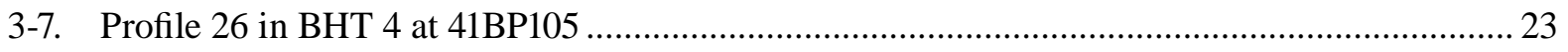

3-8. Artifacts recovered from 41BP105 at depths of between 100 and 120 cmbs............................ 24

3-9. Map of 41BP111 showing locations of backhoe trenches and 2002-2003 shovel tests .............. 25

3-10. Disturbed hearth of fire-cracked rock eroding out of the ridge ............................................... 26

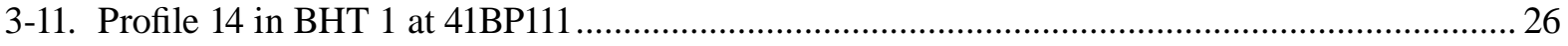

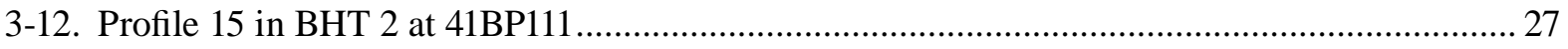

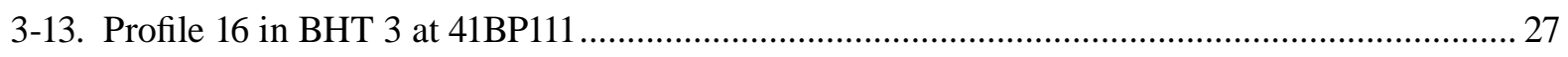

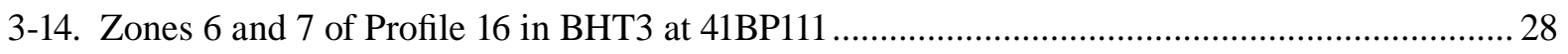

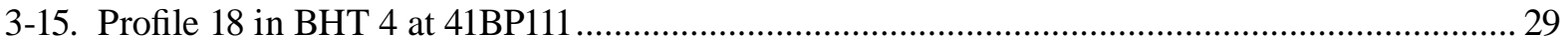

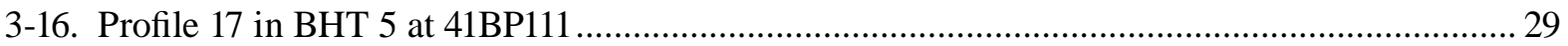

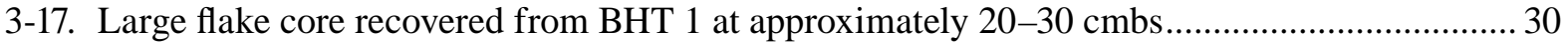

3-18. Map of 41BP113 showing locations of backhoe trenches and 2002-2003 ............................... 31 


\section{List OF Figures (Continued)}

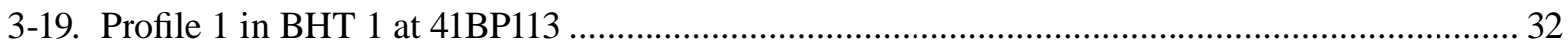

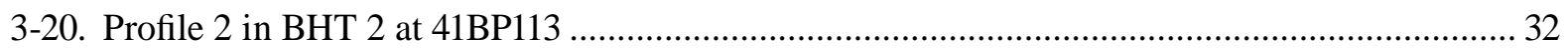

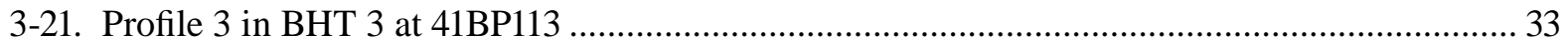

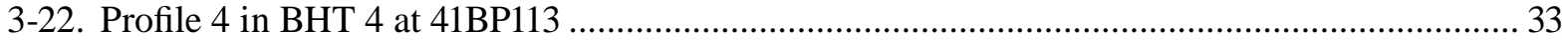

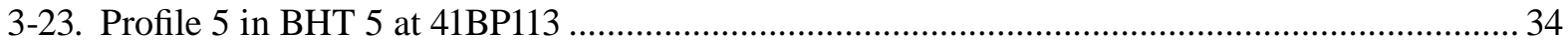

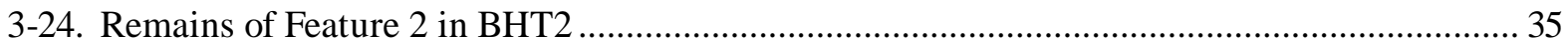

3-25. Fire-cracked and other rocks removed from a single backhoe bucket that disturbed

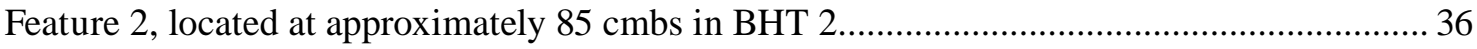

3-26. Feature 3 in BHT 3 at approximately 85 cmbs, looking southwest...................................... 36

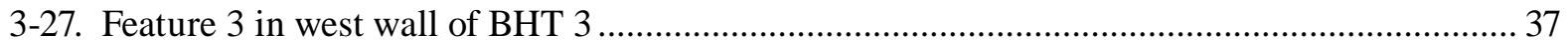

3-28. Large interior bifacial thinning flake of "root beer brown" chert from BHT 3........................ 37

3-29. Late Archaic dart point base made of Edwards chert, found in BHT 3 .................................. 37

3-30. Map of 41BP118 showing locations of backhoe trenches and 2002-2003 shovel tests .............. 38

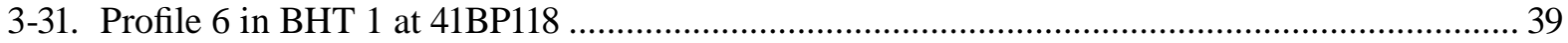

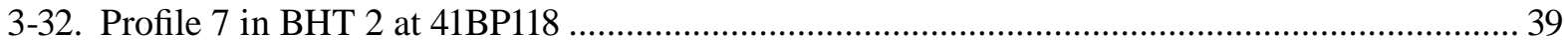

3-33. CAS archaeologist David Payton indicating the heavy natural gravels in BHT 1 at 41BP118 40

3-34. Map of 41BP121 showing locations of backhoe trenches and 2002-2003 shovel tests.............. 41

3-35. Examples of the varying depths of sandy sediments found at 41BP121 ................................. 42

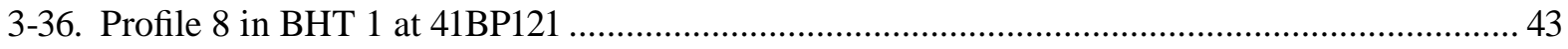

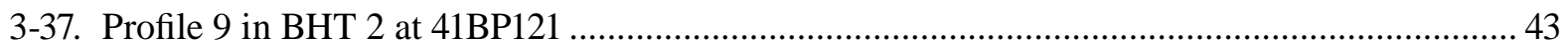

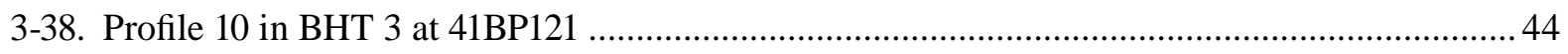

3-39. Map of 41BP471 showing locations of backhoe trenches and 2002-2003 shovel tests............. 45

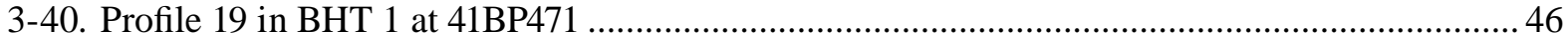

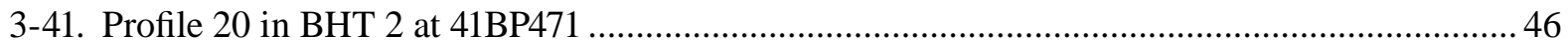

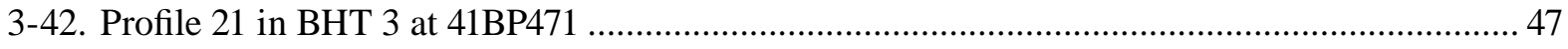




\section{List OF Figures (CONTINUed)}

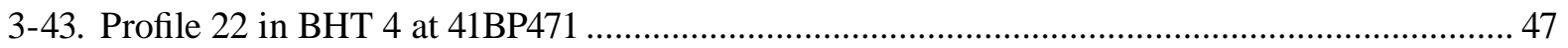

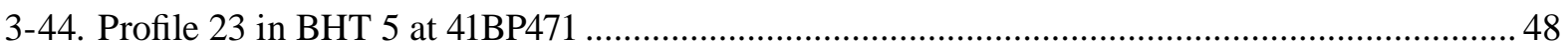

3-45. Small cluster of large fire-cracked rocks from BHT 1 at 41BP471 ........................................ 49

3-46. Feature 1, recorded in BHT 5, looking south and east............................................................ 49

3-47. Fire-cracked rocks from Feature 1, BHT 5 at 41BP471 …...................................................... 50

3-48. Large chert flake recorded at 50 cmbs in BHT 4 at 41BP471 ................................................ 50

3-49. Map of 41BP491 showing locations of backhoe trenches and 2002-2003 shovel tests.............. 51

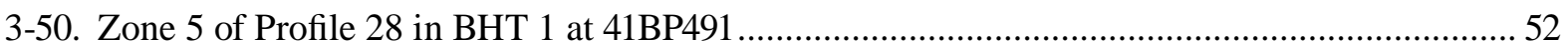

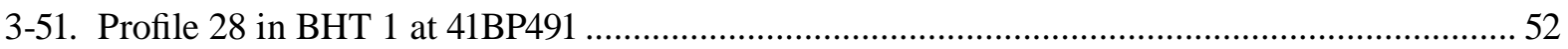

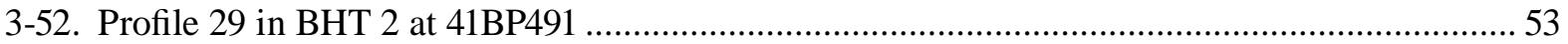

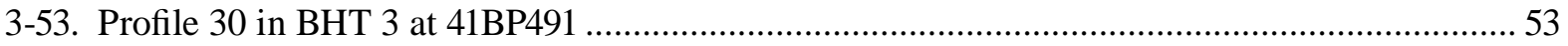

3-54. Depth of sandy sediments in BHT 1 at 41BP491, looking south ............................................. 54

3-55. Map of 41BP528 showing locations of backhoe trenches and 2002-2003 shovel tests.............. 55

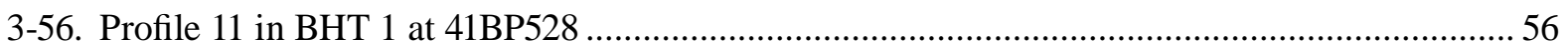

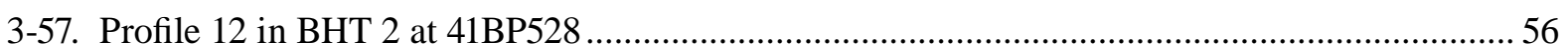

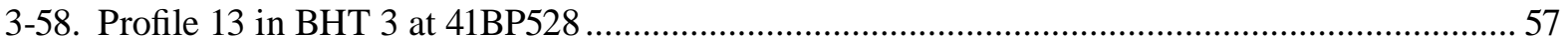

3-59. South wall profile of BHT3, showing total sediment depths of just over one meter .................. 58

4-1. Temporal components per 100 years based on diagnostic artifacts recovered so far

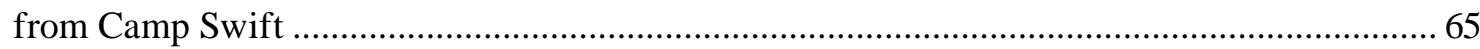

4-2. Compiled ${ }^{14} \mathrm{C}$ results from Nickels (in prep) from excavated features at Camp Swift, arranged in ascending order by age

4-3. Compiled ${ }^{14} \mathrm{C}$ results from Nickels (in prep), arranged by depth of sample below surface to show apparently unpatterned distribution of samples by age. 


\section{List OF TABLES}

1-1. Sites investigated in the current phase of research ............................................................. 4

2-1. Common soils at Camp Swift with their settings and textures ........................................... 8

2-2. Vegetation communities, species inventories, and settings commonly found across

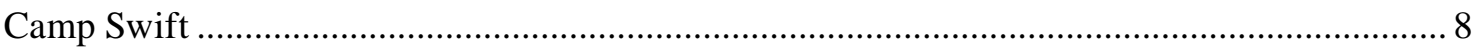

2-3. Mammals and reptiles commonly found in the Texan biotic province .................................... 9

3-1. Approximate depths of artifact recovery from backhoe trenches at 41BP105 ........................ 24

3-2. Approximate depths of artifact recovery from backhoe trenches at 41BP111 ........................... 30

3-3. Approximate depths of artifact recovery from backhoe trenches at 41BP113.......................... 35

3-4. Approximate depths of artifact recovery from backhoe trenches at 41BP118.......................... 40

3-5. Approximate depths of artifact recovery from backhoe trenches at 41BP121 ......................... 44

3-6. Approximate depths of artifact recovery from backhoe trenches at 41BP471 ….................... 48

3-7. Approximate depths of artifact recovery from backhoe trenches at 41BP491 …...................... 54

3-8. Approximate depths of artifact recovery from backhoe trenches at 41BP528 ….................... 57

4-1. List of features recorded in the current effort by site, depth, and site landform ....................... 65

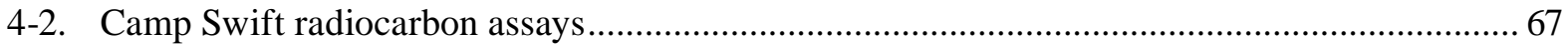

5-1. Recommendations for sites assessed at Camp Swift .............................................................. 75 


\section{AcKNOWLedgments}

The author wishes to thank Ms. Kristen Wentzel, Cultural Resource Manager for the Texas Army National Guard, for her support and enthusiasm for this project. The Camp Swift facility manager, Master Sergeant Anderson, coordinated access to the camp during field work, and his cooperation is appreciated. David L. Nickels was extremely supportive and encouraging through all phases of this project. His advice and consultation concerning sandy mantle archaeology has enriched this report. Fieldwork was performed by Jon Lohse and David Payton. David's able assistance was greatly appreciated. Geological profiles were described by Britt Bousman with the assistance of Jon Lohse. At the Center for Archaeological Studies, Carole Leezer provided important logistical and administrative support for this effort. Matt Melancon and Damon Stone provided assistance with many of the images, and Maggie Moore produced and edited the report. 



\section{Chapter 1}

\section{Introduction And Project Background}

The Texas Army National Guard(TXARNG) bears the responsibility for inventorying, assessing, and managing the cultural resources at Camp Swift, located in Bastrop County, Texas. In 2002-2003, the Center for Archaeological Studies (CAS) at Texas State University-San Marcos conducted a number of shovel tests at 39 prehistoric, historic, and multi-component sites located on Camp Swift (Figure 1-1; Nickels and Lehman 2004a). On the basis of the 2002-2003 work and after considering the potential of those sites to have additional cultural deposits capable of informing about important issues in local, regional, and state history or prehistory, recommendations were made for further work at 11 sites. After communications with the Texas Historical Commission - Department of Antiquities Protection (THC) and TXARNG, CAS personnel were contracted to carry out limited exploration by backhoe at eight sites to search for intact cultural features, specifically hearths and burned rock clusters. This approach was undertaken instead of a traditional testing strategy as an experimental trial to determine if a less expensive strategy could be implemented that would provide a viable assessment of site significance. This report describes those efforts, considers the findings in the context of prehistoric occupation at Camp Swift, and makes additional recommendations regarding future treatment of the eight sites.

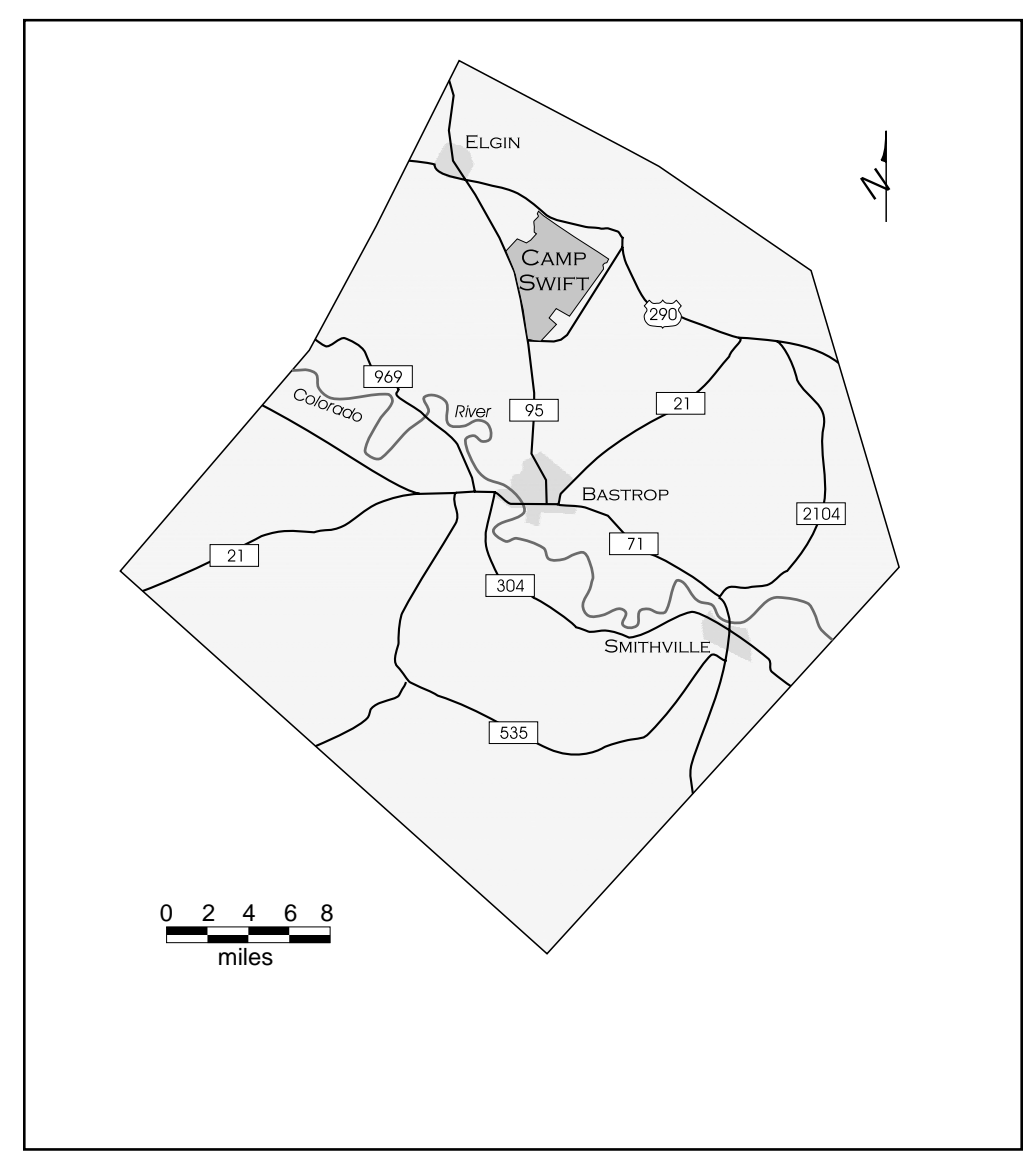

Figure 1-1. Location of Camp Swift in Bastrop County, Texas. 


\section{Project Background: Regulatory Overview}

The Environmental Resources Management Office of the TXARNG is charged with oversight, management, and compliance with Federal legislation regarding assessment and treatment of archaeological resources on TXARNG properties. Cultural resource compliance required of TXARNG is addressed in Sections 106 and 110 of the National Historic Preservation Act (NHPA) of 1966. The NHPA also created the Advisory Council for Historic Preservation (ACHP) and the National Register of Historic Places (NRHP), a registry managed by the National Park Service of both historic and prehistoric sites that have been deemed important in local, regional, or state contexts across the United States. According to the NHPA, the ACHP, through local State Historic Preservation Officers (SHPOs, part of THC in the state of Texas), must be given the opportunity to comment when any cultural resources potentially eligible for inclusion in the NRHP are present in any area affected by a Federal agency or by actions funded or permitted by Federal agencies. Amendments to the NHPA in 1992 clarified Section 110 and directed Federal agencies to establish preservation programs corresponding to their activities and anticipated effects on historic and prehistoric properties. Under the amended Section 110, Federal agencies may evaluate the significance of cultural resources not currently threatened in order to assist with development and preservation planning. The ACHP drafted regulations that guide the process of assessing site significance and potential eligibility for listing to the NRHP; that process is described in ACHP Regulation 36 CFR 800. Criteria for determining NRHP eligibility hinge on the concept of "significance" defined in National Park Service Rule 36 CFR Part 60. These criteria address sites or properties that are: a) associated with events that have made a significant contribution to the broad patterns of our history; or

b) that are associated with lives or persons significant in our past; or

c) that embody the distinctive characteristics of a type, period, or method or construction, or that represent the work of a master, or that possess high artistic values, or that represent a significant and distinguishable entity whose components may lack individual distinction; or

d) that have yielded, or may be likely to yield, information important in prehistory or history.

Of these, criterion (c) is most commonly used to assess the significance of sites with standing architecture. Criterion (d) is most often applied to prehistoric sites; successful application of this criterion depends on a number of factors involving both internal site integrity and the nature of the regional archaeological record as currently understood. As such, the kinds of information that are deemed "important in prehistory or history" are, or should be, considered fluid and subject to change through time as more information becomes available and, importantly, as new questions, perspectives, and/or analytical techniques are introduced that are capable of yielding a new understanding of extant data.

\section{Research Background and Objectives}

In response to the 1992 Section 110 amendments, TXARNG developed an Integrated Cultural Resource Management Plan for its installations. Previous surveys at Camp Swift have been conducted under this management plan (Meissner, ed. 1991; Nickels et al. 2003; Nickels 
and Lehman 2004a; Nickels et al. 2005) as well as for other regulatory compliance (Nash et al. 1995; Nightengale and Moncure 1996; Schmidt and Cruse 1995; Skelton and Freeman 1979; Sullo and Wormser 1996). These surveys have identified a total of 181 sites (Nickels 2005a:1), some of which were previously recorded and some representing new discoveries.

Recommendations from these surveys have resulted in two separate testing projects: one currently being reported by CAS, and the effort described in this report. The survey that resulted in the work reported here (Nickels and Lehman 2004a) originally recommended that 11 sites be tested, as shovel probes had either yielded considerable cultural deposits or had exposed intact burned rock features such as hearths. Upon reviewing the initial testing proposal prepared by CAS, THC expressed concerns regarding the potential for sites at Camp Swift to contain intact or stratified evidence of cultural occupation, as the area is partly characterized by loosely consolidated sandy sediments (see Bruseth and Martin 2001). Following negotiations between THC, CAS, and TXARNG, eight of the 11 sites were selected for this preliminary phase of testing (Table 1-1), with field efforts restricted to backhoe trenching to prospect for intact features (Bousman and Nickels 2004). The approach of backhoe trenching used in this current project was different from normal hand-excavated test units. This project undertook this experimental strategy, which focused on discovering intact features at the expense of artifact recovery through the excavation of $1 \times 1-m$ units by hand. As with previous investigations at Camp Swift, key issues to be investigated included (1) formation of the sandy mantle, (2) depths of the sandsheet, and (3) chronological occupation of Camp Swift. To address these questions, backhoe trenches were excavated at each site.
The remaining three sites, together with sites from the current eight that demonstrate a likelihood for containing intact features, will be tested by hand-excavated units in a future phase of research. The scope of work for this follow-up phase of testing will be developed based in part on the results of the current project (Bousman and Nickels 2004:13).

In the current effort, the presence, type, and approximate depth of cultural material were recorded for each trench. Trenches were excavated to the underlying sterile clay substratum whenever possible. Exceptions occurred when intact features were encountered or the trench depths were deemed to be unsafe. These data, along with the shovel tests conducted during the survey phase, will be useful in helping to characterize what kinds of activities might be represented at each site. All sediment profiles were described to help refine models of landform formation and geomorphology at Camp Swift (described in Chapter 2), and to correlate these with site distributions and types. Encountered features were recorded by provenience and described. Additionally, time-diagnostic artifacts were collected. Together with the growing record of diagnostic artifacts reported by previous projects and chronometric dates, these will help refine the understanding of when prehistoric peoples occupied the Camp Swift area.

The following chapter of this report describe the environmental setting of Camp Swift including soils, geology, hydrology, flora, and fauna. A review of the prehistoric and early historic culture history is also presented. Each site is described in Chapter 3 along with the results of the backhoe trenching that was performed. Chapter 4 reviews research frameworks proposed for Camp Swift and how sites in the current study hold the potential to 
Table 1-1. Sites investigated in the current phase of research.

\begin{tabular}{|c|c|c|c|c|c|c|c|}
\hline Site No. & Type & $\begin{array}{c}\text { Area } \\
\left(\mathbf{m}^{2}\right)\end{array}$ & $\begin{array}{l}\text { Elevation } \\
\text { (ft amsl) }\end{array}$ & $\begin{array}{c}\text { Geomorphic } \\
\text { Setting, } \\
\text { Nearby } \\
\text { Waterways } \\
\end{array}$ & Soil & $\begin{array}{c}\text { Deepest } \\
\text { Artifact } \\
\text { Recovery }\end{array}$ & $\begin{array}{l}\text { Recommended } \\
\text { Level of Effort }\end{array}$ \\
\hline 41BP105 & $\begin{array}{c}\text { open } \\
\text { campsite }\end{array}$ & 3,845 & $410-420$ & $\begin{array}{c}\text { lower terrace, } \\
\text { Big Sandy Creek }\end{array}$ & Sa & $110 \mathrm{~cm}$ & 4 BHTs \\
\hline 41BP111 & $\begin{array}{c}\text { open } \\
\text { campsite, } \\
\text { lithic } \\
\text { reduction }\end{array}$ & 23,049 & $450-475$ & $\begin{array}{l}\text { ridge and } \\
\text { sideslope, } \\
\text { McLaughlin } \\
\text { Creek }\end{array}$ & $\mathrm{PaE}$ & $100 \mathrm{~cm}$ & 5 BHTs \\
\hline $41 \mathrm{BP} 113$ & $\begin{array}{c}\text { open } \\
\text { campsite }\end{array}$ & 20,500 & $450-460$ & $\begin{array}{l}\text { sideslope, } \\
\text { McLaughlin } \\
\text { Creek }\end{array}$ & $\mathrm{PaE}$ & $110 \mathrm{~cm}$ & 5 BHTs \\
\hline 41BP118 & $\begin{array}{c}\text { open } \\
\text { campsite }\end{array}$ & 1,095 & $450-460$ & $\begin{array}{l}\text { sideslope, } \\
\text { McLaughlin } \\
\text { Creek }\end{array}$ & CsC2 & $120 \mathrm{~cm}$ & 2 BHTS \\
\hline 41BP121 & $\begin{array}{c}\text { open } \\
\text { campsite }\end{array}$ & 37,582 & $455-465$ & sideslope & $\mathrm{DeC}$ & $110 \mathrm{~cm}$ & 3 BHTs \\
\hline 41BP471 & $\begin{array}{c}\text { open } \\
\text { campsite }\end{array}$ & 25,693 & $440-450$ & $\begin{array}{l}\text { open sideslope, } \\
\text { spring-fed } \\
\text { drainage }\end{array}$ & $\mathrm{PaE}$ & $130 \mathrm{~cm}$ & 5 BHTs \\
\hline 41BP491 & $\begin{array}{c}\text { open } \\
\text { campsite }\end{array}$ & 4,382 & $465-475$ & $\begin{array}{l}\text { upland setting, } \\
\text { tributary of Big } \\
\text { Sandy Creek }\end{array}$ & $\mathrm{SkC}$ & $100 \mathrm{~cm}$ & 3 BHTs \\
\hline 41BР528 & $\begin{array}{c}\text { open } \\
\text { campsite }\end{array}$ & 2,400 & $465-470$ & $\begin{array}{l}\text { sideslope, } \\
\text { intermittent } \\
\text { drainage of } \\
\text { McLaughlin } \\
\text { Creek }\end{array}$ & $\mathrm{SkC}$ & $60 \mathrm{~cm}$ & 3 BHTs \\
\hline \multicolumn{8}{|c|}{$\begin{array}{l}\text { Soils key: } \\
\text { CsC2: Crockett soils; DeC: Demona loamy fine sand; PaE: Patilo complex soils; } \\
\text { Sa: Sayers fine sandy loam; SkC: Silstid loamy fine sand }\end{array}$} \\
\hline
\end{tabular}

contribute to archaeological research in the area. for future work that will allow the TXARNG In the final chapter, considerations of the results to advance its Integrated Cultural Resource are presented together with recommendations Management Plan. 


\section{Chapter 2}

\section{Project Area Description and Culture History}

This chapter presents an overview of the environmental setting, including soils and sediments, geology, hydrology, flora and fauna of Camp Swift (Figure 2-1). It also describes the culture history for the region, based largely on the syntheses of three nearby archaeological areas (Central, East, and Upper Gulf Coastal Texas) that converge or overlap in Bastrop County. south, respectively. This pattern of land use and settlement leaves large, open, and undeveloped tracts across the county.

Bastrop County in general is drained by the Colorado River, which runs northwest to southeast through the center of the county. Camp Swift in particular is drained by Big

\section{The Natural Environment}

Camp Swift includes
approximately 11,500 acres located in north-central Bastrop County, southeast-central Texas (see Figure 1-1). Bastrop County encompasses approximately 895 square miles on the upper Gulf Coastal plains just south of the Balcones Escarpment (Marks 2001). Agriculture, including cattle grazing, is the primary contemporary land use in the county, along with other activities such as small-scale natural gas and oil exploration, and mineral extraction through mining. Settlementsaregenerally dispersed and of limited size; population centers near the camp include the towns of Elgin and Bastrop, located approximately eight miles to the north and

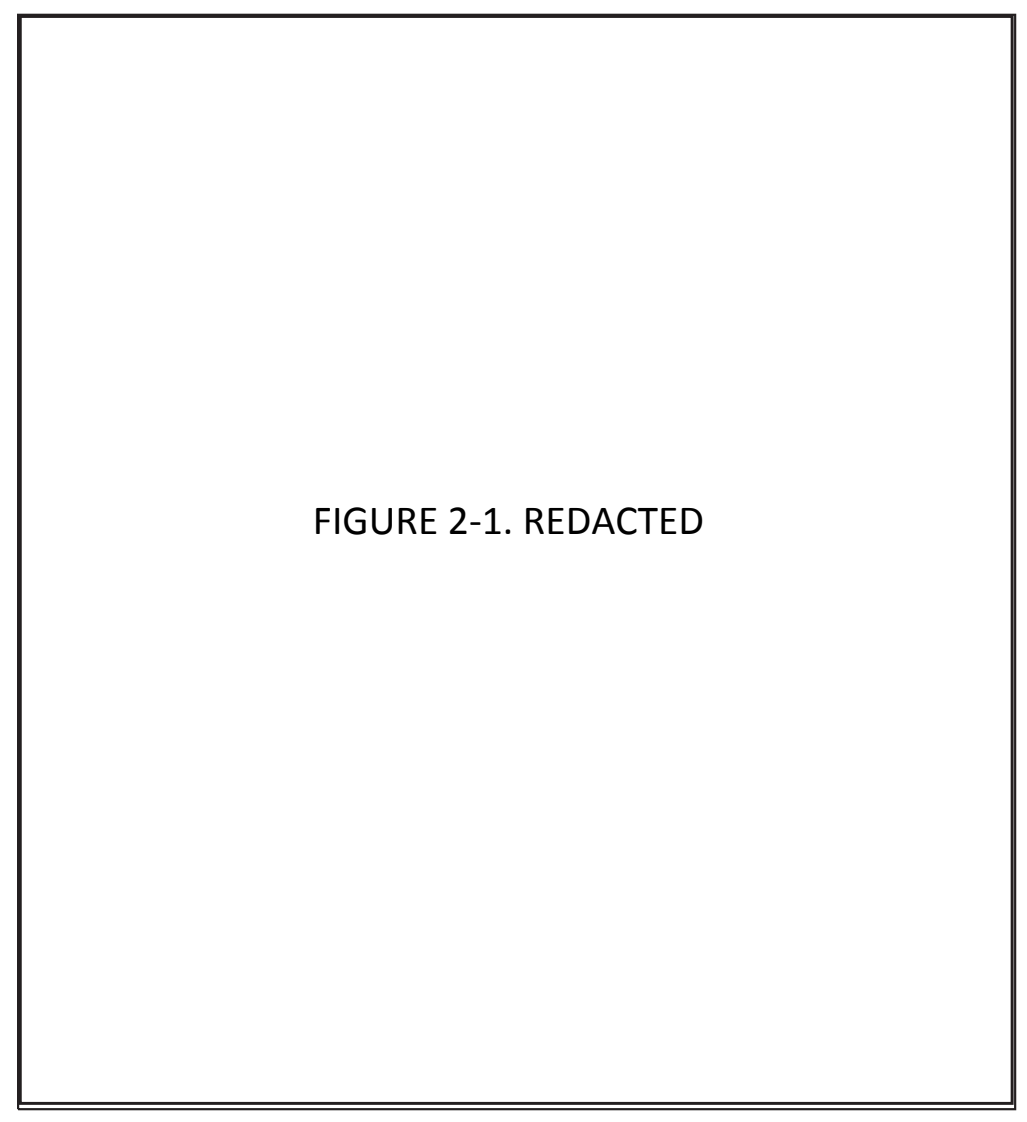

Figure 2-1. Map of Camp Swift showing important drainages and approximate locations of sites described in this report (adapted from Nickels and Padilla 2005:Figure 2-3). 
Sandy Creek and its tributaries, McLaughlin Creek, Dogwood Creek, Dogwood Branch, and Harris Creek, though the latter two are located far to the south of the sites included in the current testing effort (see Figure 2-1). All of these streams are intermittent, with active periods coinciding with heavy rainfall events. Spring Branch creek flows constantly, but seeps into sandy topsoil just before its confluence with Big Sandy. Under average conditions, these streams form standing pools in some places and disappear into the sandy substrata in others. These waterways result in rolling terrain that, though occasionally dramatic, more frequently consists of gently graded uplands. County-wide elevations range from 400 to over 600 feet above mean sea level (ft amsl); elevations of sites described herein range between 410-470 ft amsl.

The climate of this region of Texas is subtropical humid with mild, cool winters and hot, prolonged summers. Fall and spring seasons are brief and often characterized by winter- or summer-like weather patterns. Annual mean temperatures range from $40^{\circ} \mathrm{F}$ in January to a maximum of $96^{\circ} \mathrm{F}$ in July. Extreme highs, though, are several degrees over $100^{\circ} \mathrm{F}$, with infrequent winter storms bringing temperatures well below freezing. Mean annual precipitation is approximately 36.8 inches (Marks 2001); latesummer storms can often bring several inches of rainfall in a single event.

\section{Geology and Soils}

The bedrock formation underlying much of Bastrop County is called the Wilcox Group and it formed during the Paleocene-Eocene Epochs. The Wilcox Group is divided into three formations: the Calvert Bluff Formation, the Simsboro Formation, and the Hooper Formation (Barnes 1974). The Calvert Bluff Formation covers almost all of Camp Swift and is composed of sandstone formations capping mudstone beds with lignite seams and ironstone inclusions (see also Sellards et al. 1932; Wilmarth 1938). Streambeds incising through capping sandstones tend to be both narrower and of steeper gradient then those that course through uncapped areas (Prochnow 2001:31). One result of the relationship between water flow, underlying geology, and pedogenic (soil accumulation and formation) processes is that both stream channels and intervening uplands tend to vary tremendously in their geometry (breadth, slope, aspect) from one part of Camp Swift to another. Similarly, sediment accumulation can be highly variable on a localized (i.e., site-specific) scale.

Overlying the Wilcox Group in some places is a series of lag deposits referred to as Uvalde Gravels (Byrd 1971). This deposit of pebble and cobble-size alluvium dates to the Miocene and Pliocene geologic periods, and consists of quartzite, limestone, chert, silicified wood, and jasper. Most Uvalde Gravel outcrops are found in the northern parts of Camp Swift and commonly occur below the 450-foot elevation contour (Robinson and Meade 2001:4). These poorly sorted deposits are characterized by generally small $(<10 \mathrm{~cm})$ grain size, posing certain restrictions on prehistoric lithic reduction strategies. While some chert gravels are available on Camp Swift, more abundant lithic resources would have been available either in heavier gravel deposits along the Colorado River and its system of primary tributaries, or along the Balcones Escarpment, where outcrops of high quality Edwards Chert occur in seams and veins or are weathered into tabular cobbles.

Most of the camp is covered with sandy soils that originated primarily from weathering of parent bedrock, and were deposited locally through alluvial, colluvial, and possibly eolian processes. Sometimes referred to as the Big 
Brushy formation, this Holocene "sandy mantle" varies in thickness and reflects a dynamic and complex history of formation (Bousman and Fields 1988; Frederick and Bateman 2001). Soil orders found across the camp include entisols or mollisols on floodplains and terraces, and alfisols in the uplands and slopes (Barker 1979). Mollisols in the region derive from resistant mineral parent materials and are found on active, even unstable geomorphic surfaces that undergo processes such as flooding, erosion, truncation, or dramatic impact from human activity (Wilding 2000:E-180). While mollisols in the camp generally have coarse-grained but internally consistent textures, alfisols, in contrast, are characterized by translocation of clay particles that form argillic horizons or lamellae. Thin A-horizons are often present over entisols and mollisols (Waters 1992:54).

A number of localized environmental settings, or physiographic zones, have been identified at Camp Swift by previous CAS projects (Nickels 2003a, 2004a; Nickels and Padilla 2005) and other researchers (Prochnow 2001) on the basis of terrain, slope, and proximity to water. These include active floodplains or drainageways, terraces, uplands, ridges, and foot and side slopes (Figure 2-2). Floodplains and elevated terraces are found along drainages, which are quite active. Uplands, ridgetops, and associated slopes separate both perennial and intermittent stream channels. The soil series most commonly identified at Camp Swift on these settings are listed in Table 2-1.

\section{Flora and Fauna}

Camp Swift is characterized by a rich diversity of plant and animal communities that inhabit its different environmental settings. The distribution of individual species follows along factors such as soil type, soil depth, and availability of water, and is also conditioned by larger, well-defined state-wide biotic and vegetation provinces (Blair 1950; Gould 1975).

Camp Swift is situated within the Post Oak Savannah vegetation region described for Texas (Gould 1975). The Post Oak Savannah is also referred to as Oak Woods and Prairies or Oak-Hickory Forest. Adjacent to the Blackland Prairie, which also makes up a significant portion of Bastrop County, Post Oak Savannah stretches from southeast of San Antonio all the way to the Red River in far northeast Texas (Figure 2-3). This range includes plant communities identified as post red-oak cedar, mesquite brushlands, old field, and riparian (Skelton and Freeman 1979). Each community can be associated with a distinct inventory of species, with some general overlap, and found in prescribed slope and soil conditions (Table 2-2).

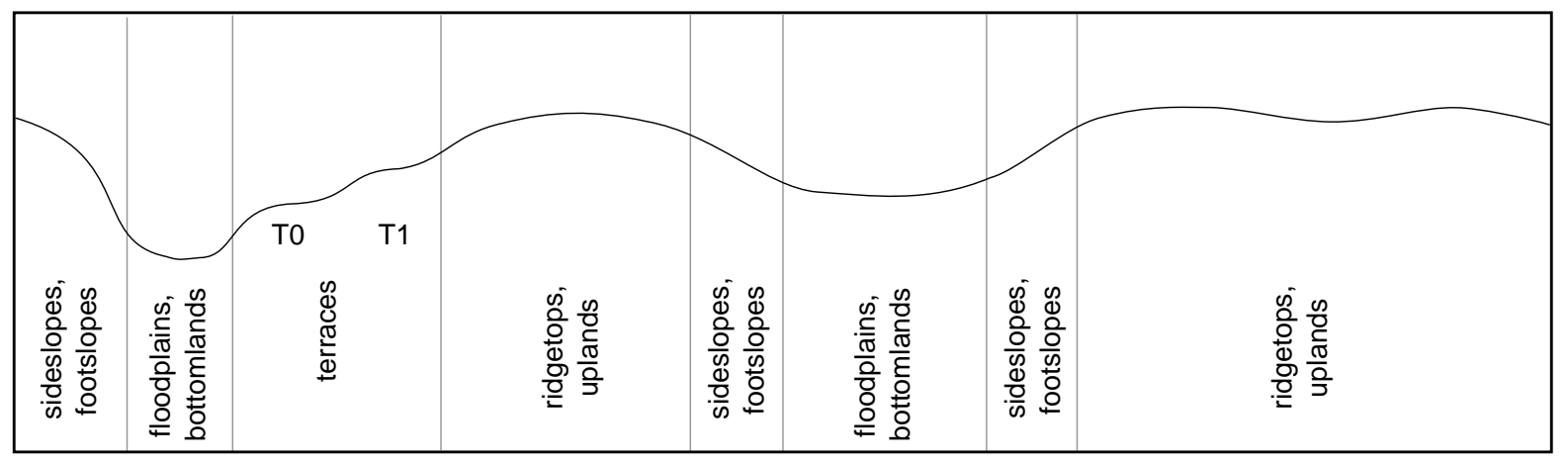

Figure 2-2. Idealized physiography of Camp Swift. 
Table 2-1. Common soils at Camp Swift with their settings and textures (adapted from Nickels 2003a:Table 2-1).

\begin{tabular}{|c|c|c|}
\hline Soils & Settings & Textures \\
\hline Axtell series & terraces and uplands & fine sandy loam \\
\hline Demona series & $\begin{array}{c}\text { ridgetops, sideslopes, upland } \\
\text { drainageways }\end{array}$ & loamy fine sand \\
\hline Patilo series & uplands & fine sand \\
\hline Silstid series & uplands & loamy fine sand \\
\hline Tabor series & broad uplands & fine sandy loam \\
\hline Gowen series & floodplains, bottomlands & clay loam \\
\hline
\end{tabular}

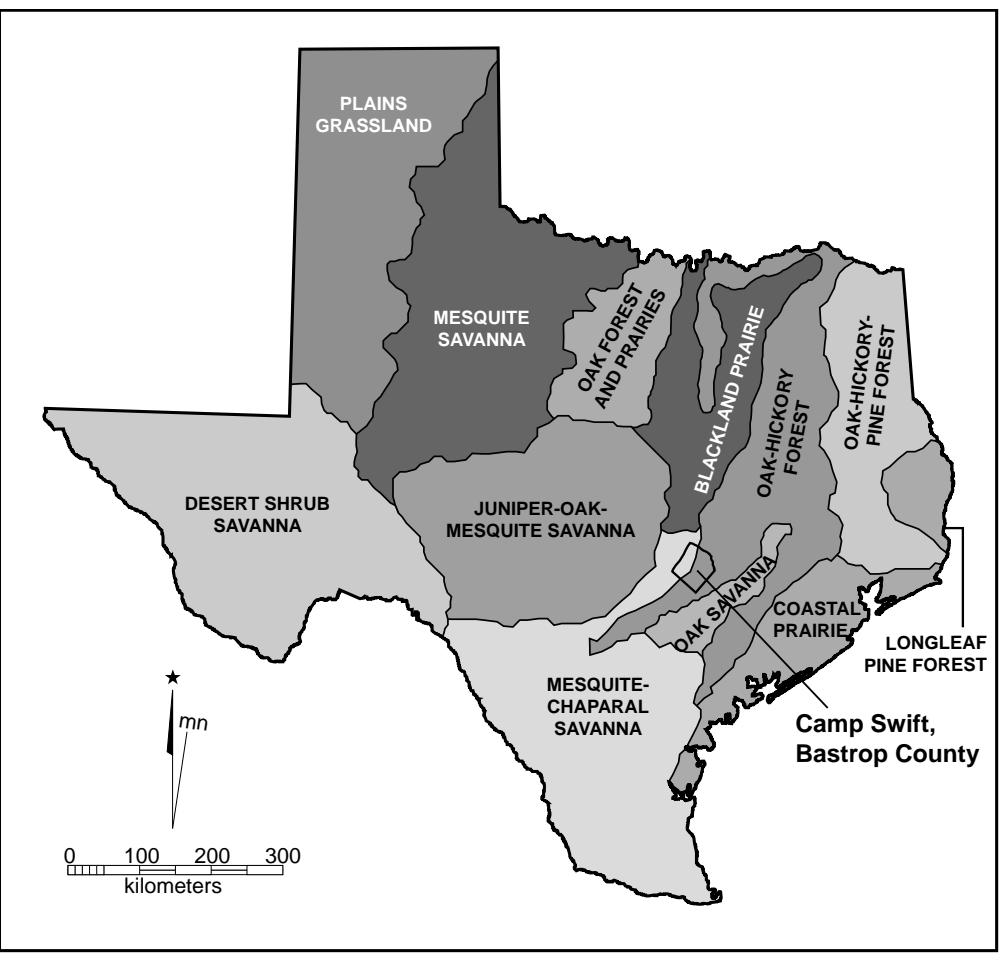

Figure 2-3. Vegetation regions of Texas (adapted from Gould 1975).

Table 2-2. Vegetation communities, species inventories, and settings commonly found across Camp Swift (adapted from Nickels 2003a:Table 2-2; Robinson and Meade 2001).

\begin{tabular}{|c|c|c|c|}
\hline Plant Community & Species Inventories & Settings & Soils \\
\hline $\begin{array}{c}\text { Post Oak- } \\
\text { Red Cedar }\end{array}$ & post oaks, red cedar & uplands, ridgetops, upper slopes & deep sands \\
\hline $\begin{array}{c}\text { Mesquite } \\
\text { Brushlands }\end{array}$ & $\begin{array}{c}\text { mesquite, red cedar, } \\
\text { hackberry, winged elm }\end{array}$ & $\begin{array}{c}\text { disturbed agricultural fields (e.g., } \\
\text { knoll tops, slopes) }\end{array}$ & $\begin{array}{c}\text { loams and sands, } \\
\text { often eroded }\end{array}$ \\
\hline Old Field & mixed grasses & $\begin{array}{c}\text { disturbed agricultural fields (e.g., } \\
\text { floodplains, valley margins) }\end{array}$ & $\begin{array}{c}\text { thick alluvial and } \\
\text { colluvial sands }\end{array}$ \\
\hline Riparian & $\begin{array}{c}\text { red cedar, black willow, elm, } \\
\text { cottonwood, black hickory, } \\
\text { pecan, post oak, hackberry }\end{array}$ & $\begin{array}{c}\text { floodplains, alluvial deposits } \\
\text { (e.g., terraces) }\end{array}$ & $\begin{array}{c}\text { thick alluvial and } \\
\text { colluvial sands }\end{array}$ \\
\hline
\end{tabular}


The Texan biotic province (Blair 1950), defined by consistent mammal and reptile population and diversity clines, extends from the Red River in north Texas to the Gulf of Mexico in southeast Texas (Figure 2-4). This province separates the Austroriparion province to the east from the Kansan, Balconian, and Tamaulipan provinces to the west. Animal species present here favor the open and mixed forest environments and prairie land settings that characterize this large region. Mammals are in general medium to small in size and, with the exception of bison and Pleistocene megafauna, this is presumed to be true for the prehistoric period as well. Common species found in this province are listed in Table 2-3 (also Nightengale

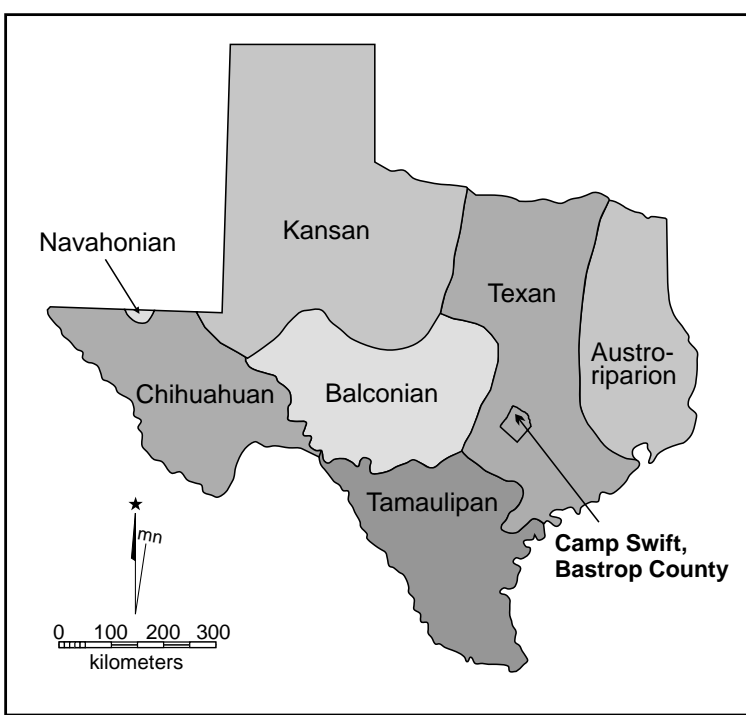

Figure 2-4. Biotic provinces of Texas (adapted from Blair 1950). and Moncure 1996; Skelton and Freeman 1979).

Table 2-3. Mammals and reptiles commonly found in the Texan biotic province (adapted from Nickels 2003a:Table 2-3).

\begin{tabular}{|c|c|}
\hline Common Name & Scientific Name \\
\hline white tailed deer & Odocoileus virginianus \\
\hline wild hog & Sus scrofa \\
\hline coyote & Canis latrans \\
\hline cougar & Felis concolor \\
\hline bobcat & Lynx rufus \\
\hline grey fox & Urocyon cinereoargenteus \\
\hline racoon & Procyon lotor \\
\hline striped skunk & Mephitis mephitis \\
\hline eastern cottontail & Lepus californicus, Sylvilagus floridanus \\
\hline nine-banded armadillo & Dasypus novemcinctus \\
\hline opossum & Didelphis virginana \\
\hline rabbits/hares: black tailed jackrabbit, & Geomus bursarius \\
\hline squirrels: grey, spotted ground & Sciurus carolinensis, Spermophilus spilosoma \\
\hline plains pocket gopher & Peromyscus leucopus, Peromyscus truei, \\
Reithrodontomys fulvescens
\end{tabular}




\section{Culture History}

Bastrop County lies at the convergence of three traditionally recognized and welldescribed archaeological regions of Texas (Goode 1989). These include Central Texas, East Texas, and the Upper Gulf Coastal area. Early summaries of the cultural record of Central Texas were presented by Suhm (1957), Johnson et al. (1962), Sorrow et al. (1967), Weir (1976), and Prewitt (1981, 1985). More recently, Collins $(1995,2004)$ has reviewed and synthesized archaeological data and aspects of the paleoenvironmental records from Central Texas. Fields (1995) has synthesized the Post Oak Savannah region, which extends into East Texas, though focuses primarily on the record available from study areas located slightly north of Bastrop County. Patterson (1995), following Story et al. (1990), has examined the record found in southeast Texas. Each region - Central, East, and Upper Gulf Coastal - has been distinguished on the basis of diagnostic artifact styles, and together they reflect an increase in the development of well-established regional traditions through time. Below, major periods are discussed as they are represented in the material record of the project area (Figure 2-5). Many of the time-diagnostic points found across Camp Swift are placed in different periods by other researchers; such prevarication is the result of some of these artifact styles having spans as long as a thousand or more years, and also of the regional chronologies that converge in the Camp Swift area.

\section{Paleoindian}

Originally defined as a nomadic way of life reliant on big-game hunting (Wormington 1957), the Paleoindian period corresponds in time with the end of the Pleistocene and very beginning of the Holocene era at approximately 10,000 years ago.
Paleoindians were the first Americans, and it is not currently known exactly when they first arrived into the New World. Clovis, the earliest defined material assemblage, is consistent (or nearly so) across the entire North American continent and can be dated to around 11,500 to 10,900 years ago; antecedants to these early settlers are simply referred to as pre-Clovis. Archaeologists understand that Paleoindians in general were highly nomadic; relied heavily though not exclusively on hunting large game animals, many of which became extinct by the end of the Pleistocene; and often exhibited settlement preferences for protected habitats with nearby water and high quality stone for tool-making. For projects where adequate research has been carried out, evidence shows the high degree to which Paleoindians also relied upon small game, including aquatic resources, and indicates the exploitation of plants to the point that it is no longer appropriate to refer to Paleoindians as exclusively big game hunters. Recent summaries of Paleoindian sites and archaeology are available in Bousman et al. (2004), Collins (1998, 2004), and Hester (2004).

The Paleoindian period was one of a dramatically different environment than found today, with much lower average temperatures and generally wetter conditions. By the beginning of the Holocene, sufficient regional variation is evident in toolkits and artifact assemblages to warrant separation of the Paleoindian period into early and late phases. Distinctive Early Paleoindian artifacts include Clovis points and associated assemblages, as well as Folsom and Midland. Late Paleoindian finds indicate a regionalized proliferation of types, suggesting that the degree of residential mobility was diminishing, even if slightly, as populations restricted themselves to smaller seasonal rounds. 


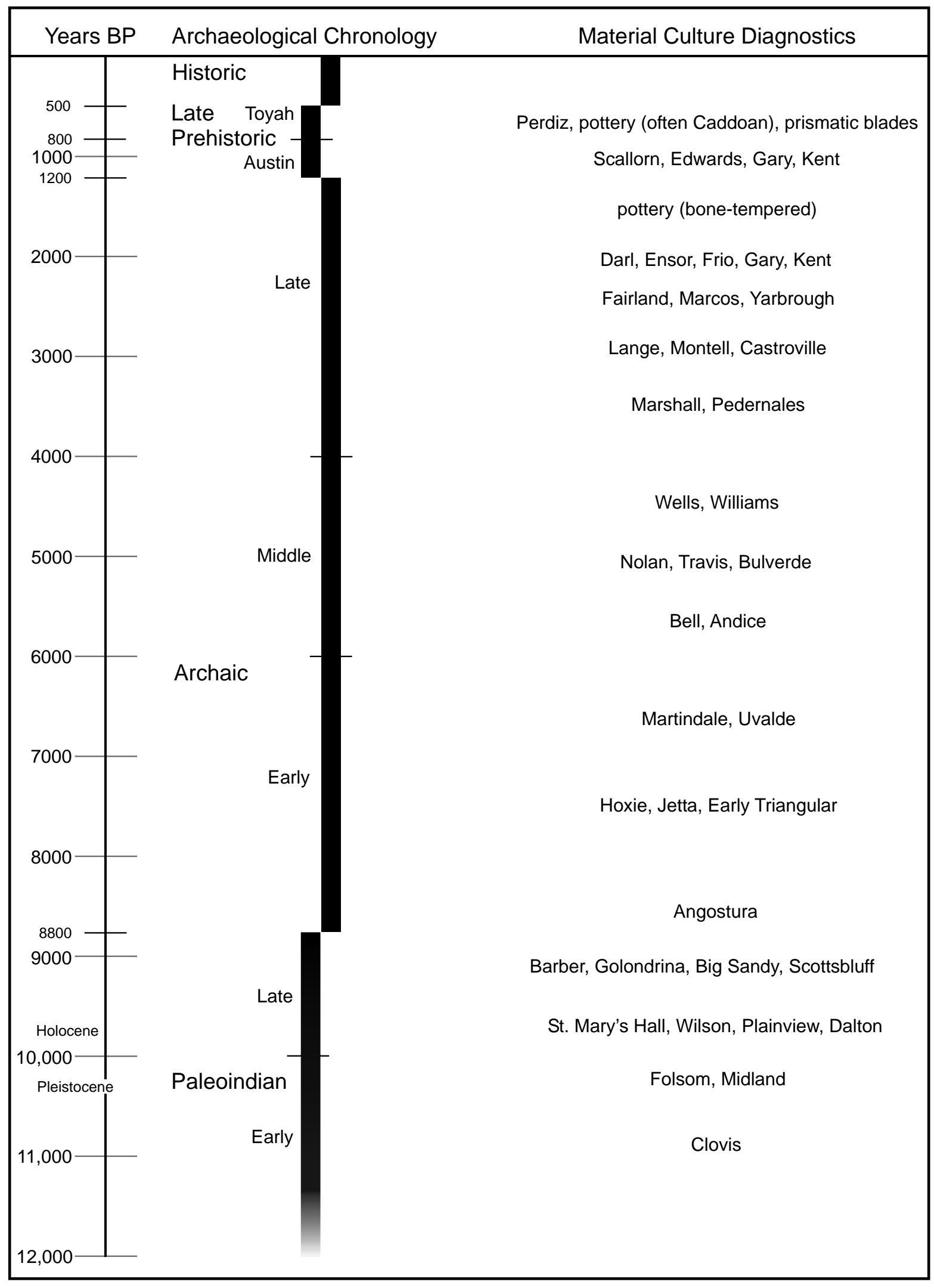

Figure 2-5. Chronology chart for the Camp Swift study area, reflecting artifact styles converging from different adjacent regions. 
Clovis points are lanceolate in shape (as are most Paleoindian point types) and are thinned at the base by removal of one or more channel flakes, or flutes. These are often associated with the remains of mammoth, mastodon, horse, bison, and sometimes camel. Artifacts commonly found with Clovis points include prismatic blades and blade cores; tools on blades such as gravers, scrapers, and serrated cutting tools; and distinctive bifaces. Clovis flaking technology involved the controlled removal of overshot flakes that extended from one side of a biface to the other; when found in discrete assemblages, these flakes are as distinctive of Clovis activity as other tool forms. Clovis sites commonly include campsites, quarries, caches, and kill sites (Collins 1995). With the exception of quarries, these sites are often buried beneath meters of sediment. Many Clovis finds, however, are single artifacts or clusters lying on the surface of deflated landscapes. A single artifact of possible-Clovis manufacture has been found at Camp Swift (Nickels 2005b:Table 6-2).

Folsom and Midland points follow Clovis in time, with Midland occurring slightly later though overlapping in certain instances with Folsom. Folsom points are exquisitely fluted, and are often found with ancient bison remains. Midland points also are extremely well made, showing fine pressure collateral flaking though without fluting. Very thin bifaces, called ultrathins, are commonly found at some Folsom campsites. These bifaces exhibit width-tothickness ratios of up to 20:1 (Root et al. 1999). Other Pleistocene fauna were extinct by this time, and Folsom peoples are frequently regarded as specialized bison hunters. Many Folsom sites occur as surface scatters, though some deeply buried deposits are known as well from areas in Bell, Goliad, Uvalde, and Williamson Counties (Collins 1995).
Late Paleoindian diagnostic artifact styles proliferate by around 10,000-9,700 years ago, perhaps as a result of dramatic changes as annual temperatures warmed and conditions gradually became wetter in the Early Holocene (Bousman 1998; Collins 1995:Table 2). The change from relatively xeric to mesic conditions was accompanied by gradual shifts in settlement mobility, subsistence practices, technological innovation, and some social practices (Bousman et al. 2004). Important point styles from this period include Wilson, Dalton, St. Mary's Hall, Golondrina, Barber, and Scottsbluff. Each of these exhibits limited distributions compared to Early Paleoindian Clovis and Folsom points, suggesting that populations associated with their production were covering smaller ranges in terms of settlement mobility. Following the end of the Pleistocene, virtually all of the large game animals that were central components of Early Paleoindian diets had become extinct, requiring a shift to expanding populations of smallerbodied animals such as deer and antelope. Bison remained important and diet breadth in general increased as indicated by recovered faunal and botanical evidence. Evidence from Central Texas indicates that groups began experimenting with technological changes such as crafting stemmed dart points, and even burying their dead at campsite locales (Bousman et al. 2002). Late Paleoindian presence at Camp Swift is somewhat problematic. The only possible evidence from this period so far comes from an Angostura point fragment recovered by Robinson (2001:122), though this type is placed by some researchers (Collins 1995) in the Early Archaic (see below).

\section{Archaic}

Distinctions between the Paleoindian and ensuing Archaic stages were established early on by scholars such as Willey and Phillips (1958:107-111), who recognized nine primary 
differences between the two periods. These initially included shifts from large animal hunting and exploitation to a variety of smaller animals, increased plant food use and gathering, increase in use of ground stone tools for processing plants, greater number and variety of chipped stone tools for apparent wood working, manufacture of corner- and sidenotched projectile points that were propelled with an atlatl, greater population stability with less residential mobility, increased reliance on organic materials for tool production, systematic burial of dead, and use of stone for cooking technologies. However, new evidence indicates that some of these transitions occurred over long periods of time (Bousman et al. 2002). The finer distinctions between Late Paleoindian and Early Archaic have become blurred, leading some (Oviatt et al. 2003) to use the term "Paleo-Archaic" to refer to the late Pleistocene-early Holocene interval. Important points for consideration when modeling this dynamic period are environmental shifts and changing climatic conditions that affected regional plant and animal species inventories. In general terms, landscapes became wetter over this interval (with severe oscillations between wet and dry throughout the Holocene), though this process was not synchronous from one region to another and effects were not the same on all local environments. The most detailed Archaic cultural chronologies for Central Texas and adjacent regions have been proposed and modified by Prewitt (1981, 1985).

\section{Early Archaic}

Given these drawn-out transitions, it is difficult to place the beginning of the Archaic with precision. Bousman et al. (2004) suggest it began around 8,000 years ago, while Collins (1995) places it from 8,400 to 8,800 years ago. Angostura points, which exhibit basal grinding distinctive of many Paleoindian point types, seem to span the transition from Late Paleoindian to Early Archaic. Weir (1976) has suggested that Early Archaic populations were small and highly mobile based on the large number of thinly distributed sites and the occurrence of diagnostic types across areas in Texas and New Mexico. However, extensive deposits from this period at sites including Wilson-Leonard (Williamson County), Gault (Bell County), Kennedy Bluffs (Bastrop County), and many others indicate that social groups converged on familiar locales during certain times of the year. Burned rock features appear, and are gradually replaced by middens (at least in some regions) as hot rock cooking techniques are more commonly applied throughout the Archaic (see Black et al. 1997). Diagnostic artifacts include split-stem dart points such as Gower, Hoxie, and Jetta. Waco Sinkers and grooved stones also appear, suggesting the use of nets as new (or at least newly identified) components of subsistence-related toolkits. Guadalupe and Clear Fork bifaces show wear patterns as gouges and adzes, indicating wood working during this time. Specialized bison hunting weaponry dating to the very end of this period is perhaps represented by Bell and Andice points and their northern counterpart, Calf Creek (Johnson and Goode 1994; Wyckoff 1995). Additionally, while not commonly found, ornamental items such as shell and drilled stone beads provide evidence for personal adornment and perhaps for the recognition of social distinctions by age, gender, or role. Elsewhere in North America, the Windover bog site in Florida contains an Early Archaic cemetery, where archaeologists have recovered the remains of at least 168 individuals (Doran 2002). In Victoria County, Texas, another multi-component cemetery with numerous Early Archaic interments has been excavated and is undergoing analysis by Robert A. Ricklis of Coastal Environments, Inc. and his team of collaborators under contract with 
the U.S. Army Corps of Engineers and project sponsor DuPont Textiles and Interiors (Ricklis 2005). Cemeteries such as these provide solid evidence for the association between nomadic groups of people and regional territories. Early Archaic presence in the Camp Swift area is so far limited; Robinson (2001:122) illustrates an Angostura point fragment and Nickels (2005b: Table 6-2) lists an Andice find (which he places in the Early Archaic rather than the Middle Archaic, as shown in Figure 2-5). Camp Swift currently lacks the kinds of extensive heated stone features (burned rock middens) found closer to and above the Edwards Plateau.

\section{Middle Archaic}

The Middle Archaic is thought to have been a time of increasing populations. Food resources like deer and acorn appear to have been hyper-abundant and provided much of the basis for seasonal residential mobility patterns (see Black 1989a). Massive middens of burned and fire-cracked rock, some with intact internal features such as pits and hearths, accumulated as a result of processing these and other resources. While many of these middens have earlier Early and Middle Archaic components underlying them, the majority dates to the Late Archaic extending into the Late Prehistoric period (Black and Creel 1997). Bison are notably absent during the middle to later parts of the Middle Archaic (Dillehay 1974), though are present in other periods. This absence corresponds with a dramatic drying of climate, described by Collins (1995:384) as "what appears from the record to have been the onset of the most xeric conditions ever experienced by humans in Central Texas.” The effects of this dry spell are significant for the prehistoric cultural record of Camp Swift. Occupants of the region would have had to adapt to these changing conditions through modifications of tool design and/or subsistence procurement technologies. Perhaps more important, though, are the impacts of this climate change on processes of sediment deposition and erosion. Currently, no cultural components at Camp Swift can be firmly dated to the Middle Archaic (see Nickels 2005b:Table 6-2, Figure 6-1). It is conceivable that landforms from this period that contained artifact materials have been lost through severe erosion as protective groundcover dried up, exposing loose sandy sediments to wind and/or episodic rainfall events. Diagnostic artifact types from this period include stemmed dart points such as Nolan, Travis, Wells, and Williams. While Prewitt (1985) describes Bulverde as Middle Archaic, Collins (1995:384) places the type at the very beginning of the Late Archaic, and the specimen reported in Nickels (2005b:Table 62) is considered a Late Archaic find; however, it probably spans the interval between these periods.

\section{Late Archaic}

The Late Archaic was a substage of additional population growth, increased use of hot-rock cooking technology, and continued diversification of point types and regionally defined settlement-subsistence patterns (Story 1985). Johnson and Goode (1994) observe influences from culture groups from the eastern part of the continent, particularly in terms of religious expression and social organization evidenced in group cemeteries (e.g., Hall 1981). Some researchers (Black 1989b) have argued that subsistence bases grew increasingly diverse, referred to as broad spectrum, though with reduced emphasis on acorns. Bison disappeared again from the Central Texas region (Dillehay 1974). The large number of Late Archaic diagnostic points is partly a reflection of the length of this period compared with the preceding Middle Archaic. Styles include Pedernales, Montell, Castroville, and others. The presence of Yarbrough in project 
areas near Camp Swift is likely to be evidence of influence from eastern parts of the state. At Camp Swift, illustrated types include Ensor, Frio, and Pedernales (Lehman et al. 2003; Robinson 2001).

\section{Late Prehistoric}

The Late Prehistoric represents an important and highly dynamic transition out of "Archaic" ways of life to substantially changed subsistence-related technologies and perhaps even patterns of social movements and interactions across the landscape. Divided into two phases (Jelks 1962) termed Austin and Toyah (Prewitt 1981), the Late Prehistoric is defined by distinctive traits that include the adoption of bow-and-arrow technology, ceramic manufacture, and, in some regions, agricultural practices. As Collins (1995:385) notes, this last trait was of only minor importance across some parts of the state. The Austin phase is commonly seen as merely a continuation of the Late Archaic (Johnson and Goode 1994). The most important changes are the appearance of small arrow point types such as Edwards and Scallorn, indicating a shift away from use of the atlatl. These types replace the smaller dart point forms that trend from Late Archaic into the Austin phase, including Darl, Ensor, Frio, Gary, Kent, and others. Burned rock middens are occasionally found associated with these dart point forms, as well as Edwards and Scallorn points (e.g., Houk and Lohse 1993). Ground and pecked stone artifacts for plant processing, which appear much earlier in the Archaic, are relatively common by this time. Dillehay (1974) has noted that bison are not present in the region during the Austin phase, though additional work (Huebner 1991) has suggested that bison might only have been reduced in number and distribution, not entirely absent. Perhaps two of the most important developments at this time include the introduction of bone-tempered pottery along the Upper Gulf Coast and East Texas (Story 1985; Story et al. 1990) as early as AD 300-500, and evidence for social conflict. A number of individual burials dating to the Austin phase have been exhumed that show signs of arrow point penetration (e.g., Meissner 1991; Prewitt 1974; see Black 1989a), suggesting that populations had increased to the point where regional territorial disputes emerged over available resources.

Perdiz points, characterized by long contracting stems and flaring barbed shoulders, appear in the archaeological record of Central Texas and nearby areas around AD 1200. Kelly (1947a, 1947b) associated these with what he called the Toyah Focus, and they have remained the central element of material assemblages from the later portion of the Late Prehistoric. Prismatic blades, blade cores, and scraperson-blades occur and are thought to be parts of specialized Toyah bison hunting and processing toolkits (Black and McGraw 1985; Huebner 1991; Ricklis 1994). More importantly in terms of the social composition of Toyah groups, though, is the wide variety of ceramic styles and influences that are seen across Toyah assemblages. Some vessels found at sites from this period evidence Caddo-style decorations, while others are coated or decorated with asphaltum from the Texas Gulf Coast. Still other design elements are from West Texas and show Jornada Mogollon influences. Johnson (1994) has argued that Toyah is the material remains of a single group that sprawled across these vast areas, while Ricklis (1994) has described it more as a constellation of traits that moved through relatively stable regional populations (a techno-complex). More recently, John Arnn (2005) has considered the drift of ceramic styles into and out of Toyah "core areas" as signifying the movements of small groups of people who moved between different populations established in these regions. Perdiz 
points, long thought to be at the core of Toyah material culture, are also noted in much later contexts, including an example made of glass recovered from American Indian neophyte residential contexts at the San Antonio de Valero mission in San Antonio (e.g., Lohse 1999:268). The relationships of Toyah peoples with their regional neighbors and their lingering material record are among the more intriguing topics of study in late Texas prehistory.

\section{Historic Period: 1500-1950}

Beginning with the entry of Europeans into Texas in the early to mid-1500s, encounters between indigenous groups and "new" settlers were increasingly common. As part of New Spain, Spanish priests have provided perhaps the best and most complete accounts of early history in the area extending from south of San Antonio into Northern Mexico and up to East Texas. Entradas, or forays from established forts and missions, into the project area were recorded in 1691, 1709, and 1714. El Camino Real, linking Spanish settlements in San Antonio and Nacogdoches, crossed the Colorado River near present-day Bastrop. In 1804, the Spanish built a small fort, Puesta de Colorado, at the Colorado River crossing in an attempt to protect their territory from French and early United States settlers (Leffler 2001:14).

By 1827, Mexico achieved independence from Spain and opened the region of what is today South Texas, extending north into Bastrop County to settle. Stephen F. Austin's "Little Colony," located along the Colorado River, was an intended destination, with the town of Bastrop platted in 1832. Clashes with American Indians, though, deterred large numbers of immigrant settlers from entering the area. Texas Rangers provided better protection after Texas had secured independence from Mexico in 1836, and the Republic of Texas offered generous grants as an incentive for people to move into the new settlement. In many cases, Rangers themselves attacked tribes in the region in an effort to clear the path for pioneers and to ensure the safety of new settlements (Leffler 2001:14). While a treaty was signed with the Comanche in 1845, violent encounters continued between new arrivals and indigenous peoples (Wilbarger 1985). As railroads entered the region beginning in the 1870s, more people arrived and new towns appeared, such as Elgin, Sayersville, and McDade. Gradually, tracts of land were cleared for farming, especially corn and cotton.

Among the most prominent early settlers and farmers of the Camp Swift area was Antoine Aussiloux, a French immigrant who became a naturalized U.S. citizen in 1875. Antoine came to the United States with his brother A. Cologne, and in the 1870s was living in Bastrop County as a stonemason. In 1876, Aussilloux bought 60 acres on the north bank of Big Sandy Creek with a partner, Frank Gorton, to establish a winemaking business. Aussilloux is perhaps the most notable early settler of Camp Swift; remains of his industry include the ruined limestone cellar of his two-story house (recorded as site 41BP138), the Scott Falls dam across Spring Branch (also called Scott Falls Creek) crafted of hand-chiseled limestone and sandstone blocks, and remnants of an irrigation system that carried water from the dam (Nickels and Lehmann 2004b:72-89) to his grape fields located almost a mile distant. Upon the passage of the Prohibition amendment in 1919, Aussilloux was forced to close his winery operation. He was found dead in his front yard by a neighbor in 1924, and soon after local authorities burned his property and remaining buildings because of their unsanitary condition. The homestead remained in this condition until 1942 when Camp Swift was created and U.S. Army officials acquired the 100 -acre estate for \$477 (Leffler 2001:18). 
In addition to the Aussilloux winery, another significant early business in the area now occupied by Camp Swift was the Sayers lignite mine. Operated by Frank Dennison under a lease with Mrs. Mary C. Young, the Sayers Mine extracted over 200 railroad cars of lignite a year between 1915 and about 1924, when the operation was damaged by fire. Dennison rebuilt his operation, but closed for good in 1928 after a second fire. Stipulations of the Dennison-Young lease called for the removal of all buildings and improvements from the property when and if the mine was no longer active. Remains from this operation at Camp Swift include sump ponds corresponding with old mining shafts, surface scatters of artifacts, spoil piles, and a cemetery for Mexican workers (41BP170) who died while working at the mine (Leffler 2001).

Near the outset of World War II in 1940, the United States Army received a proposal from business and civic leaders in Austin, Bastrop, Elgin, and nearby smaller towns to acquire land for the construction and operation of a military training base near Bastrop. The area was deemed ideal for a number of reasons, including the relatively low fertility and agricultural productivity of the sandy soils; existing nearby highways, rail lines, and power and gas lines; abundant well water; and the projected low cost per acre of acquiring the necessary property (Leffler 2001:25). After agreeing to the initial proposal, construction of the camp was underway by January 1942. A total of 55,906 acres was originally acquired, mostly through condemnation proceedings against the land owners. Leffler (2001:25) reports that as many as 350 families were displaced by the camp development. Officially commissioned in 1942, Camp Swift was named after General Eben Swift, a distinguished veteran of the Spanish-American War and World War I (Leffler 2001:26). By 1943, Camp Swift was the largest military training facility in Texas. Its construction had notable impacts on the local economy as well, providing jobs for over 18,000 laborers. As the war drew to a conclusion, Camp Swift's role gradually changed from military training to a "separation point" for servicemen returning home (Leffler 2001:29). Buildings were gradually decommissioned and given away to local schools, and acreage sold off to either State agencies or in some cases to previous landowners. By the mid-1950s, very little remained of the original cantonment area and training facility that had accommodated as many as 300,000 soldiers during World War II. 


\section{Chapter 3}

\section{Methods and Results of Investigations}

Archaeologists from CAS tested eight sites in the Camp Swift military installation by excavating backhoe trenches in early October of 2005. These sites had been discovered in earlier surveys, but all were revisited and reassessed by CAS in 2002-2003 (Nickels and Lehman 2004a). During the 2005 fieldwork, each trench was carefully excavated in levels approximately 10-20 cm deep. Where sediments were more compact, the levels were smaller. Some mixing of artifacts from upper or lower elevations was unavoidable because the teeth on the backhoe bucket invariably took deeper "bites" than what was removed in each bucket. In most instances, the backhoe operator would excavate a segment of the trench between four and five meters in length to its bottom elevation, resituate the backhoe, and then excavate another conjoining length of the trench, resulting in trenches that averaged between eight and ten meters long that were excavated in two sections. When features were noted, archaeologists would halt the excavation of that part of the trench, leaving (as much as possible) the sandy sediments under the feature pedestalled in place. Photographs were taken of features and/or their disturbed contents, and provenience and context information was documented on feature recording forms. Each trench was closely monitored so that artifacts appearing in trench bottoms could be identified. Additionally, all buckets of earth were inspected for artifacts when they were removed from the trench, but sediments were not screened. The frequency and approximated depths of artifacts observed from each trench were recorded in a field book. Following these procedures allowed archaeologists to record the approximate depths, and in some cases distributional patterns, of most of the cultural materials that were present in each trench.

After all trenches were excavated, profile descriptions and geomorphology were recorded on standard field forms. In the field, CAS archaeologists described the vertical profiles by sediment zones. A zone is a distinctive and homogeneous sedimentary unit with a recognizable top and bottom. Sediment color, as compared to a Munsell chart, texture, soil structure, mottling, calcium carbonate and manganese accumulations, natural or cultural inclusions of all sorts, evidence for disturbance, and zone boundaries were systematically described. CAS assigned soil horizon designations to sediment zones in the field or later in the lab. Soil horizon and depositional unit designations follow the Soil Survey Staff (1993) classifications. The most commonly encountered soil horizons from the surface down were: decomposing leaf litter and other organic matter composing $\mathrm{O}$ horizons; organic, enriched, and darker A horizons; depleted and bleached E horizons; mineral enriched B horizons; and truncated, heavily weathered and clay enriched bedrock 2Bt horizons. The locations of each backhoe trench were recorded by Global Positioning 
System (GPS) so that they could be added to existing site maps developed by CAS showing site boundaries and the locations of previous excavations. Temporally diagnostic artifacts were collected, and will be curated at the Texas Archeological Research Laboratory (TARL) at The University of Texas at Austin.

\section{BP105}

This site was first recorded by Skelton and Freeman (1979). Nickels and Lehman (2004b:31) describe it as an open prehistoric campsite, situated on a lower terrace just west of the confluence of a spring-fed stream and Big Sandy Creek. Ground cover is very dense, consisting of heavy grasses and mixed weeds. Wooded areas containing oaks and junipers surround the open landform, particularly following along the adjacent waterways. Soils identified on this landform include Sayers fine sandy loam. Historic debris has been noted on the surface, and a possible irrigation channel runs nearby that dates to the late1800 s and early-1900s grape cultivation by the Aussilloux winery. Wild grapevines still cover parts of the site.

Skelton and Freeman (1979) observed a one-meter-long rock hearth exposed in a channel cutbank, approximately $50 \mathrm{~cm}$ below the surface (cmbs). In a following survey by CAS in 2002, shovel tests (STs) yielded both historic and prehistoric artifacts as deep as 100 cmbs. Nineteen shovel tests were excavated at the site, most stopping at 100 cmbs. One
(ST 6) went as deep as $110 \mathrm{cmbs}$, while three others (STs 17, 18, and 19) reached between 50 and $60 \mathrm{cmbs}$ and were stopped either at the clay substratum or at the water table. Historic artifacts included historic pottery, glass, and a bullet casing from between $70 \mathrm{cmbs}$ and ground level. Prehistoric remains consisted of both small ( $<1$ inch) and large ( $>1$ inch) fire-cracked rock, utilized flakes, interior and exterior flakes, other non-flake debitage, and a charred nut hull.

Four backhoe trenches (BHTs) were excavated in the current investigation near CAS STs 3, 8, and 12 and between STs 11 and 14 on the basis of artifacts recovered from those probes (Figures 3-1, 3-2). Backhoe trench profiles were described for each and are provided below followed by a photograph of the profile described (Figures 3-3 to 3-7).

FIGURE 3-1. REDACTED

Figure 3-1. Map of 41BP105 showing locations of backhoe trenches and 2002-2003 shovel tests (adapted from Nickels and Lehman 2004b: Figure 4-14). 


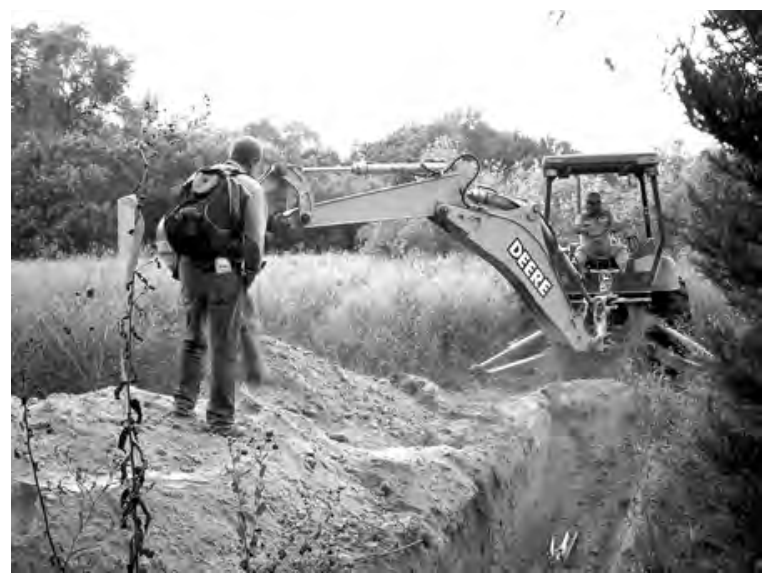

Figure 3-2. CAS archaeologist David Payton monitoring backhoe trenching at 41BP105.

Most of the sediments exposed in the backhoe trenches displayed thick, sandy A-B horizons. In BHT 1 a 2Bt horizon was encountered at 198 cmbs, but in BHT 2, BHT 3 and BHT 4 clay lamella were encounter within sandy deposits at 130,80 , and $130 \mathrm{cmbs}$, respectively, in the lowest soil zones. No stratigraphic breaks were observed above the $2 \mathrm{Bt}$ horizon.

\section{Description of sediments in BHT 1 (Profile 24) at 41BP105}

Zone 1: 0-18 cmbs, brown (10YR5/3) loose fine sandy loam, moderate grass cover, common rootlets, clear smooth lower boundary, Ap horizon.

Zone 2: 18-100 cmbs, pale brown (10YR6/3) massive friable fine sandy loam, common rootlets, few roots, diffuse smooth, clear smooth lower boundary, B1 horizon.

Zone 3: 100-140 cmbs, very pale brown (10YR7/3) friable fine sandy loam, gradual smooth lower boundary, B2 horizon.

Zone 4: 140-198 cmbs, very pale brown (10YR7/3) massive friable fine sandy loam, few roots and rootlets, $<5$ percent faint fine yellowish brown 10YR5/6 mottles, abrupt smooth to wavy lower boundary, B3 horizon.

Zone 5: 198+ cmbs, Strong brown to grayish brown (7.5YR4/6 to 10YR5/2) firm medium sandy clay loam, lower boundary not observed, 2Bt horizon.

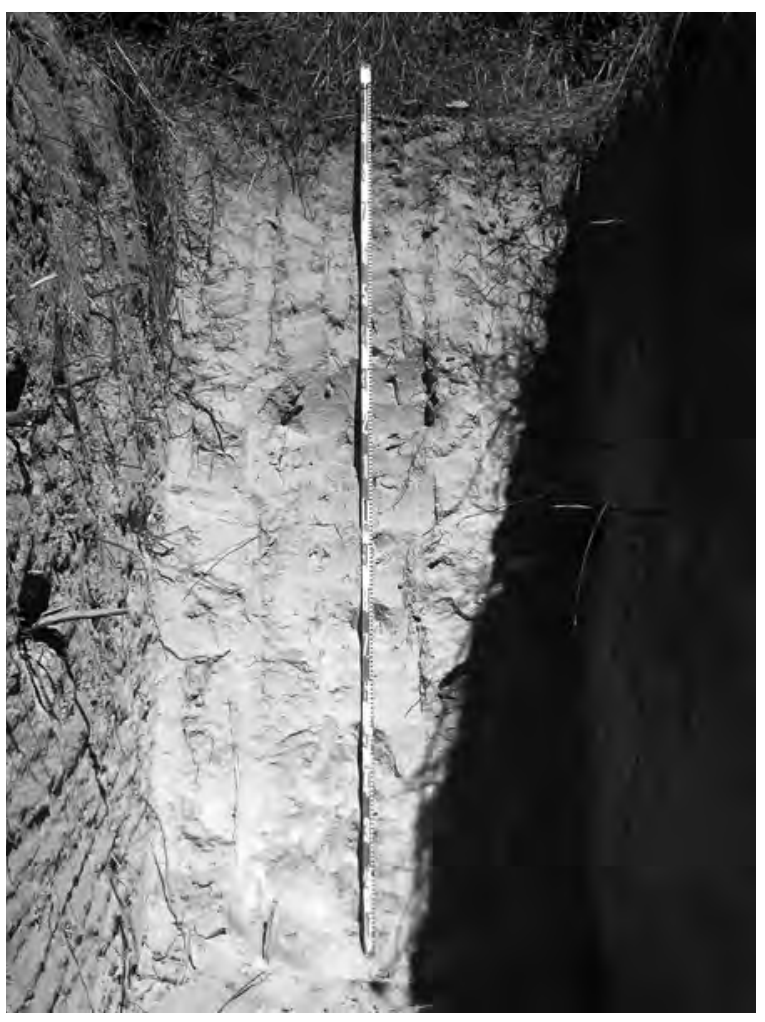

Figure 3-3. Profile 24 in BHT1 at 41BP105.

\section{Description of sediments in BHT 2 (Profile 25) at 41BP105}

Zone 1: 0-75 cmbs, brown (10YR5/3) massive friable fine sandy loam, dense grass and weed cover on surface, common rootlets in upper 5 $\mathrm{cm}$, few rootlets below, fire-cracked rock at 69 $\mathrm{cm}$, clear smooth lower boundary, B1 horizon.

Zone 2: 75-110 cmbs, very pale brown (10YR7/3) friable fine sandy loam, few rootlets, 


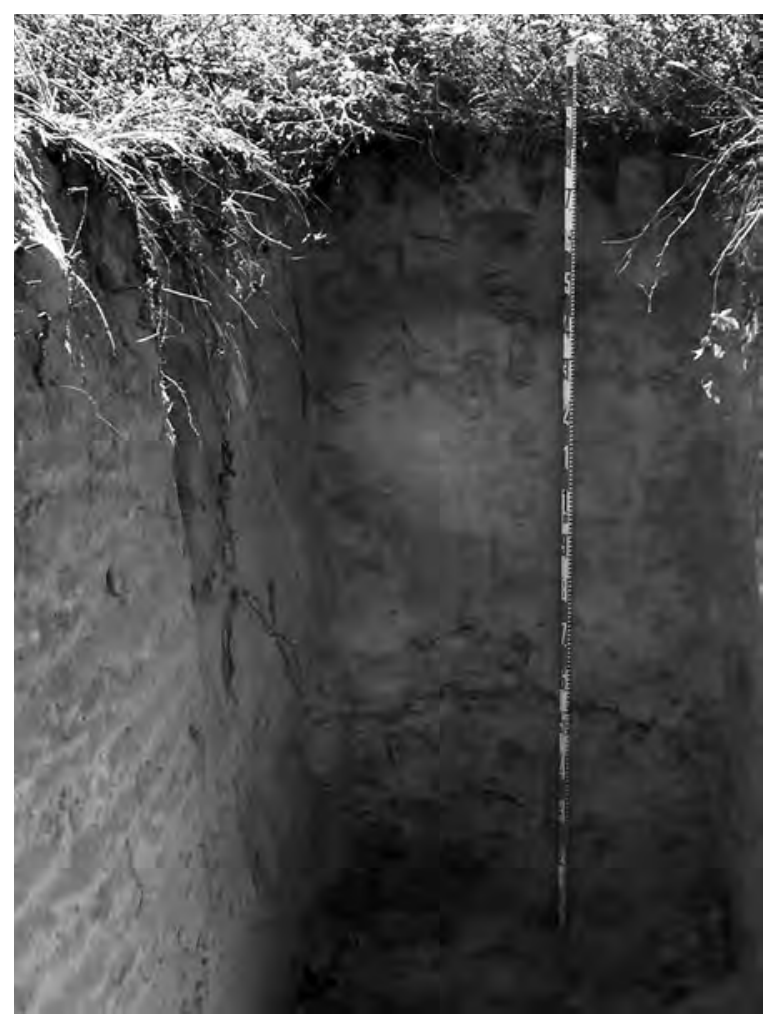

Figure 3-4. Profile 25 in BHT 2 at 41BP105.

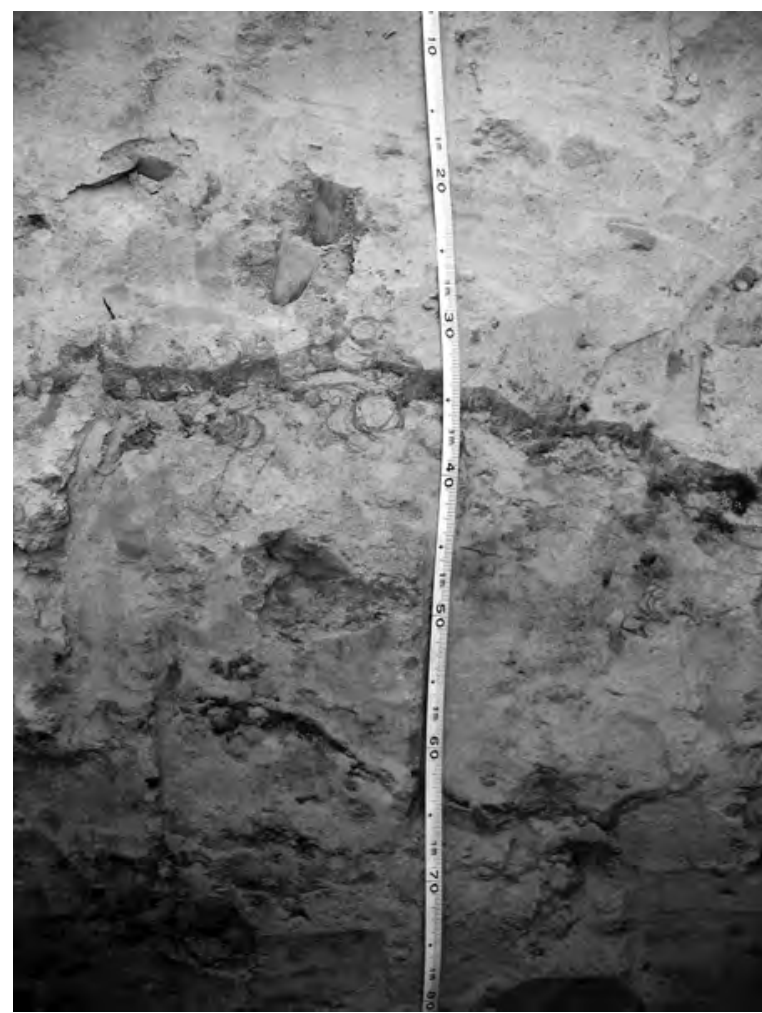

Figure 3-5. Zone 3 of Profile 25 in BHT2 at 41BP105. fire-cracked rock at $100 \mathrm{~cm}$, gradual smooth lower boundary, B2 horizon.

Zone 3: 110-130 cmbs, very pale brown (10YR7/4) friable fine sandy loam, yellowish brown (10YR5/4) clay bodies, amorphous shapes round-oblong possibly representing insect burrows, abrupt irregular lower boundary, Bt1 horizon.

Zone 4: $130-190+$ cmbs, very pale brown (10YR7/3) massive, friable fine sandy loam, dark yellowish brown (10YR4/6) clay lamellae up to $20 \mathrm{~mm}$ thick, some clearly burrowed and turbated, lower boundary not observed, Bt2 horizon.

\section{Description of sediments in BHT 3 (Profile 27) at 41BP105}

Zone 1: 0-3 cmbs, decomposed leaf litter, twigs and root mat, abrupt wavy lower boundary, $\mathrm{O}$ horizon.

Zone 2: 3-16 cmbs, pale brown (10YR6/3) loose fine sandy loam, common rootlets, few insect burrows, abrupt wavy lower boundary, A horizon.

Zone 3: 16-48 cmbs, pale brown (10YR6/3) friable fine sandy loam, few rootlets, roots, and insect burrows, clear smooth lower boundary, AB horizon.

Zone 4: 48-80 cmbs, light yellowish brown (10YR6/4) friable fine sandy loam, few roots and rootlets, clear smooth lower boundary, B horizon.

Zone 5: 80-190+ cmbs, light yellowish brown (10YR6/4) massive sandy loam, few rootlets, strong brown $(7.5 \mathrm{YR} 4 / 6)$ clay lamellae up to $3 \mathrm{~mm}$ thick, lower boundary not observed, Bt horizon. 


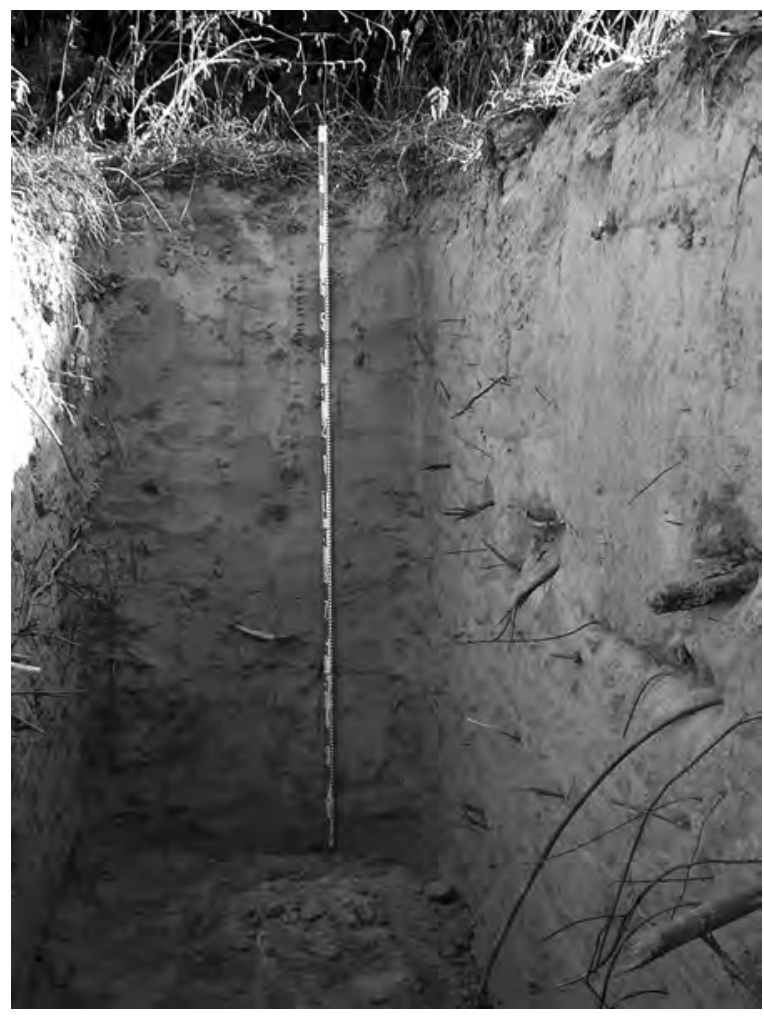

Figure 3-6. Profile 27 in BHT 3 at 41BP105.

\section{Description of sediments in BHT 4 (Profile 26) at $41 B P 105$}

Zone 1: 0-75 cmbs, brown (10YR5/3) massive friable fine sandy loam, dense grass and weed cover on surface, common rootlets in upper 5 $\mathrm{cm}$, few rootlets below, fire-cracked rock at 69 $\mathrm{cm}$, clear smooth lower boundary, A horizon.

Zone 2: 75-110 cmbs, very pale brown (10YR7/3) friable fine sandy loam, few rootlets, firecracked rock at $100 \mathrm{~cm}$, gradual smooth lower boundary, E horizon.

Zone 3: $110-130$ cmbs, very pale brown (10YR7/4) friable fine sandy loam, yellowish brown (10YR5/4) clay bodies, amorphous round-oblong shapes insect burrows, abrupt irregular lower boundary, Bt1 horizon.

Zone 4: 130-190+ cmbs, very pale brown (10YR7/3) massive friable fine sandy loam, dark yellowish brown (10YR4/6) clay lamellae

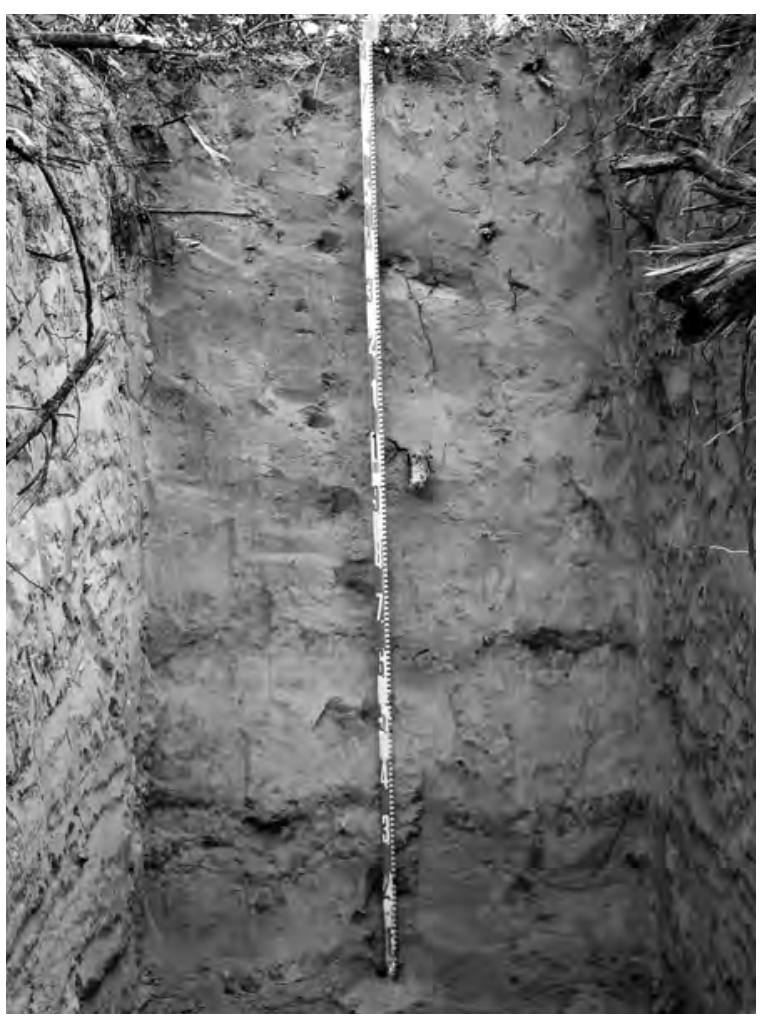

Figure 3-7. Profile 26 in BHT 4 at 41BP105.

up to $20 \mathrm{~mm}$ thick, some clearly burrowed and turbated, lower boundary not observed, Bt2 horizon.

The presence of artifacts and cultural material including charcoal from as high as 85 cmbs to approximately $100-120$ cmbs from three of the four trenches reveals that cultural deposits are found at this site at and below depths reached by shovel tests (Figure 3-8). Additionally, the consistent elevations of these items suggest the possibility of an intact cultural component that covers the area sampled by BHTs 1,3 , and 4 (Table 3$1)$. The piece of petrified wood is considered to have been brought onto the site by human agents; no other stones, cobbles, or gravels were observed in this trench at this depth that would indicate a geologic mechanism of deposition for the item. 


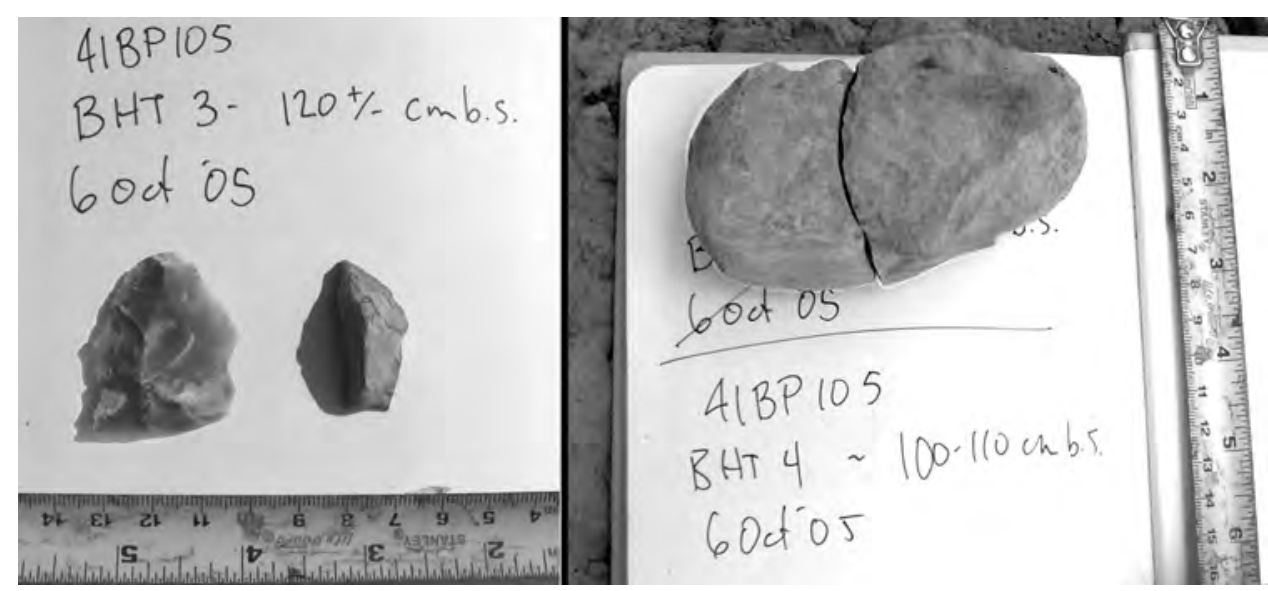

Figure 3-8. Artifacts recovered from 41BP105 at depths of between 100 and 120 cmbs. Items include a large interior flake and spall from a fire-cracked rock (left), and a large heat-fractured but refitting stone (right).

Table 3-1. Approximate depths of artifact recovery from backhoe trenches at 41BP105. When no depth could be recorded, artifact depth is listed as "unknown.”

\begin{tabular}{|c|c|c|c|c|c|c|}
\hline Trench & $\begin{array}{c}\text { Bottom } \\
\text { Elevation } \\
\text { (cmbs) }\end{array}$ & $\begin{array}{c}\text { Clay } \\
\text { Reached? }\end{array}$ & $\begin{array}{c}\text { Debitage } \\
\text { (cmbs) }\end{array}$ & $\begin{array}{c}\text { Charcoal } \\
\text { (cmbs) }\end{array}$ & $\begin{array}{c}\text { FCR } \\
\text { (cmbs) }\end{array}$ & $\begin{array}{c}\text { Others } \\
\text { (cmbs) }\end{array}$ \\
\hline BHT 1 & 190 & no & 85 & - & unknown & - \\
\hline BHT 2 & 170 & no & - & - & unknown & petrified wood at 60 \\
\hline BHT 3 & 190 & yes & $45,120-130$ & 100 & 120,1 unknown & - \\
\hline BHT 4 & $160-170$ & yes & 10 & - & $100-110$ & - \\
\hline
\end{tabular}

Based on the information recovered from this site, the period(s) of occupation are unknown. Artifacts reflect a generalized range of activities that can be associated with domestic/residential occupation. In this regard, the original assessment of the site as an open campsite (see Table 1-1) is supported. In spite of the abundance of artifacts observed here, since no features were recorded the site is not presently considered potentially eligible for listing to the NRHP, and no further work is recommended. 


\section{BP111}

This site is described by Nickels and Lehman (2004b:33-36) as an open prehistoric campsite with fire-cracked rock and a lithic scatter. It sits on heavily wooded ridgeslopes overlooking an intermittent upper tributary of McLaughlin Creek. Mature oaks with intermixed junipers provide a shady canopy that effectively blocks most sunlight from reaching the ground. Patilo complex soils cover the site.

Skelton and Freeman (1979) originally recorded the site and observed two firecracked rock hearths in a cutbank profile at 25 and 35 cmbs, respectively, along with a few flakes. A 1x1-m, handexcavated test unit in the original fieldwork recovered a core fragment, abundant fire-cracked rock (over 100 pieces), and numerous pieces of debitage. In the CAS 20022003 revisit and assessment, 40 shovel tests were excavated in parts of the site designated Area A and Area B (Figure 3-9). A number of artifacts were recovered including fire-cracked rock, interior (cortex-free) and exterior (cortical) debitage, and utilized and retouched flakes. The CAS revisit exposed deep sand deposits of over 100 cmbs; several artifacts were recovered from these lower depths (Nickels and Lehman 2004b:Table 4-6) and some shovel probes did not reach the clay substratum. A fire-break trail has recently been cut through part of the site, exposing a hearth feature at the edge of the intermittent tributary (Figure 3-10).

Five backhoe trenches were excavated at 41BP111 near CAS STs 10, 18, 32, and 37. Backhoe trench profiles were described for each and are provided below followed by a photograph of the profile described (Figures 3-11 to 3-16). These descriptions document the presence of a thick sandy A-E-B pedon sequence overlaying a heavily weathered clayey (2Bt) horizon at 128, 120, 140, and 95 cmbs in BHTs 1, 3, 4 and 5. No stratigraphic breaks were observed in the sandy soil horizons overlying the $2 \mathrm{Bt}$ horizon.

FIGURE 3-9. REDACTED

Figure 3-9. Map of 41BP111 showing locations of backhoe trenches and 2002-2003 shovel tests (adapted from Nickels and Lehman 2004b: Figure 4-16). 


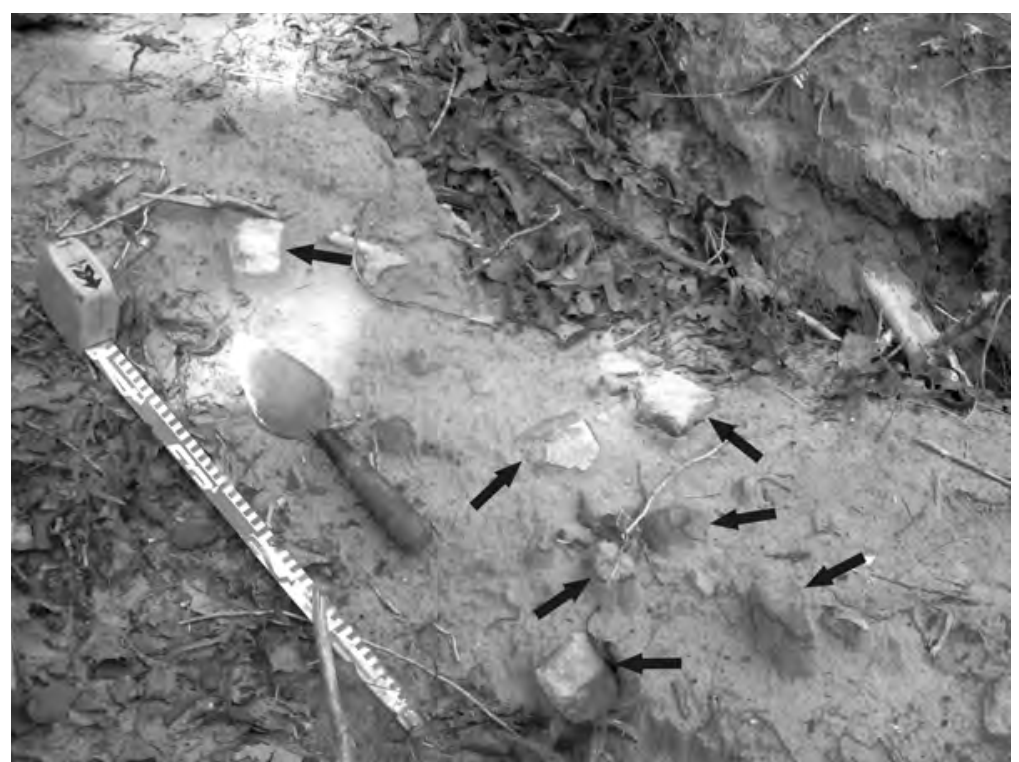

Figure 3-10. Disturbed hearth of fire-cracked rock eroding out of the ridge at the top of an intermittent tributary, which was exposed in a fire break trail. Arrows indicate fire-cracked rocks.
Zone 5: 121-128 cmbs, reddish yellow to strong brown(7.5YR6/6 to 7.5YR6/6) slightly firm fine to medium sandy loam, clear wavy lower boundary, Bt horizon.

Zone 6: 128-150+ cmbs, grayish brown (2.5Y 5.5/2) very firm medium sandy clay loam with coarse strong subangular to angular blocky structure, 20 percent red (2.5YR5/8) to reddish yellow (5YR6/8) prominent medium mottles that increase in size and density down profile, some clay films on ped faces, lower boundary not observed, 2Bt horizon.

\section{Description of sediments in BHT 1 (Profile 14) at 41BP111}

Zone 1: 0-5 cmbs, brown (10YR5/3) loose sandy loam, sporadic leaf litter, few rootlets, abrupt wavy lower boundary, A1 horizon.

Zone 2: 5-10 cmbs, pale brown (10YR6/3) slightly friable fine sandy loam, common rootlets, few roots and insect burrows, abrupt irregular to wavy lower boundary, A2 horizon.

Zone 3: 10-105 cmbs, very pale brown (10YR7/3) slightly friable massive fine sandy loam, few roots and rootlets, flake at $34 \mathrm{~cm}$, fire-cracked rock at $50 \mathrm{~cm}$, few ( $<1$ percent) ironstone pebbles up to $14 \mathrm{~mm}$, gradual lower boundary, E horizon.

Zone 4: 105-121 cmbs, very pale brown (10YR4/7) friable fine sandy loam, few fine faint to distinct yellowish brown (10YR5/6) mottles that gradually increase in size and frequency down profile, clear smooth lower boundary, B horizon.

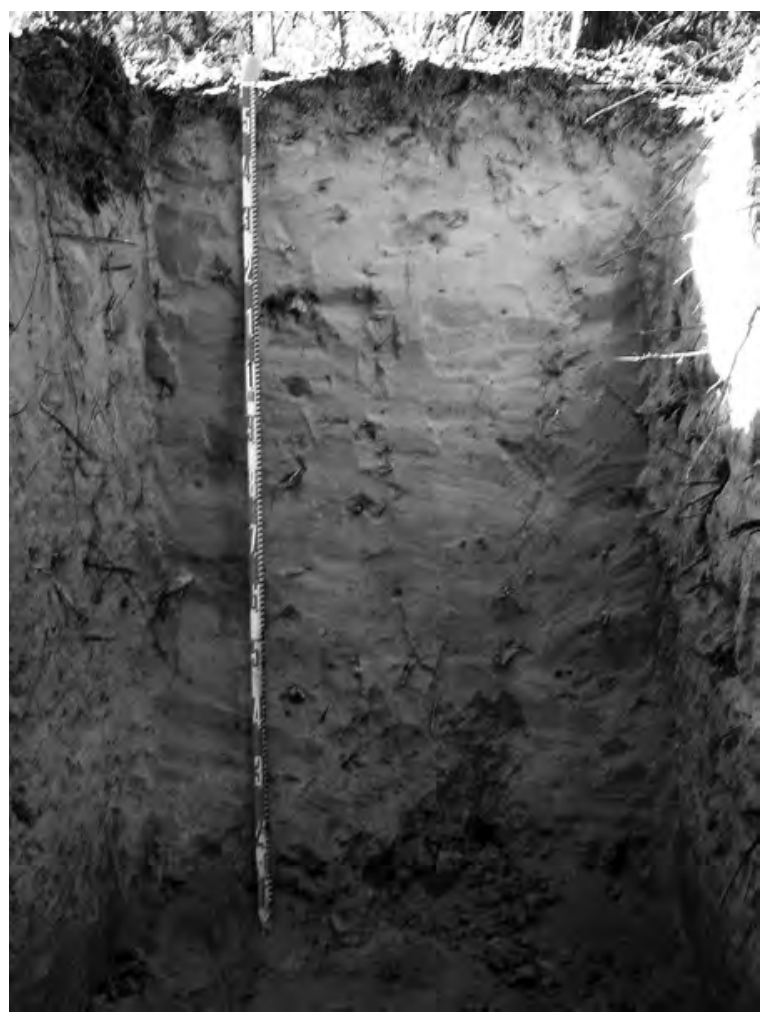

Figure 3-11. Profile 14 in BHT 1 at 41BP111. 


\section{Description of sediments in BHT 2 (Profile 15) at 41BP111}

Zone 1: 0-3 cmbs, dense leaf litter, decomposing twigs and rootlets, abrupt lower boundary, $\mathrm{O}$ horizon.

Zone 2: 3-16 cmbs, light brownish gray (10YR6/2) loose fine sandy loam, very many rootlets, few roots, clear smooth lower boundary, A1 horizon.

Zone 4: 25-55 cmbs, very pale brown (10YR7/3) friable fine sandy loam, few roots, rootlets, and insect burrows, clear smooth lower boundary, E horizon.

Zone 5: 55-135 cmbs, pinkish gray (7.5YR7/2) friable massive fine sandy loam, few roots, rootlets, and ironstone pebbles up to $3 \mathrm{~cm}$, clear wavy lower boundary, B horizon.

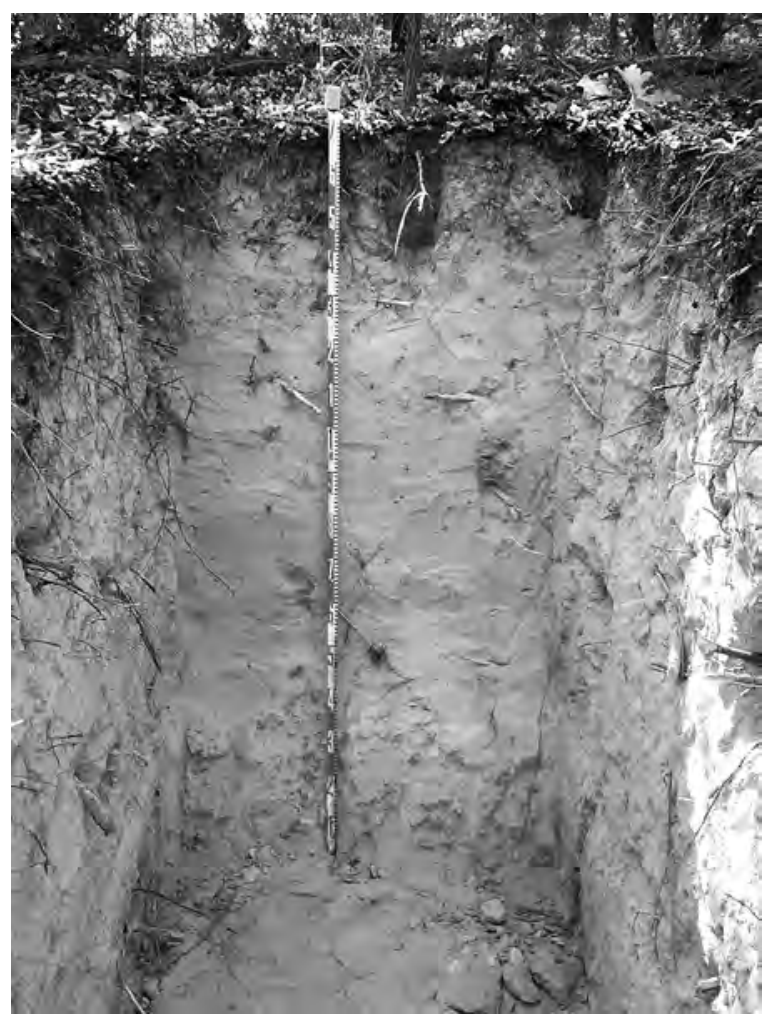

Figure 3-12. Profile 15 in BHT 2 at 41BP111.
Zone 6: $135-170+$ cmbs, very pale brown (10YR7/2.5) firm medium to fine sandy loam, coarse medium subangular blocky structure, few roots, yellowish brown (10YR5/6) mottles that increase in distinctness and frequency down profile, lower boundary not observed, Bt horizon.

\section{Description of sediments in BHT 3 (Profile 16) at 41BP111}

Zone 1: 0-5 cmbs, grayish brown (10YR5/2) friable to loose fine sandy loam, dense leaf litter, decomposing twigs on surface, abundant rootlets, abrupt smooth lower boundary, A1 horizon.

Zone 2: 5-11 cmbs, light brownish gray (10YR6/2) loose fine sandy loam, common rootlets, few roots, abrupt smooth lower boundary, A2 horizon.

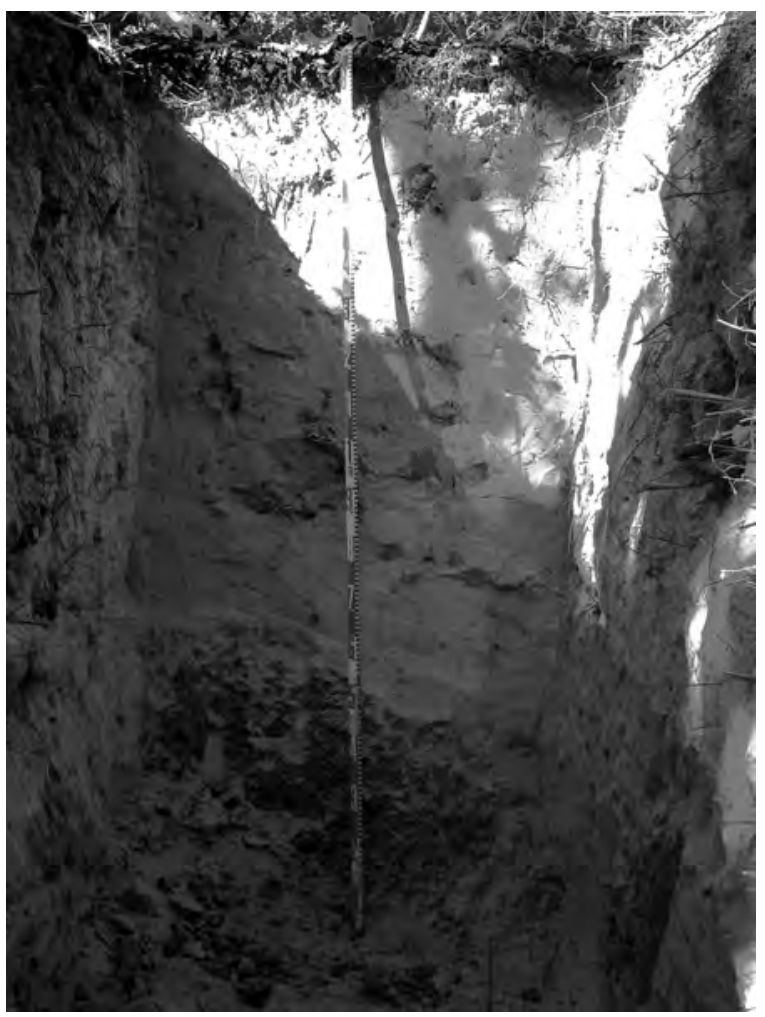

Figure 3-13. Profile 16 in BHT 3 at 41BP111. 
Zone 3: 11-20 cmbs, light gray (10YR6.5/2) friable fine sandy loam, few roots, rootlets, and insect burrows, clear smooth lower boundary, AE horizon.

Zone 4: 20-95 cmbs, light gray (10YR7/2) massive friable fine sandy loam, few roots, rootlets, and insect burrows, clear smooth lower boundary, E horizon.

Zone 5: 95-150 cmbs, very pale brown (10YR8/2) massive friable fine sandy loam, few thin $(\leq 1 \mathrm{~mm})$ soil lamellae, clear smooth lower boundary, B1 horizon.

Zone 6: 120-190 cmbs, very pale brown (10YR8/2) massive friable to firm fine sandy loam, fills a depression caused by dramatic slope in 2Bt horizon that is $40 \mathrm{~cm}$ in diameter; within Zone 6 there are blocks of Bt clay peds (medium sandy clay loam) that are brown (7.5YR 5/4) very firm and approximately 13 $\mathrm{cm}$ in diameter, clear smooth lower boundary, B2 horizon.
Zone 7: 190+ cmbs, yellowish red (5YR5/6) very firm medium sandy clay loam, medium moderate subangular to angular blocky, few roots and rootlets, thin clay films on some ped faces, lower boundary not observed, $2 \mathrm{Bt}$ horizon.

\section{Description of sediments in BHT 4 (Profile 18) at $41 B P 111$}

Zone 1: $0-5$ cmbs, brown (10YR5/3) loose fine sandy loam, moderate leaf litter, common rootlets, abrupt smooth to wavy lower boundary, A horizon.

Zone 2: 5-11 cmbs, pale brown (10YR6/3) loose fine sandy loam, common rootlets, few insect burrows, abrupt smooth wavy lower boundary, AB horizon.

Zone 3: 11-25 cmbs, light brownish gray (10YR6.5/2) friable sandy loam, few roots and rootlets, clear smooth lower boundary, B1 horizon.

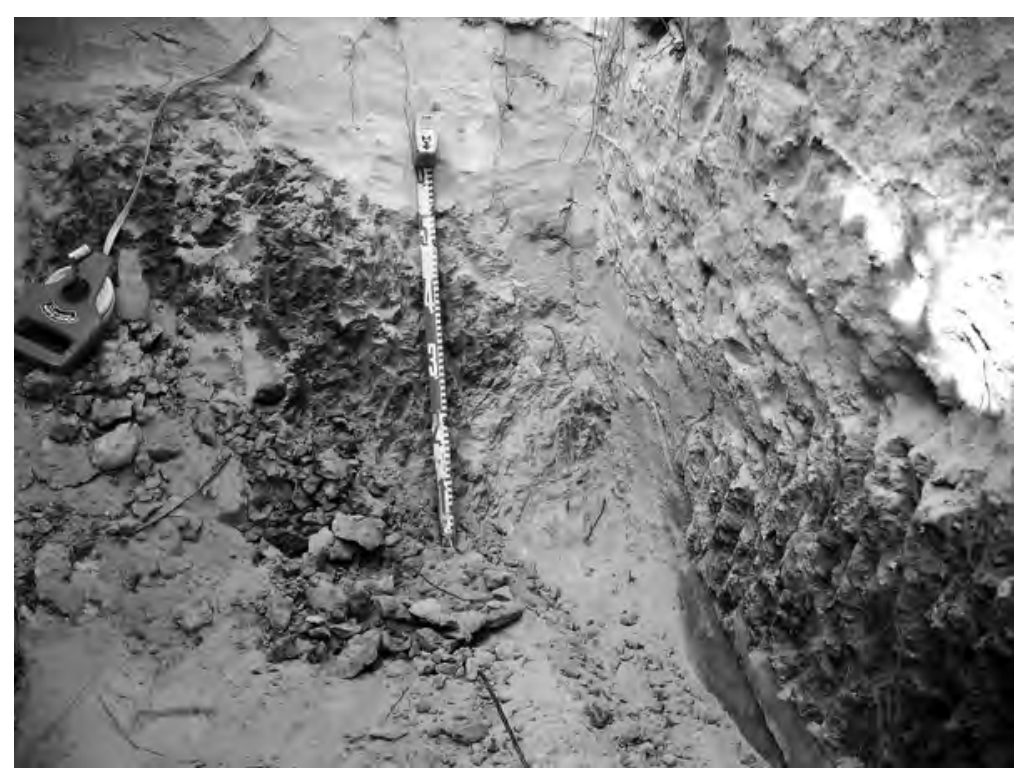

Figure 3-14. Zones 6 and 7 of Profile 16 in BHT3 at 41BP111.
Zone 4: 25-90 cmbs, light gray (10YR7/2) massive friable fine sandy loam, few roots and rootlets, rare ironstone concretions and chert, gradual smooth lower boundary, B2 horizon.

Zone 5: 90-130 cmbs, light gray (10YR7/2) friable fine sandy loam, few roots and rootlets, rare ironstone concretions and chert pebbles, few very pale brown (10YR8/2) 1-2 mm silt lamellae, clear smooth lower boundary, B3 horizon.

Zone 6: 130-140/170 cmbs, very pale brown (10YR7/3) slightly 


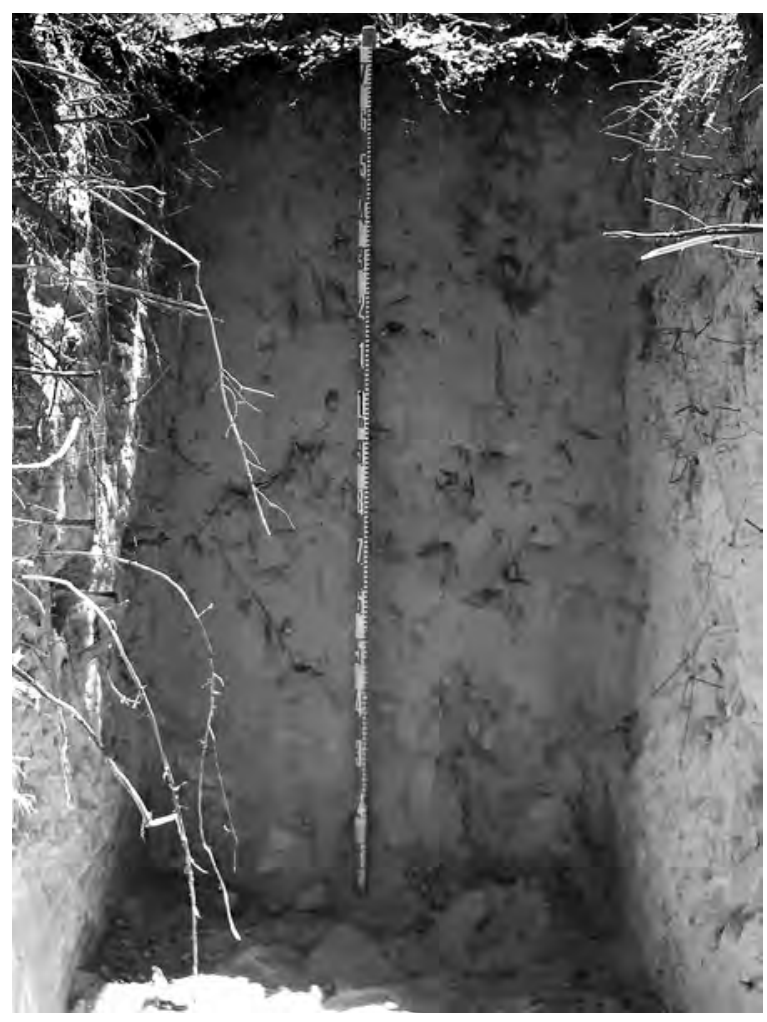

Figure 3-15. Profile 18 in BHT 4 at 41BP111.

firm sandy loam, few roots and ironstone concretions and chert cobbles, clear smooth lower boundary, B4 horizon.

Zone 7: 140/170+ cmbs, yellowish red (5YR5/6) firm medium sandy clay loam, lower boundary not observed, 2Bt horizon.

\section{Description of sediments in BHT 5 (Profile 17) at 41BP111}

Zone 1: $0-3$ cmbs, dense leaf litter, twigs and decomposing organic matter, abrupt smooth to wavy lower boundary, O horizon.

Zone 2: 3-15 cmbs, brown (10YR5/3) loose fine sandy loam, common roots and rootlets, clear smooth lower boundary, A horizon.

Zone 3: 15-63 cmbs, pale brown (10YR6/3) friable fine sandy loam, common rootlets, few roots, gradual smooth lower boundary, E1 horizon.

Zone 4: 63-90 cmbs, very pale brown (10YR7/3) friable to slightly firm fine sandy loam, few roots and rootlets, clear smooth lower boundary, E2 horizon.

Zone 5: 90-95 cmbs, light gray (10YR7/2) slightly firm silty sandy loam, chert pebbles sub-rounded to rounded at bottom of zone, clear wavy lower boundary, B horizon.

Zone 6: 95+ cmbs, light grayish brown (10YR6/2) medium sandy clay loam, medium subangular blocky structure, common faint to distinct medium strong brown (7.5YR5/6) mottles, lower boundary not observed, 2Bt horizon.

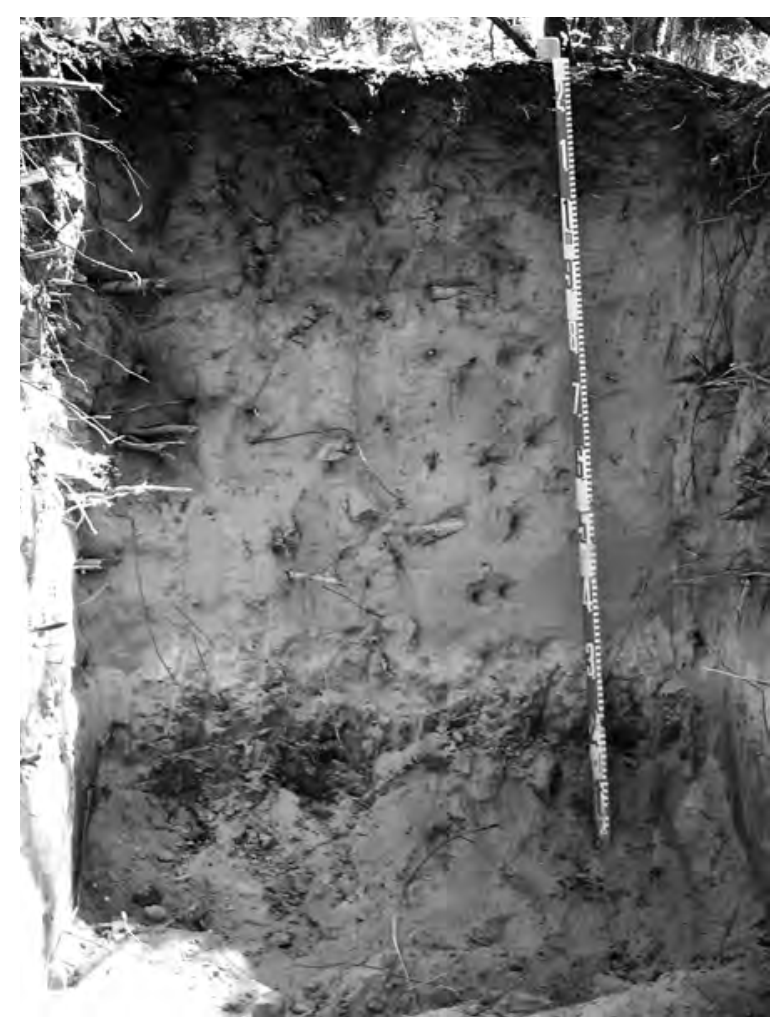

Figure 3-16. Profile 17 in BHT 5 at 41BP111. 
Table 3-2. Approximate depths of artifact recovery from backhoe trenches at 41BP111. When no depth could be recorded, artifact depth is listed as "unknown.”

\begin{tabular}{|c|c|c|c|c|c|c|}
\hline Trench & $\begin{array}{c}\text { Bottom } \\
\text { Elevation } \\
\text { (cmbs) }\end{array}$ & $\begin{array}{c}\text { Clay } \\
\text { Reached? }\end{array}$ & $\begin{array}{c}\text { Debitage } \\
\text { (cmbs) }\end{array}$ & $\begin{array}{c}\text { Charcoal } \\
\text { (cmbs) }\end{array}$ & $\begin{array}{c}\text { FCR } \\
\text { (cmbs) }\end{array}$ & $\begin{array}{c}\text { Others } \\
\text { (cmbs) }\end{array}$ \\
\hline BHT 1 & 150 & yes & unknown & - & 50 & flake core at 25-30 \\
\hline BHT 2 & 170 & yes & - & - & unknown & - \\
\hline BHT 3 & 190 & yes & - & - & 45 & - \\
\hline BHT 4 & 170 & yes & - & - & - & - \\
\hline BHT 5 & 95 & yes & - & - & - & - \\
\hline
\end{tabular}

Artifacts observed in the backhoe trenches were considerably uneven. Backhoe Trench 1 yielded moderate amounts of cultural debris, while Trenches 4 and 5 contained no observed artifact material (Table 3-2). A large flaked chert cobble (Figure 3-17) was recovered from the south end of Trench 1, located close to the hearth visible on the surface. This chert core was split by hard, perhaps bi-polar, percussion and shows the removal of three or four medium to large flakes. The material is light gray, fine grained, with small to very small circular inclusions. Although the original size of the cobble cannot be known, the core is larger than most other cobbles observed in Uvalde Gravel outcrops across the Camp Swift area. It is therefore possible that the core was collected at some distant location where heavier gravels occur, perhaps along one of the primary tributary systems of the Colorado River, and brought to this site. The core's proximity to the hearth shown in Figure 3-10 and their comparable elevations suggest that they are part of the same site component representing lithic reduction activities that took place close to the camp or cooking fire.

This site includes a wide distribution of artifacts across a variable landform. Material culture concentrations were documented in close association with an intact feature.

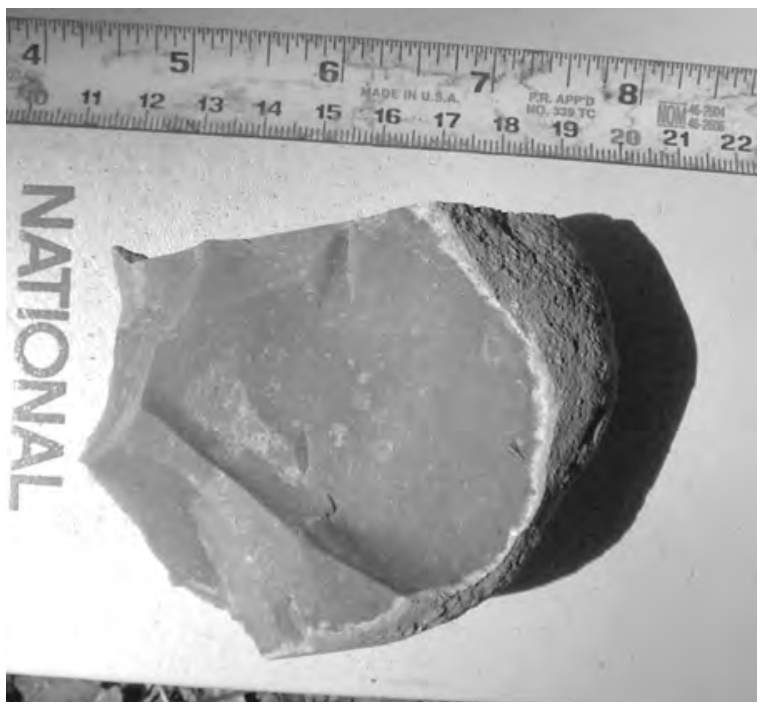

Figure 3-17. Large flake core recovered from BHT 1 at approximately 20-30 cmbs. It is part of the same component that includes the hearth shown in Figure 3-10.

Moreover, the distribution of artifacts around this feature indicates that activity areas can be identified that provide supplementary information about the site. These results confirm the original assessment of the site as an open campsite (see Table 1-1) with lithic reduction activities. Clearly, this site holds some, but unknown, potential for containing additional, comparable components. Therefore, it is considered potentially eligible for listing to the NRHP and additional work is recommended. 


\section{BP113}

Originally recorded in 1979 (Skelton and Freeman 1979) and revisited by archaeologists from The University of Texas at San Antonio (Robinson 2001), this site was described by Nickels and Lehman (2004b:37-38) as an open prehistoric campsite with burned rock and an associated lithic scatter. The site is located in a now-open field along a sideslope overlooking an intermittent drainage of McLaughlin Creek. Tall grasses and mixed weeds dominate ground cover in the field, and oak and juniper make up the surrounding wooded areas. Soils that cover the landform fall into the Patilo complex.

Skelton and Freeman (1979) excavated a $1 \times 2-m$ unit in their original work and recovered a number of debitage pieces refl ecting stone reduction activities. A cluster of firecracked rock was also observed on the creek's edge, though no assessment was made about whether this deposit was natural or cultural. Robinson (2001:131) excavated a single shovel test, recovering four flakes from between 20-80 cmbs. During the CAS revisit and reassessment of the site, 26 shovel tests were excavated, recovering a fairly moderate amount of cultural debris that included fire-cracked rocks $(n=45)$, abundant debitage, utilized flakes, and a mussel shell (Figure 3-18). A probable hearth feature was also exposed in Shovel Test 5 at 50-60 cmbs.
In the current testing effort, five backhoe trenches were excavated at 41BP113 near CAS STs 4, 5, 9, 13, 15, and 17. Backhoe trench profiles were described for each and are provided below followed by a photograph of the profile described (Figures 3-19 to 3-23). The documentation of sediments in the profiles shows that a $2 \mathrm{Bt}$ horizon was observed at 32, 115, and $131 \mathrm{cmbs}$ in BHTs 1, 2, and 4. In the upper portion of the pedon was a A-B or A-E-B horizon sequence with no stratigraphic breaks.

\section{Description of sediments in BHT 1 (Profile 1) at $41 B P 113$}

Zone 1: 0-1 cmbs, very dark gray (10YR3/1) very friable sand, few rootlets and roots mixed with decomposing leaf litter and small twigs, very abrupt wavy lower boundary, O horizon.
FIGURE 3-18. REDACTED
Figure 3-18. Map of 41BP113 showing locations of backhoe trenches and 2002-2003 shovel tests (adapted from Nickels and Lehman 2004b: Figure 4-18). 
Zone 2: 1-11 cmbs, very pale brown (10YR7/4) slightly firm fine sandy loam, common rootlets and some organic particulate mixing from above, abrupt smooth lower boundary, A horizon.

Zone 3: 11-21 cmbs, very pale brown (10YR7.5/4) friable fine sandy loam, rare small (5 mm diameter) ironstone nodules, few roots and rootlets, abrupt smooth lower boundary, E horizon.

Zone 4: 21-32 cmbs, light brownish gray (10YR6/2.5) friable sandy loam, common roots and rootlets; Feature 1 at bottom of zone, very abrupt wavy lower boundary, B horizon.

Zone 5: 32-50+ cmbs, reddish yellow (7.5YR6/6) very firm sandy clay loam medium strong subangular blocky structure, few roots and rootlets; clay films on ped faces, 20 percent yellowish-red (5YR5/6) mottles, lower boundary not observed, 2Bt horizon.

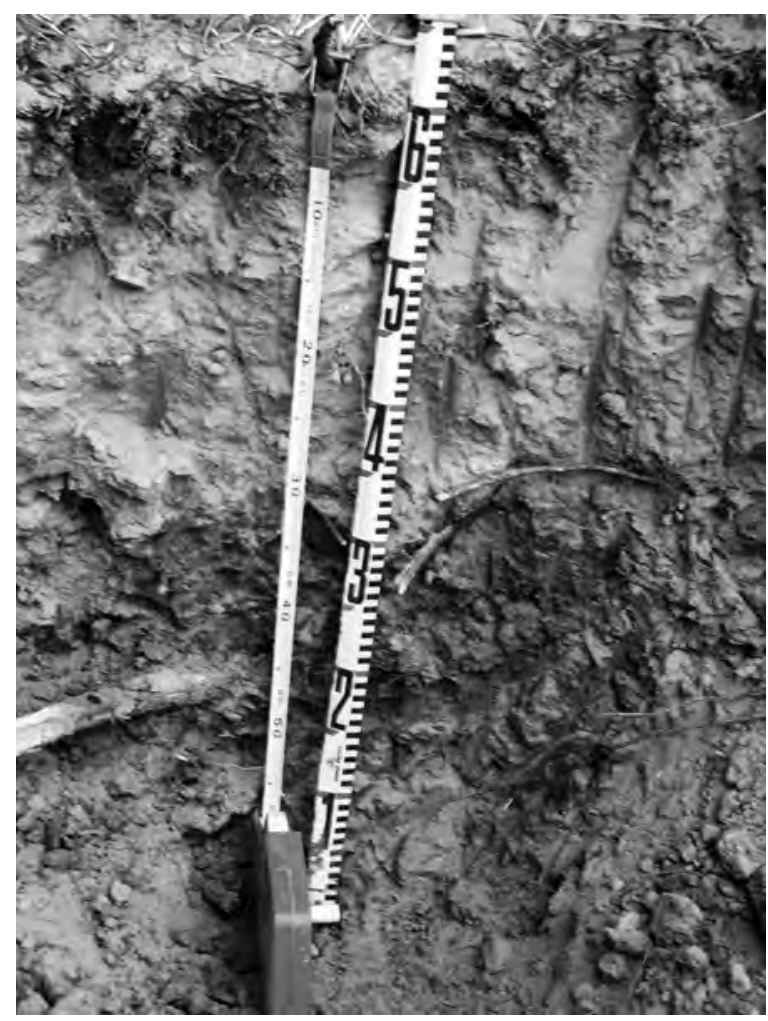

Figure 3-19. Profile 1 in BHT 1 at 41BP113.

\section{Description of sediments in BHT 2 (Profile 2) at $41 B P 113$}

Zone 1: 0-9 cmbs, grayish brown (10YR5/2.5) friable sandy loam, thin leaf litter on surface with grass, dense rootlets, few roots, abrupt smooth lower boundary, A horizon.

Zone 2: 9-45 cmbs, pale brown (10YR6/3) very friable to loose fine sandy loam, common rootlets, few roots and ironstone pebbles $(\leq 5$ $\mathrm{mm}$ diameter), abrupt smooth lower boundary, B1 horizon.

Zone 3: 45-65 cmbs, pale brown (10YR6/3) slightly firm fine sandy loam, very weak medium subangular blocky structure, few $(\leq 8$ $\mathrm{mm}$ diameter) ironstone and quartzite pebbles, clear smooth lower boundary, B2 horizon.

Zone 4: 65-115 cmbs, very pale brown (10YR7/3) friable to slightly firm fine sandy loam, firmer down profile (almost crunchy),

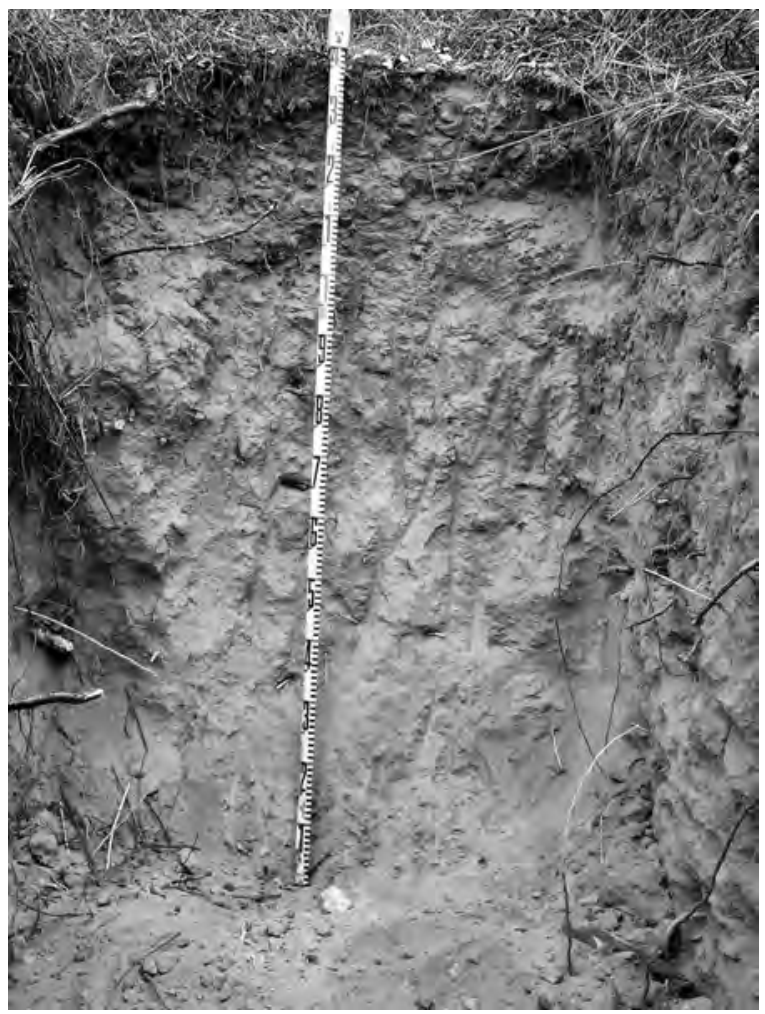

Figure 3-20. Profile 2 in BHT 2 at 41BP113. 
ironstone concretions and pebbles up to $18 \mathrm{~mm}$; ironstone concretions increase down profile; few roots and rootlets; Feature 2 at $85-90$ cmbs, clear wavy lower boundary, B3 horizon.

Zone 5: 115-130+ cmbs, pale brown (10YR6/3) firm, medium sandy clay loam, strong brown (7.5YR5/6) medium mottles that increase in frequency down profile, lower boundary not observed, 2Bt horizon.

\section{Description of sediments in BHT 3 (Profile 3) at $41 B P 113$}

Zone 1: 0-5 cmbs, grayish brown (10YR5/2) loose fine sandy loam, thick grass cover, dense rootlets abrupt wavy lower boundary, A horizon.

Zone 2: 5-90+ cmbs, pale brown (10YR6/3) slightly firm fine sandy loam, massive structure, Feature 3 at $75-80$ cmbs in west profile with possible Pedernales projectile point base; burrows at 23, 36, 41 , and 42 cmbs $(\leq 8 \mathrm{~cm}$ diameter), lower boundary not observed, B horizon.

\section{Description of sediments in BHT 4 (Profile 4) at $41 B P 113$}

Zone 1: 0-7 cmbs, pale brown (10YR6/3), leaf litter and twigs grading down to dense rootlets, clear wavy lower boundary, Ap1 horizon.

Zone 2: 7-25 cmbs, pale brown (10YR6/3) friable to loose fine sandy loam, common rootlets, abrupt wavy lower boundary, Ap2 horizon.

Zone 3: 25-91 cmbs, pale brown (10YR6/3) friable to slightly firm sandy loam, massive structure

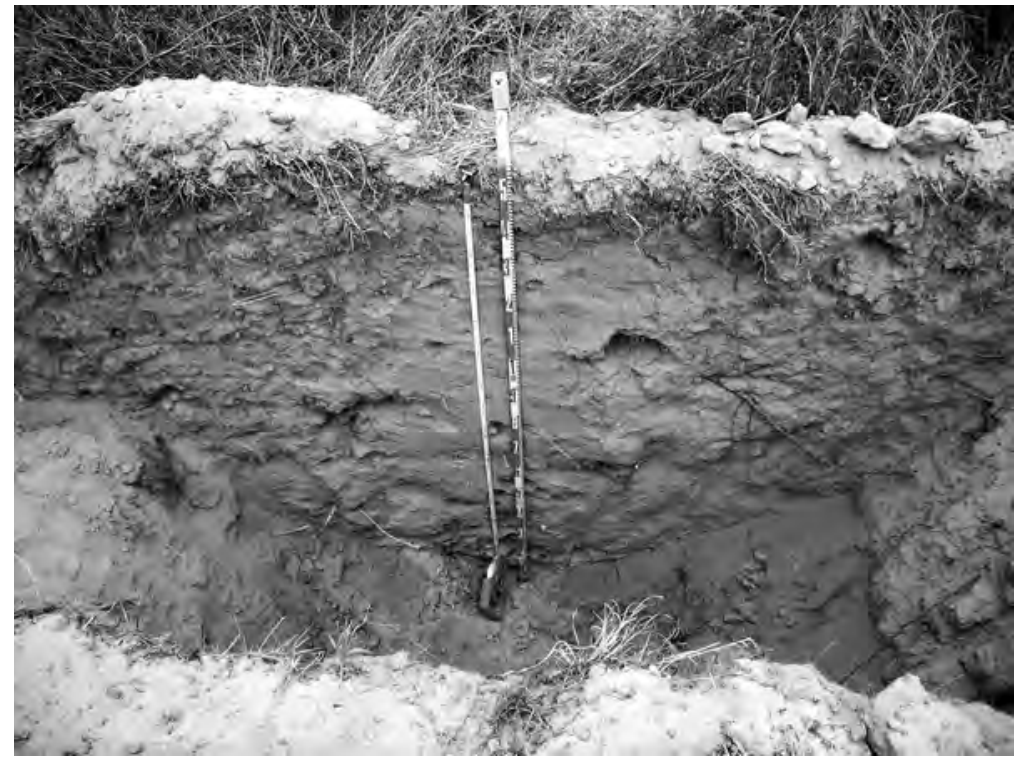

Figure 3-22. Profile 4 in BHT 4 at 41BP113. 
Zone 4: 91-131 cmbs, very pale brown (10YR7/3) firm sandy loam, few roots, becomes firmer down profile; burned rocks at 108 and 123 cmbs, yellowish brown (7.5YR6/6) mottles surrounding ironstone concretions $(<5$ percent) in lower $15 \mathrm{~cm}$, clear smooth lower boundary, B2 horizon.

Zone 5: 131-145+ cmbs, very pale brown (10YR8/2) medium sandy clay loam, brownish to yellow (7.5YR4/3 to 10YR6/6) medium faint to distinct mottles, lower boundary not observed, 2Bt horizon.

\section{Description of sediments in BHT 5 (Profile 5) at 41BP113}

Zone 1: 0-20 cmbs, very pale brown (10YR7/3) loose fine sand, abundant rootlets, few roots, clear smooth to wavy lower boundary, Ap horizon.

Zone 2: 20-62 cmbs, very pale brown (10YR7/4) friable fine sand, common rootlets, few roots, clear smooth lower boundary, B1 horizon.

Zone 3: 62-95 cmbs, pale brown (10YR6/3) friable to slightly firm fine sandy loam, few rootlets, occasional roots; few ironstone pebbles ( $<1$ percent), fire-cracked rock at 80 and $82 \mathrm{cmbs}$, clear smooth lower boundary, B2 horizon.

Zone 4: 95-122 cmbs, light yellowish brown (10YR6.5/4) friable to slight firm sandy loam, few rootlets, rare roots, $<1$ percent ironstone pebbles up to $11 \mathrm{~mm}$, strong brown (7.5YR5/8) fine to medium, faint to distinct firm mottles, clear smooth lower boundary, B3 horizon.

Zone 5: $122-140+$ cmbs, very pale brown (10YR7/4) medium sandy loam, lower boundary not observed, Bt horizon.

Cultural materials were observed in BHTs 1 through 4 . BHT 5 might have been placed in a

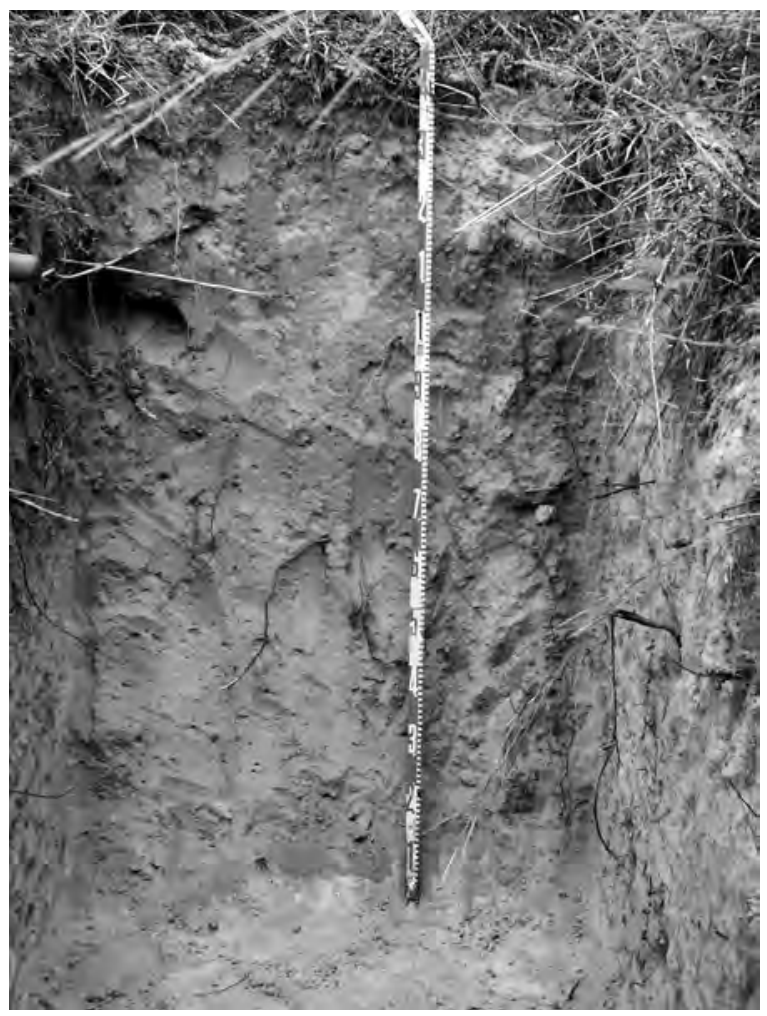

Figure 3-23. Profile 5 in BHT 5 at 41BP113.

sterile part of the site, or else cultural debris was simply not observed in the monitoring process (Table 3-3). Three burned rock features were recorded. Feature 1, in BHT 1 at approximately 35 cmbs, was a loose cluster of fire-cracked rock. This cluster was moderately disturbed by the backhoe bucket, though was still dense in its concentration (due to poor lighting conditions, none of the field photographs taken of Feature 1 were salvageable). Feature 2 was located in BHT 2 approximately 85 cmbs (Figure 3-24). This feature was a large cluster of mostly quartzite rocks, many of which were fire-cracked. Approximately 80 percent of the rocks in this cluster were removed in a single backhoe bucket (Figure 3-25), but enough remained in place in the bottom of the trench to document the feature. Feature 3, located in BHT 3, was exposed in the profile of the trench at approximately 75-80 cmbs (Figures 3-26 and 3-27). This feature was much less extensive than 
Table 3-3. Approximate depths of artifact recovery from backhoe trenches at 41BP113. When no depth could be recorded, artifact depth is listed as "unknown."

\begin{tabular}{|c|c|c|c|c|c|c|}
\hline Trench & $\begin{array}{c}\text { Bottom } \\
\text { Elevation } \\
\text { (cmbs) }\end{array}$ & $\begin{array}{c}\text { Clay } \\
\text { Reached? }\end{array}$ & $\begin{array}{c}\text { Debitage } \\
\text { (cmbs) }\end{array}$ & $\begin{array}{c}\text { Charcoal } \\
\text { (cmbs) }\end{array}$ & $\begin{array}{c}\text { FCR } \\
\text { (cmbs) }\end{array}$ & $\begin{array}{c}\text { Others } \\
\text { (cmbs) }\end{array}$ \\
\hline BHT 1 & 50 & yes & - & - & - & Feature 1 at 35 \\
\hline BHT 2 & 130 & yes & - & - & - & Feature 2 at 90 \\
\hline BHT 3 & 90 & no & $\begin{array}{c}80-90, \\
\text { unknown }\end{array}$ & - & $80-90$ & $\begin{array}{c}\text { Feature 3 at 85, } \\
\text { dart point base at unknown }\end{array}$ \\
\hline BHT 4 & 145 & yes & - & - & $80-90$ & $\begin{array}{c}\text { flaked chert pebble at } \\
\text { unknown }\end{array}$ \\
\hline BHT 5 & 140 & yes & - & - & 80 & - \\
\hline
\end{tabular}

Feature 2, measuring approximately one meter in length along the west wall of the trench. The quartzite rocks were found lying at a consistent elevation; no basin shape was observed in the feature's cross section.

In addition to Feature 3, a large interior flake (Figure 3-28) and the base of a dart point (Figure 3-29) were recovered from BHT 3. The flake was struck from a large biface; multiple flake scars on its dorsal side originate from many directions. The material is very fine

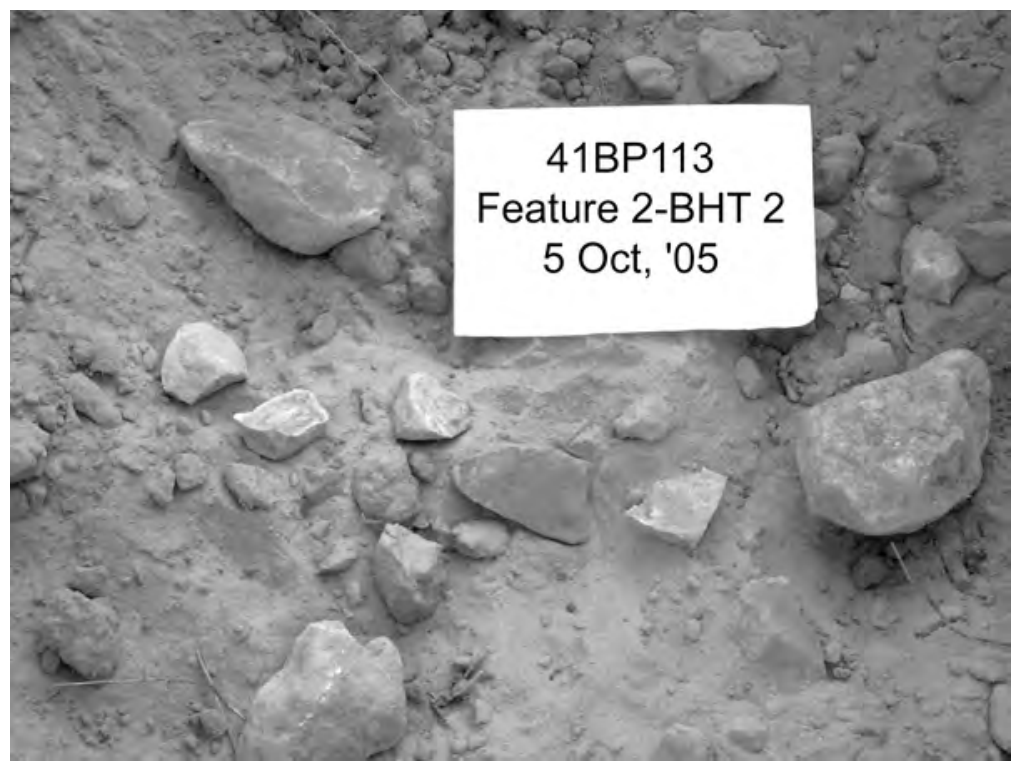

Figure 3-24. Remains of Feature 2 in BHT 2. grained in texture and is opaque to translucent very dark brown in color. This kind of chert is frequently called "root beer brown," and is common along the Balcones Escarpment range in the area between San Marcos and San Antonio and extending to the south and west. It is also found in downstream gravel deposits originating from these areas. The exact provenience of the dart point base is not known, but it was spotted in the loose sand at the same depth as Feature 3, approximately 85 cmbs. Stylistically, it resembles an atypical Pedernales point type with its squared stem, mild shoulders, and slightly concave base. The point was crafted from light gray chert strongly resembling the Georgetown variety of Edward's chert. Even while it does not easily fit any type category, it is almost certainly Late Archaic in age. Backhoe Trench 3 was not excavated all the way to the underlying red clay substratum because of the density and nature of artifact materials that were observed.

Cultural debris including chert debitage was also noted 


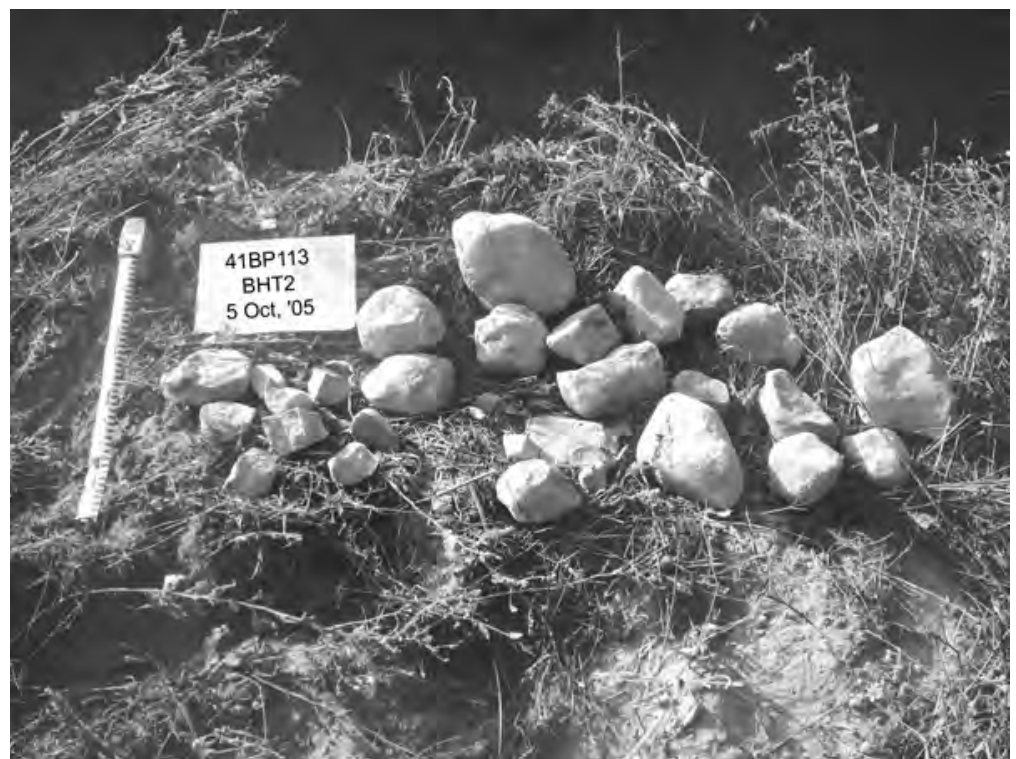

Figure 3-25. Fire-cracked and other rocks removed from a single backhoe bucket that disturbed Feature 2, located at approximately 85 cmbs in BHT 2.

in BHT 4 at the same depth ranges as described for BHT 3. These remains also included a number of pieces of fire-cracked rock, though not in any concentration or cluster that would warrant designation as a feature. A flaked chert pebble was observed from this elevation at the south end of the trench. As with BHT 3, the south end of this trench was left at approximately 90 cmbs; the north end was excavated to the underlying reddish clay substratum. Given the comparable depths and natures of the deposits from BHTs 3 and 4, CAS archaeologists believe that a concentration of prehistoric material characterizes this part of site 41BP113 and may extend northwestward to BHT 2. This concentration has multiple intact features, potentially more than were exposed, as well as temporally diagnostic artifacts in addition to chipping debris and scattered remains of other activities involving, or producing, fire-cracked rocks.

Based on the kinds of artifacts observed at this site, the previous assessment as an open campsite (see Table 1-1) is supported. The dart point fragment indicates that at least some of the material from the site can be dated to the Late Archaic. The presence of intact features and discretely patterned deposits warrant a recommendation of potential eligibility for listing to the NRHP. Additional work is recommended to explore further the nature and extent of archaeological materials at this site.

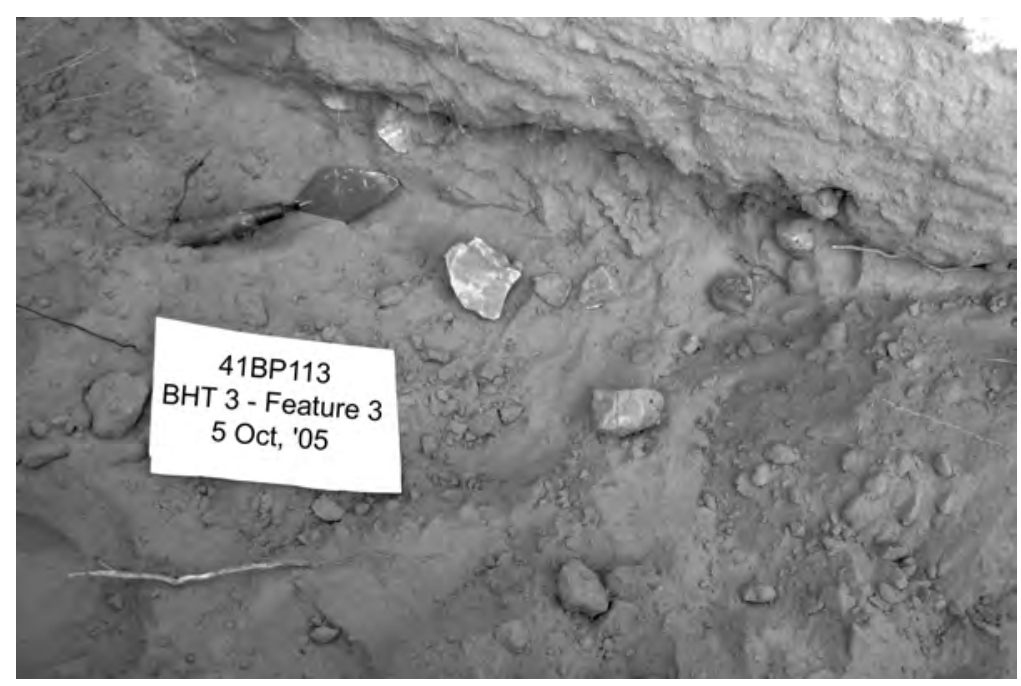

Figure 3-26. Feature 3 in BHT 3 at approximately 85 cmbs, looking southwest. 


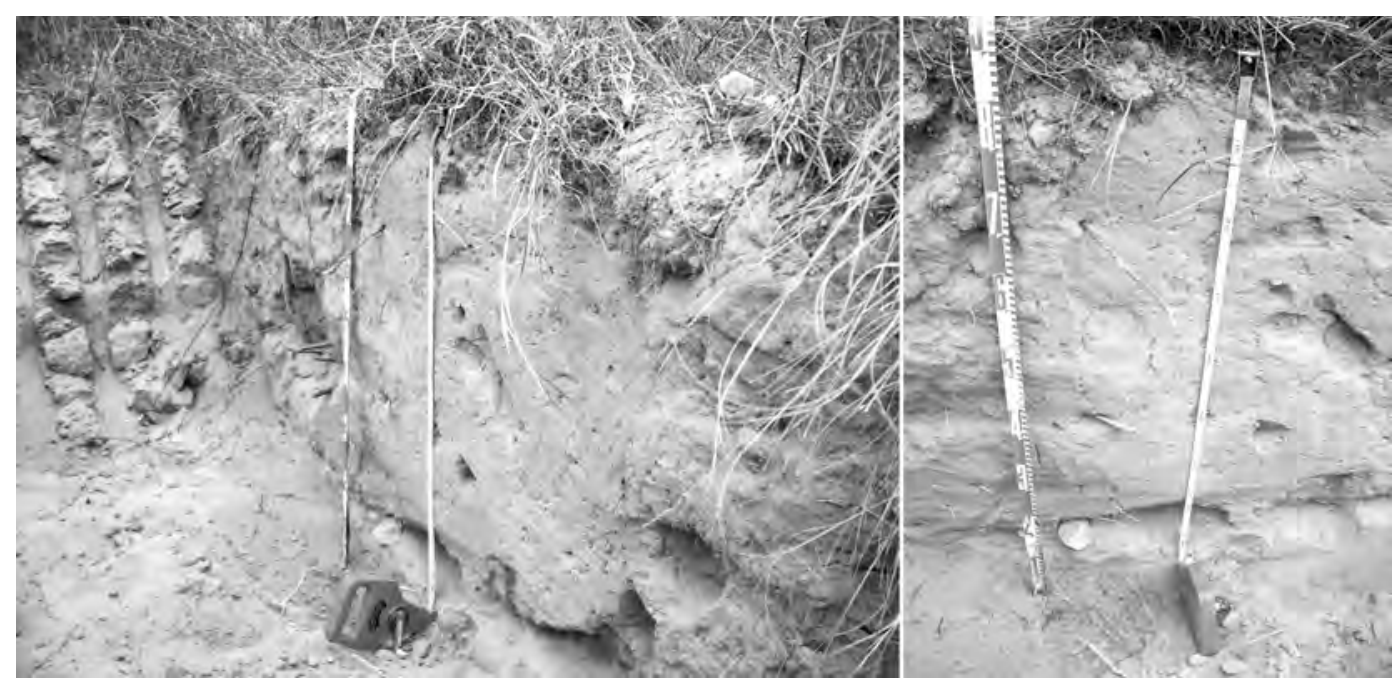

Figure 3-27. Feature 3 in west wall of BHT 3 (at bottom directly above tape spool), looking southwest (left) and west (right) as trench profiles are being described.

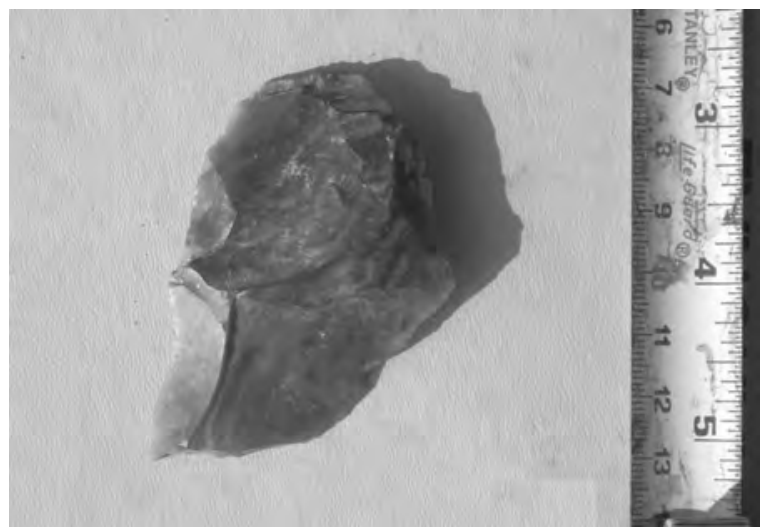

Figure 3-28. Large interior bifacial thinning flake of "root beer brown" chert from BHT 3.

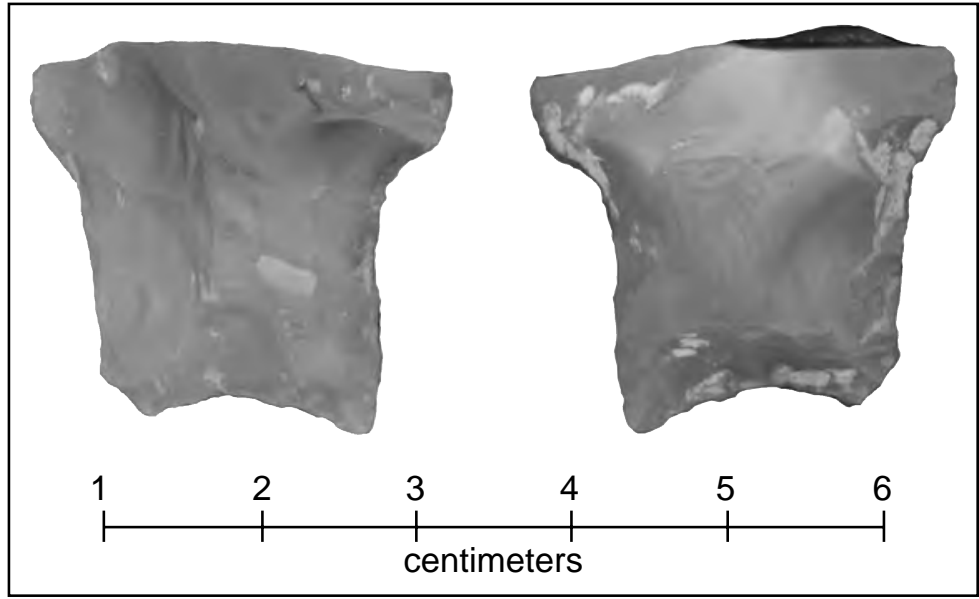

Figure 3-29. Late Archaic dart point base made of Edwards chert, found in BHT 3. 


\section{BP118}

This site was originally recorded by Skelton and Freeman (1979), who found it in an open sideslope next to an intermittent drainage of McLaughlin Creek. The site is located in a small clearing quite close to 41BP113. Moderately tall mixed grasses and weeds provide ground cover, with nearby wooded areas comprised of juniper, oak, and pine following along the drainage. Soils across the site are classified as the Crockett soils.

Skelton and Freeman described a biface, a quartzite hammerstone, and two core fragments eroding out of the edge of a nearby slope. A 1x2-m unit hand excavated by those researchers produced abundant debitage including 80 flakes, three utilized flakes, over 100 pieces of fire-cracked rock, and a Late Archaic Marshall-like dart point. Skelton and Freeman (1979) also recorded two firecracked rock hearth remnants between 28 and 35 cmbs. CAS archaeologists revisited and reassessed the site in 2002-2003 (Nickels and Lehman 2004b:4042). They excavated eight shovel tests and collected 12 pieces of fire-cracked rock, 11 flakes, a core, and a biface, and described the site as an open prehistoric campsite with burned rock and associated lithic scatter. CAS shovel tests ranged between only 20 to 110 cmbs, reflecting the high degree of variability in subsurface deposits. Cultural remains were recovered from 2002-2003 CAS STs 5 and 6 from as deep as $100 \mathrm{~cm}$.
Based on the frequency and nature of artifacts recovered in the 2002-2003 CAS shovel tests, two backhoe trenches were excavated in 2005 near CAS STs 5 and 6 (Figure 3-30). Backhoe trench profiles were described for each and are provided below followed by a photograph of the profile described (Figures 3-31 and 3-32). The two backhoe trenches exposed sediments with thin A-B soil horizons above a shallow 2Bt horizon encountered at 77 and 84 cmbs in BHTs 1 and 2, respectively. No stratigraphic breaks were observed in the overlying arenaceous A-B horizons.

\section{Description of sediments in BHT 1 (Profile 6) at $41 B P 118$}

Zone 1: 0-25 cmbs, pale brown (10YR6/3) friable fine sandy loam, grass cover on surface,

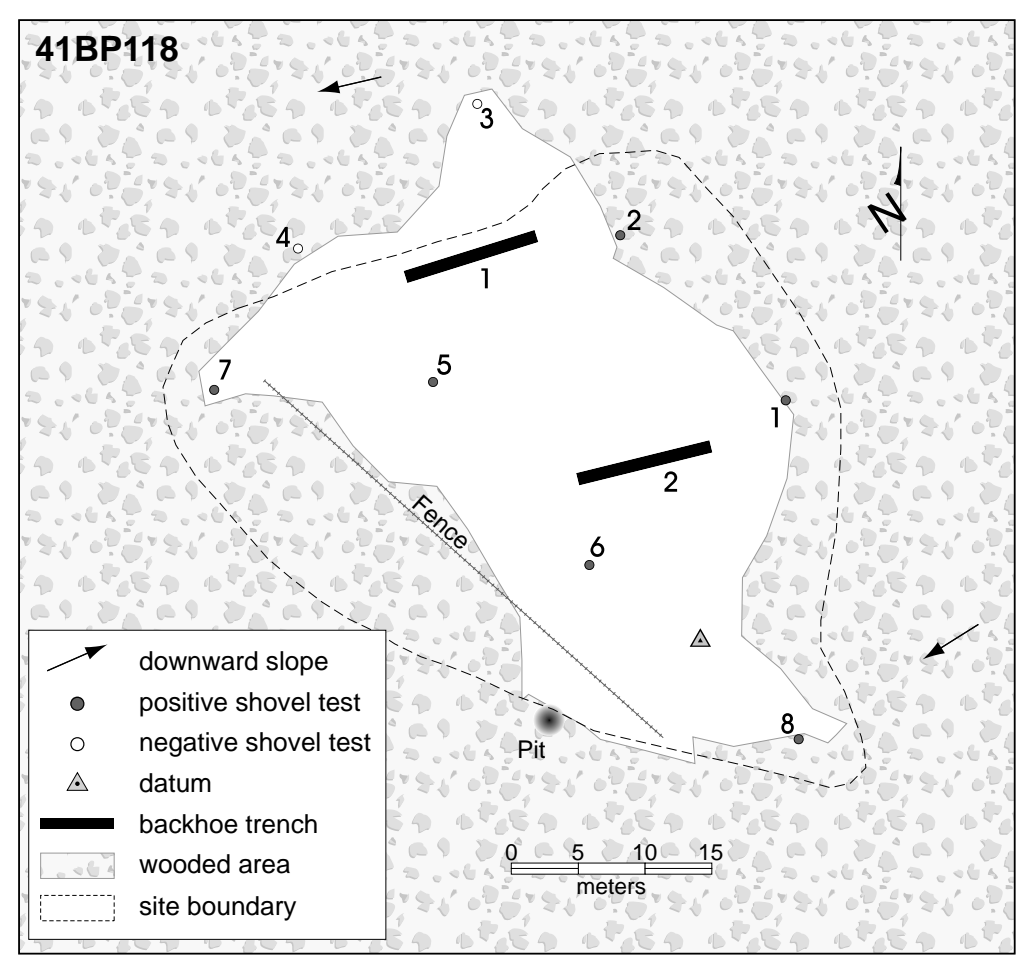

Figure 3-30. Map of 41BP118 showing locations of backhoe trenches and 2002-2003 shovel tests (adapted from Nickels and Lehman 2004b: Figure 4-20). 


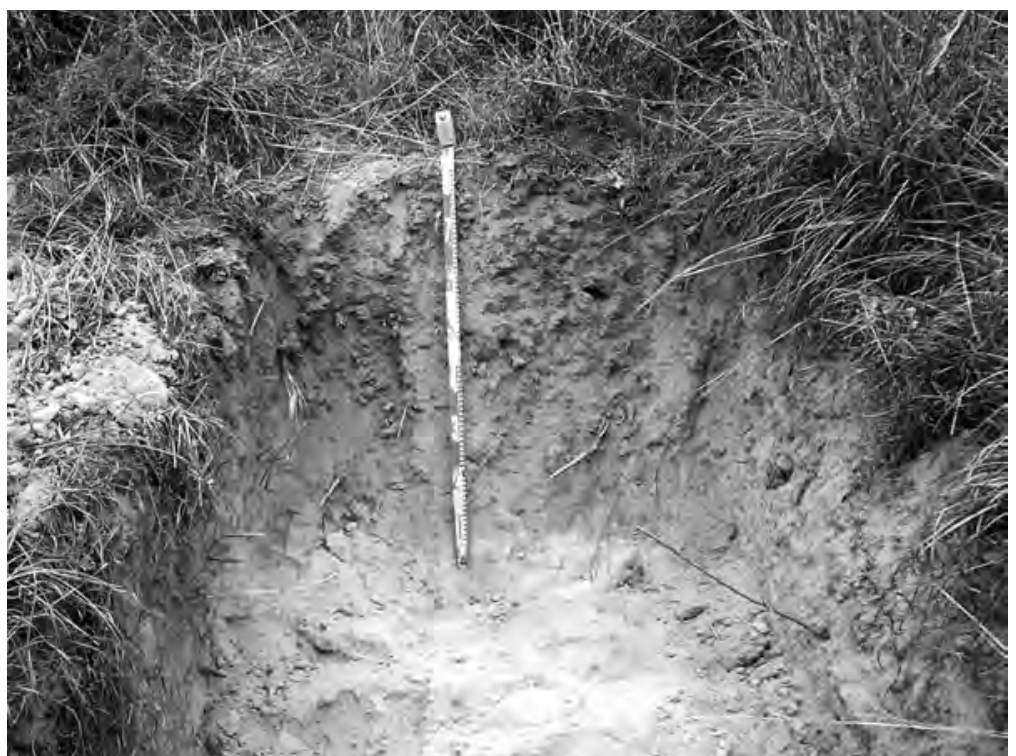

Figure 3-31. Profile 6 in BHT 1 at 41BP118.

common rootlets, small insect burrows throughout zone, clear smooth lower boundary, A horizon.

Zone 2: 25-56 cmbs, light yellowish brown (10YR6/4) friable fine sandy loam, few rootlets and insect burrows, less than Zone 1; rare ironstone nodules up to $4 \mathrm{~cm}$, small rodent burrow at $29 \mathrm{cmbs}, 5 \mathrm{~cm}$ in diameter, clear smooth lower boundary, B1 horizon.

Zone 3: 56-77 cmbs, pale brown (10YR6/3) slightly firm fine sandy loam, few rootlets and roots; small, up to $5 \mathrm{~mm}$, ironstone nodules and pebbles, more firm down profile, clear smooth lower boundary, B2 horizon.

Zone 4: 77+ cmbs, light gray (10YR7/2) firm medium clayey sand, common brownish yellow (10YR7/2) faint to distinct medium mottles, lower boundary not observed, 2Bt horizon.

\section{Description of sediments in BHT 2 (Profile 7) at $41 B P 118$}

Zone 1: 0-13 cmbs, very pale brown (10YR7/4) loose to friable fine sandy loam, common rootlets, clear smooth lower boundary, A horizon.

Zone 2: 13-43 cmbs, pale brown (10YR6/3) friable fine sandy loam, common rootlets, few ironstone concretions and pebbles, small rodent burrow at 33 cmbs, abrupt smooth lower boundary, B horizon.

Zone 3: 43-63 cmbs, grayish brown (10YR5/2) friable fine sandy loam, common rootlets, clear smooth, Ab horizon.

Zone 4: 63-84 cmbs, pale brown (10YR6/3) friable fine sandy loam, common rootlets; few small ironstone concretions and pebbles, very abrupt wavy lower boundary, B horizon.

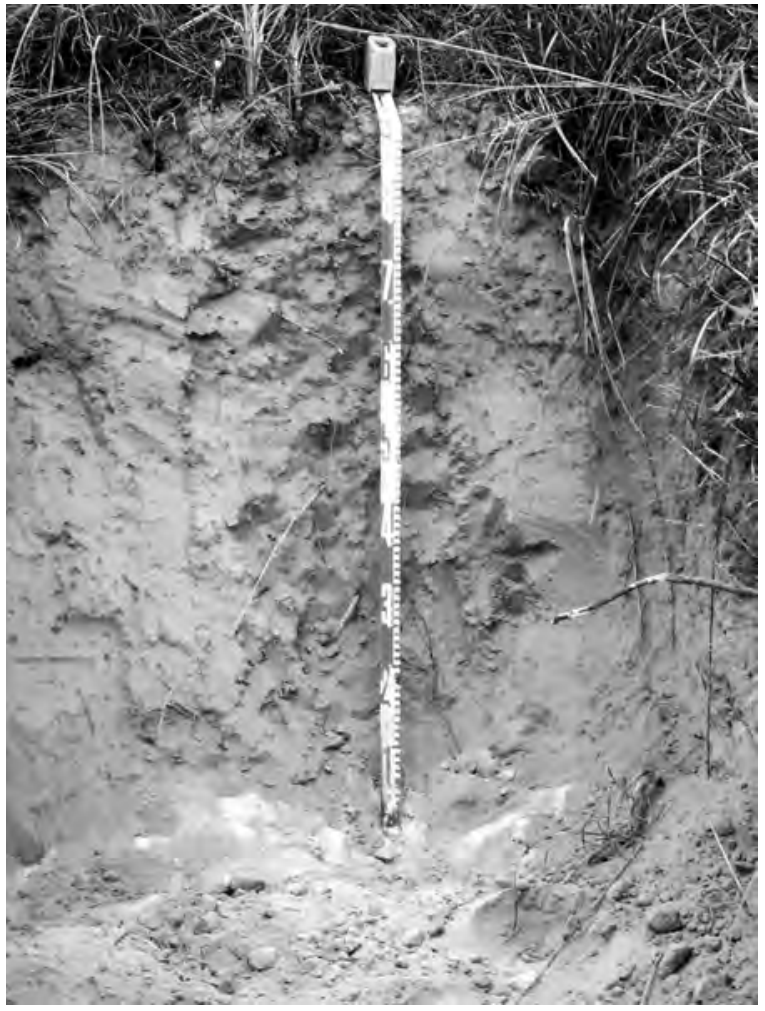

Figure 3-32. Profile 7 in BHT 2 at 41BP118. 
Zone 5: 84+ cmbs, very pale brown (10YR 7/4) firm medium clayey sand, common reddish yellow (7.5YR7/6) faint medium mottles, lower boundary not observed, 2Bt horizon.

No definite cultural materials were observed or recovered from either of the two backhoe trenches excavated at this site (Table 3-4). A heavy layer of chert, quartzite, and ironstone gravels was exposed directly over the clayey sand 2Bt horizon (Figure 3-33); some of the rocks found in this layer exhibited sharp angular patterns of fracture as if from exposure to extreme heat. However, considering the geomorphic context within which these were found, these cannot be confidently identified as fire-cracked rock. Many also exhibit some rounding and weathering of edges consistent with water-borne transport and deposition.

The age of this site is currently unknown. On the basis of artifacts observed during the current phase of research, its original assessment as an open campsite is confirmed. However, because no features were observed, it is not considered potentially eligible for listing to the NRHP and no further work is recommended.

Table 3-4. Approximate depths of artifact recovery from backhoe trenches at 41BP118. When no depth could be recorded, artifact depth is listed as "unknown."

\begin{tabular}{|c|c|c|c|c|c|c|}
\hline Trench & $\begin{array}{c}\text { Bottom } \\
\text { Elevation } \\
\text { (cmbs) }\end{array}$ & $\begin{array}{c}\text { Clay } \\
\text { Reached? }\end{array}$ & $\begin{array}{c}\text { Debitage } \\
\text { (cmbs) }\end{array}$ & $\begin{array}{c}\text { Charcoal } \\
\text { (cmbs) }\end{array}$ & $\begin{array}{c}\text { FCR } \\
\text { (cmbs) }\end{array}$ & $\begin{array}{c}\text { Others } \\
\text { (cmbs) }\end{array}$ \\
\hline BHT 1 & 77 & yes & - & - & - & - \\
\hline BHT 2 & 84 & yes & - & - & - & - \\
\hline
\end{tabular}
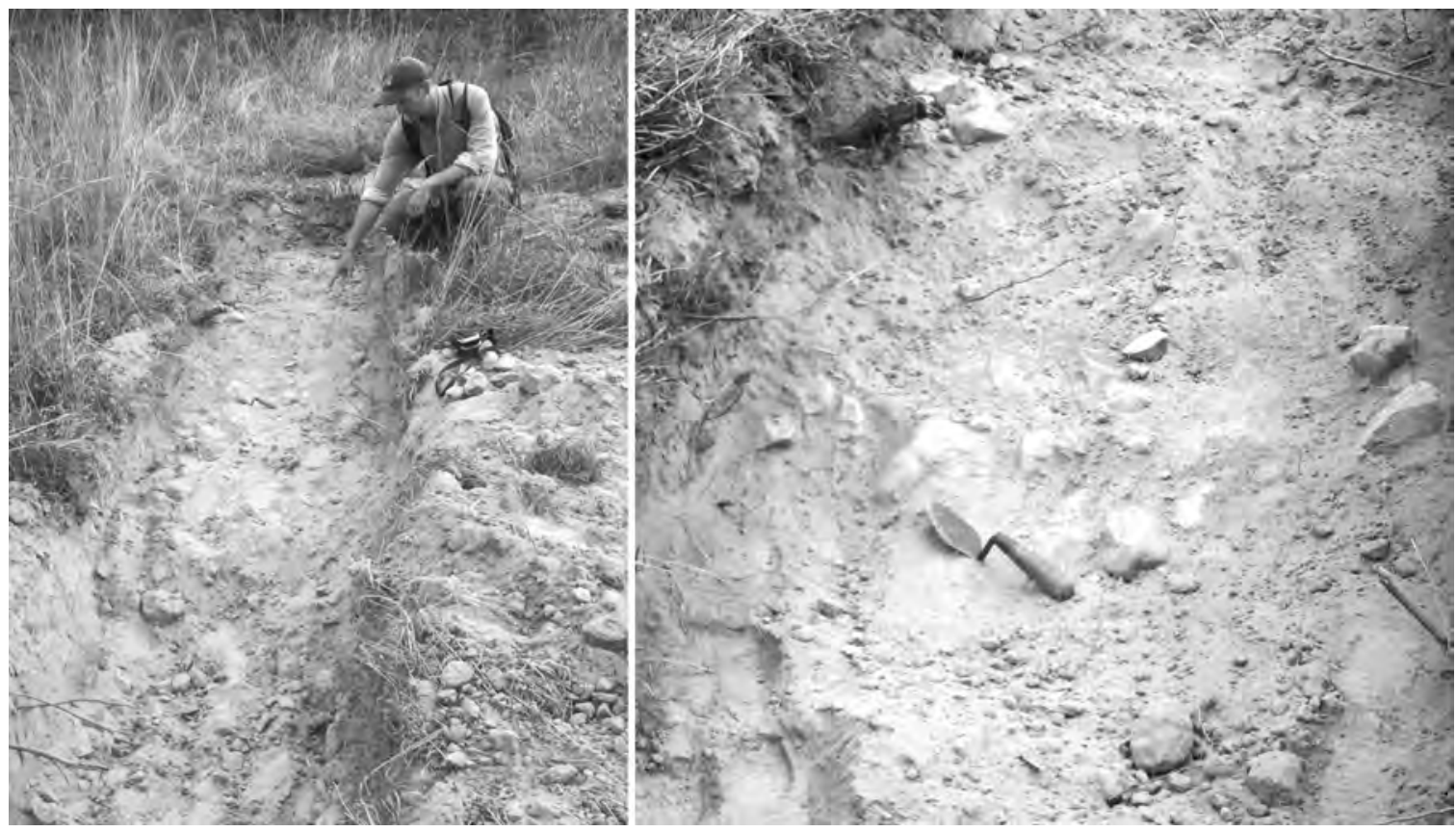

Figure 3-33. CAS archaeologist David Payton (left, looking northeast) indicating the heavy natural gravels (close-up at right) underlying sandy sediments and over the red clay substratum in BHT 1 at 41BP118. 


\section{BP121}

This site is described as a prehistoric open campsite with associated burned rock and lithic scatter. It was originally recorded by Skelton and Freeman (1979), who identified cultural remains on a sideslope in a generally wooded area supporting stands of juniper, oak, and mesquite. Soils covering the site area are classified as Demona loamy fine sand. The central area of the site is open though covered with heavy grasses and mixed weeds.

In their initial survey, Skelton and Freeman excavated a $1 \mathrm{x} 2-\mathrm{m}$ test unit, controlled in $25-\mathrm{cm}$ arbitrary levels, from which they recovered 383 unmodified flakes, five utilized flakes, 13 socalled cores, a hammerstone, over 370 pieces of fire-cracked rock, and a Late Archaic Montelllike dart point (Nickels and Lehman 2004b:43). A hearth feature consisting of a cluster of burned rocks was also reported 50-75 cmbs. The site was revisited by TXARNG archaeologists (Robinson 2001), who excavated three shovel tests and reported two flakes and two pieces of burned rock. When CAS personnel revisited the site in 2002-2003, they noted some discrepancy in the exact locations given for the site by the two teams of previous researchers. Accordingly, shovel tests were conducted at both locales, identified as Areas A and B, which are separated from each other by New Road (Figure 3-34). Based on the results of their shovel tests, Nickels and Lehman (2004b:45) believe
Area B to be the site described by Skelton and Freeman (1979).

A total of 30 additional shovel tests were excavated across both site areas by CAS archaeologists in 2002-2003. The deepest of these reached $110 \mathrm{cmbs}$, while others ranged from $20-30 \mathrm{cmbs}$ to $100 \mathrm{cmbs}$. The underlying clay substratum was reached in all of the shallow units but not all of the ones that extended below a meter in depth. Cultural materials recovered by CAS archaeologists included 22 interior and exterior flakes, three utilized flakes, and fire-cracked rock. Pieces of clear and brown glass were recovered from ST 15. Initial shovel tests were placed by CAS in 2002, but when those personnel returned to the site in 2003 they observed several artifacts lying on the surface of New Road, including a scatter of flakes and a bifacial core. Scattered
Figure 3-34. Map of 41BP121 showing locations of backhoe trenches and 2002-2003 shovel tests (adapted from Nickels and Lehman 2004b: Figure 4-22). 


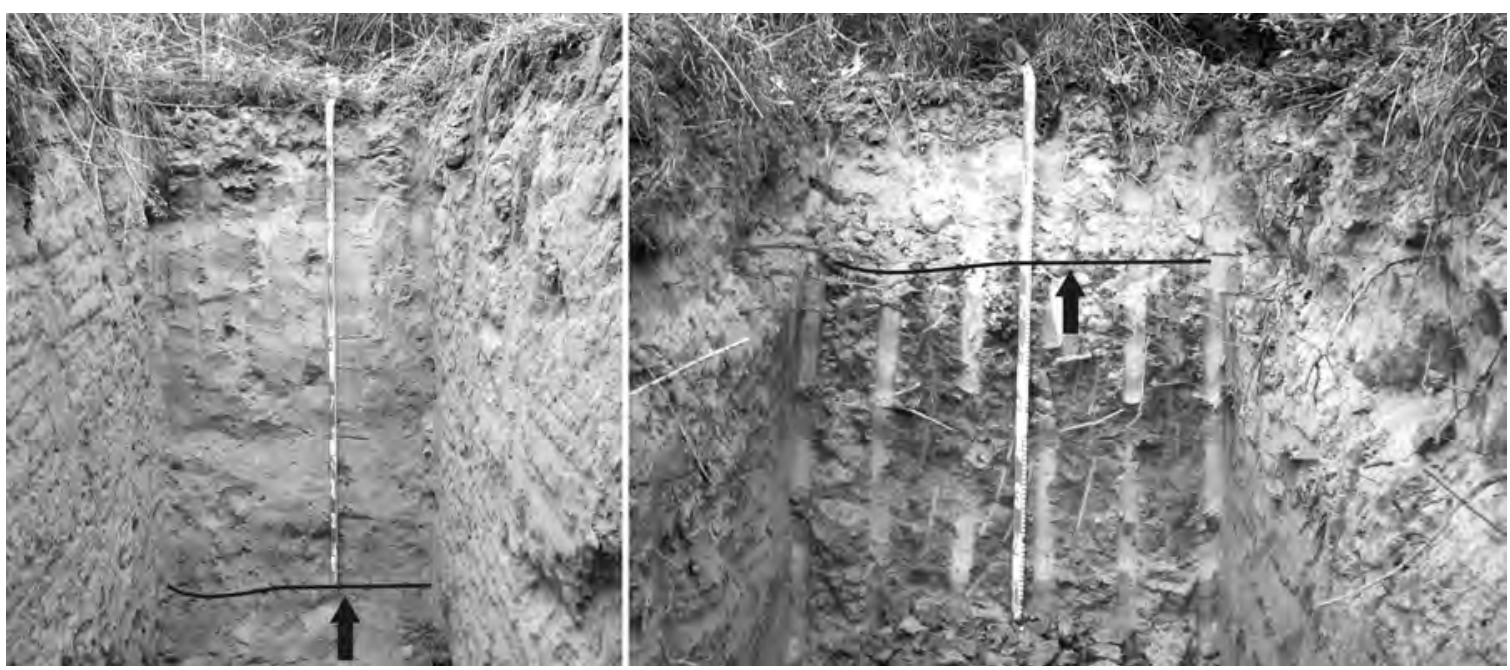

Figure 3-35. Examples of the varying depths of sandy sediments found at 41BP121. Arrows and black lines indicate the tops of the clay substratum at ca. 155 and 35 cmbs at BHTs 1 (left, looking south) and 3 (right, looking north), respectively.

natural gravels were exposed lying on top of the underlying reddish clay substratum in the 50-60 cmbs road cut. Together, all of this work and observations reveal the uneven depth of sandy sediments overlying the site (Figure 335). Also, some portion of the site is exposed in the road cut for the New Road. The size of this area is unknown but likely to be quite small as a percentage of the overall site area.

On the basis of these observations along with results of the shovel tests, a total of three backhoe trenches were excavated in 2005 near STs 5, 10, and in Area B. Backhoe trench profiles were described for each and are provided below followed by a photograph of the profile described (Figures 3-36 to 3-38). The sediments observed in the backhoe trenches reveal a $2 \mathrm{Bt}$ horizon at 160,53 , and $37 \mathrm{cmbs}$ in BHTs 1, 2, and 3, respectively. In the deeper Profile 1, a buried A horizon was documented between 79 and 112 cmbs. The presence of this horizon suggests a brief exposure of sediments and deposition of sands above this buried A horizon.

\section{Description of sediments in BHT 1 (Profile 8) 41BP121}

Zone 1: 0-31 cmbs, pale brown (10YR6/3) friable fine sandy loam, thick grass cover on surface, common rootlets that decrease down profile, small ( $\leq 12 \mathrm{~mm}$ ) ironstone pebbles ( $<1$ percent), gradual smooth lower boundary, A horizon.

Zone 2: 31-79 cmbs, light gray (10YR7/2) friable fine sandy loam, rare rootlets, few insect burrows, small $(\leq 12 \mathrm{~mm})$ ironstone pebbles ( $<1$ percent), clear smooth lower boundary, E horizon.

Zone 3: 79-112 cmbs, pale brown (10YR6/3) friable fine sandy loam, very few rootlets, few rootlets, chert pebbles $(5 \mathrm{~cm}$ maximum dimension); fire-cracked rock at 105 cmbs, clear smooth lower boundary, Ab horizon.

Zone 4: 112-138 cmbs, pale brown (10YR6.5/3) friable to slightly firm fine sandy loam, few rootlets and chert, petrified wood, and quartzite pebbles, clear smooth lower boundary, B1 horizon. 


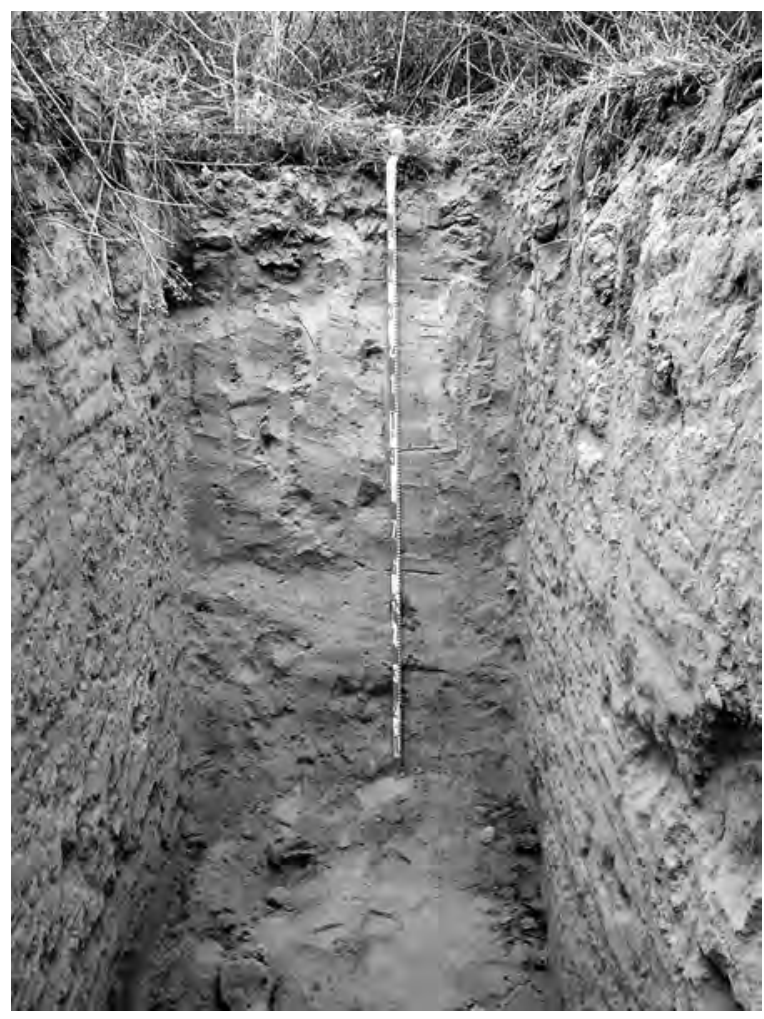

Figure 3-36. Profile 8 in BHT 1 at 41BP121.

Zone 5: 138-160 cmbs, very pale brown (10YR7/3) friable fine sandy loam, very few rootlets, abrupt irregular lower boundary, B2 horizon.

Zone 6: 160-180+ cmbs, strong brown (7.5YR4/6 to 5/6) very firm medium sandy clay loam, lower boundary not observed, 2Bt2.

\section{Description of sediments in BHT 2 (Profile 9) 41BP121}

Zone 1: 0-9 cmbs, yellowish brown (10YR5.5/4) loose fine sandy loam, thick grass and weed cover on surface, very common rootlets, few roots, abrupt smooth to wavy lower boundary, Ap horizon.
Zone 2: 9-49 cmbs, pale brown (10YR6/3) friable fine sandy loam, common rootlets, few roots and quartzite and petrified wood cobbles, scattered fire-cracked rock present, abrupt irregular lower boundary, A horizon.

Zone 3: 49-53 cmbs, very pale brown (10Y R8/3) friable fine sandy loam, clear smooth lower boundary, E horizon.

Zone 4: 53-100+ cmbs, yellowish red to pink (5YR5/8 to 7.5YR8/4) firm medium sandy clay loam, medium to strong medium subangular blocky structure, lower boundary not observed, 2Bt horizon.

\section{Description of sediments in BHT 3 (Profile 10) $41 B P 121$}

Zone 1: 0-9 cmbs, light gray (10YR7/2) loose fine sand, dense grass alternates with leaf litter cover, common rootlets, abrupt wavy lower boundary, O horizon.

Zone 2: 9-37 cmbs, Very pale brown (10YR8/2) friable fine sand, dense layer of quartzite and chert cobbles $\leq 15 \mathrm{~cm}$ diameter within sand,

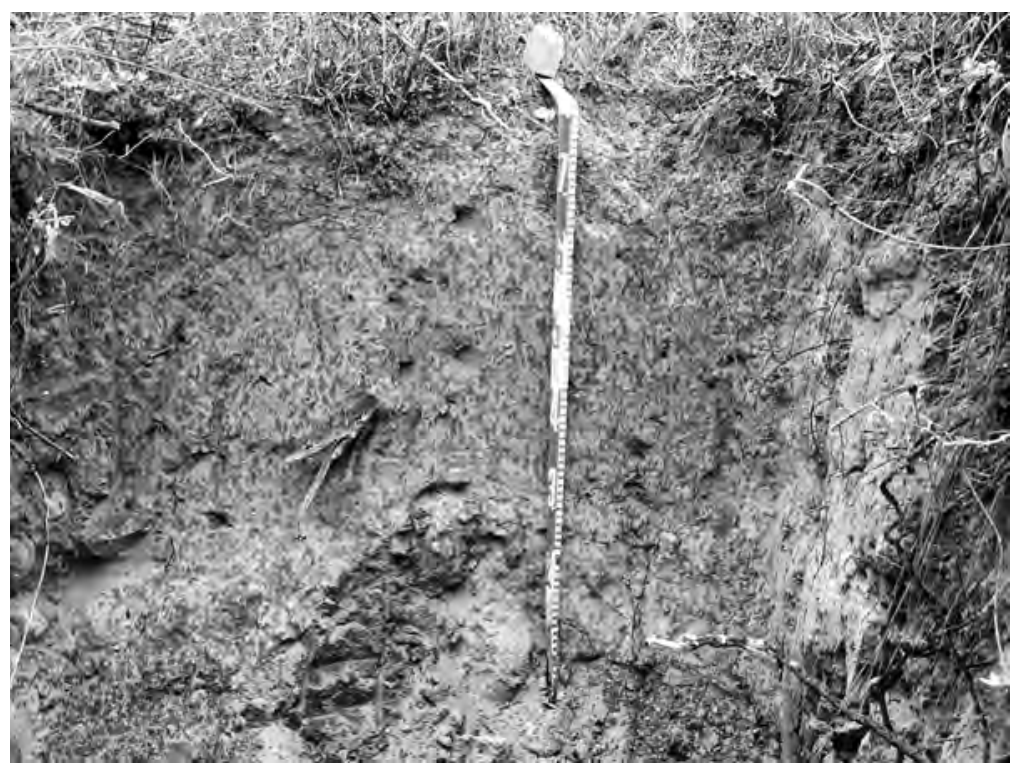

Figure 3-37. Profile 9 in BHT 2 at 41BP121. 


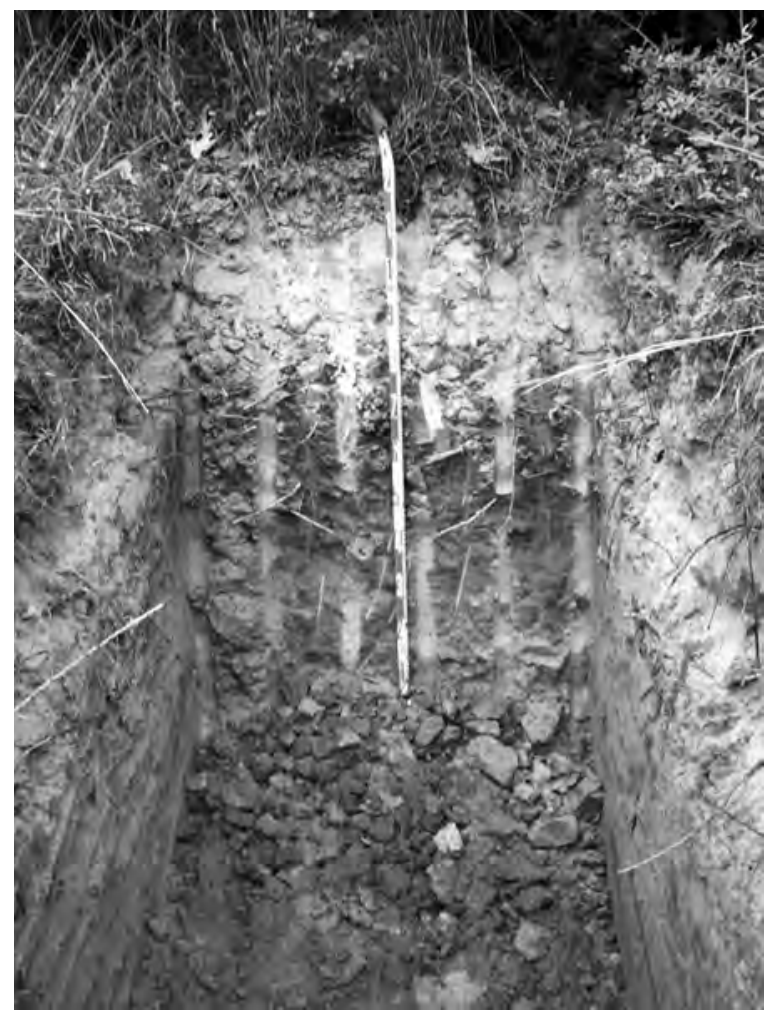

Figure 3-38. Profile 10 in BHT 3 at 41BP121.

few rootlets and roots, wavy to irregular lower boundary, E horizon.

Zone 3: 37-100+ cmbs, reddish yellow (7.5YR7/8) sandy clay loam, fine to medium strong subangular blocky structure, lower boundary not observed, 2Bt horizon.

Consistent artifact occurrences were noted between 70 and 90 cmbs in BHT 1 (Table 3-5). Debitage and fire-cracked rocks were observed in light to moderate concentrations (fewer than 10 pieces) from both ends of the trench. Additionally, fire-cracked rocks were present in nearby BHT 2 as well. It is possible that the fire-cracked rock represented features. Also, it is possible that these finds are part of the same archaeological component that covers the area extending between the two trenches. This is the part of the site that Nickels and Lehman (2004b) believe to have been originally examined by Skelton and Freeman (1979). No artifacts were noted in BHT 3 located in Area $\mathrm{A}$, the area of the site identified and described by Robinson (2001). Based on the results of the current work, taken together with the previous excavations that are described above, Area B appears to hold clear potential to contain additional, intact prehistoric deposits. The age of this site is currently unknown. On the basis of artifacts observed during the current phase of research, its original assessment as an open campsite is supported.

As few artifacts and no features were observed in Area A, this portion of the site is not considered potentially eligible for listing to the NRHP and no further work is recommended in this area. However, Area B may have features and a great enough artifact density to provide useful information, and Area B is recommended as potential eligibility for listing to the NRHP. Further investigations are recommended for Area B.

Table 3-5. Approximate depths of artifact recovery from backhoe trenches at 41BP121. When no depth could be recorded, artifact depth is listed as "unknown.”

\begin{tabular}{|c|c|c|c|c|c|c|}
\hline Trench & $\begin{array}{c}\text { Bottom } \\
\text { Elevation } \\
\text { (cmbs) }\end{array}$ & $\begin{array}{c}\text { Clay } \\
\text { Reached? }\end{array}$ & $\begin{array}{c}\text { Debitage } \\
\text { (cmbs) }\end{array}$ & $\begin{array}{c}\text { Charcoal } \\
\text { (cmbs) }\end{array}$ & $\begin{array}{c}\text { FCR } \\
\text { (cmbs) }\end{array}$ & $\begin{array}{c}\text { Others } \\
\text { (cmbs) }\end{array}$ \\
\hline BHT 1 & 190 & yes & $70-90$ & - & $70-90$ & - \\
\hline BHT 2 & 100 & yes & - & - & 40 & - \\
\hline BHT 3 & 100 & yes & - & - & - & - \\
\hline
\end{tabular}




\section{BP471}

This site is located on an open sideslope below a rounded knoll on the east side of an intermittent upper tributary of Big Sandy Creek. A constantly-flowing spring-fed drainage is located a hundred meters to the south. The site area is currently an open field with a heavy mixture of tall grasses, weed, and prickly pear ground cover. Patila complex soils cover the site area. The eastern end of the site has been disturbed by the construction of Wine Cellar Road. A cedar fence post in the center of the site indicates that historic property lines may have crossed the site area as well (Figure 3-39).

The site was initially recorded in 1996 by Sullo and Wormser (1996), who excavated 13 shovel tests (four contained cultural materials), recovering 10 flakes. In their 2002-2003 revisit, Nickels and Lehman (2004b:60) describe it as a prehistoric open campsite containing fire-cracked rock and lithic debitage. That effort included 26 shovel tests, which yielded 28 pieces of large $(>1$ inch) and small ( $<1$ inch) firecracked rock, over 30 pieces of chert debitage, two utilized flakes, a hammerstone, and a piece of charcoal. Cultural deposits were identified up to 130 cmbs; many of the shovel tests stopped at 100 cmbs without reaching the underlying red sandy clay loam substratum. Based on their results, Nickels and Lehman (2004b:62) recommended that five backhoe trenches be excavated close to STs $1,7,14,15$, and 26 (see Figure 3-39).

During the 2005 field season, five backhoe trenches were excavated. Backhoe trench profiles were described for each and are provided below followed by a photograph of the profile described (Figures 3-40 to 3-44). In BHTs 1, 3 and 4, a 2Bt horizon was encountered at 103, 109, and $127 \mathrm{cmbs}$, respectively. Two distinguishable clay lamella Bt horizons were observed in BHT 2 between 90 and 170 cmbs, and A-B horizons were documented in BHT 1 extending to $103 \mathrm{cmbs}$, in BHT 2 extending to $90 \mathrm{cmbs}$, in BHT 3 extending to $109 \mathrm{cmbs}$, in

\section{FIGURE 3-39. REDACTED}

Figure 3-39. Map of 41BP471 showing locations of backhoe trenches and 2002-2003 shovel tests (adapted from Nickels and Lehman 2004b: Figure 4-36). 
BHT 4 extending to 127 cmbs, and in BHT 5 to a depth of 70 cmbs. No stratigraphic breaks were observed in the sandy A$\mathrm{B}-\mathrm{Bt}$ horizons above the $2 \mathrm{Bt}$ horizon.

\section{Description of sediments in BHT 1 (Profile 19) 41BP471}

Zone 1: 0-10 cmbs, pale brown (10YR6/3) loose fine sandy loam, common rootlets, clear smooth lower boundary, Ap horizon.

Zone 2: 10-75 cmbs, pale brown

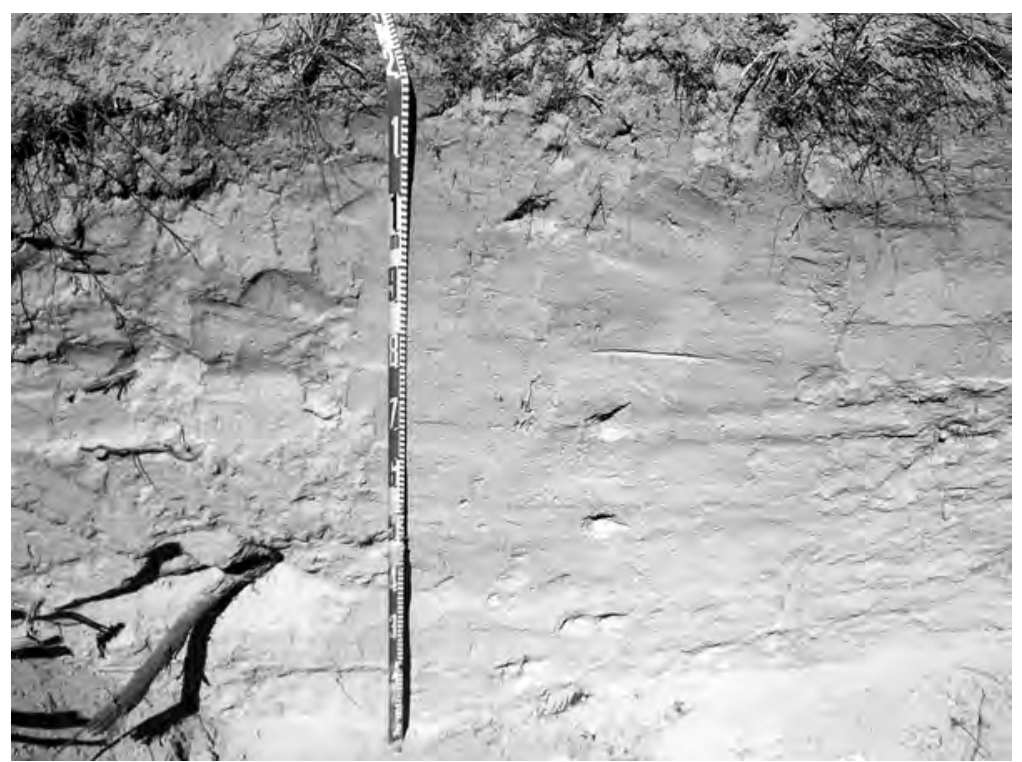

Figure 3-40. Profile 19 in BHT 1 at 41BP471.
(10YR6/3) massive friable fine sandy loam, few rootlets, gradual smooth lower boundary, B1 horizon.

Zone 3: 75-103 cmbs, very pale brown (10YR7/3) friable fine sandy loam, slightly more firm than Zone 2, very abrupt smooth lower boundary, B2 horizon.

Zone 4: 103+ cmbs, Yellowish brown (5YR5/6) very firm medium to coarse sandy clay loam, lower boundary not observed, 2Bt horizon.

\section{Description of sediments in BHT 2 (Profile 20) $41 B P 471$}

Zone 1: 0-20 cmbs, pale brown (10YR6/3) loose fine sandy loam, common rootlets, clear smooth lower boundary, Ap horizon.

Zone 2: $20-90$ cmbs, pale brown (10YR6/3) massive friable fine sandy loam, few rootlets, clear smooth lower boundary, B horizon.

Zone 3: $90-170$ cmbs, pale brown (10YR6/3) massive friable fine sandy loam, $8^{+}$strong brown (7.5YR5/6) thin 1-3 mm clay lamellae, abrupt wavy lower boundary, Bt1 horizon.
Zone 4: $170-240+$ cmbs, very pale brown (10YR7/3) massive friable fine sandy loam, clay lamellae as in Zone 3, up to $10 \mathrm{~mm}$ in thickness, fire-cracked rock at $220 \mathrm{cmbs}$, lower boundary not observed, Bt2 horizon.

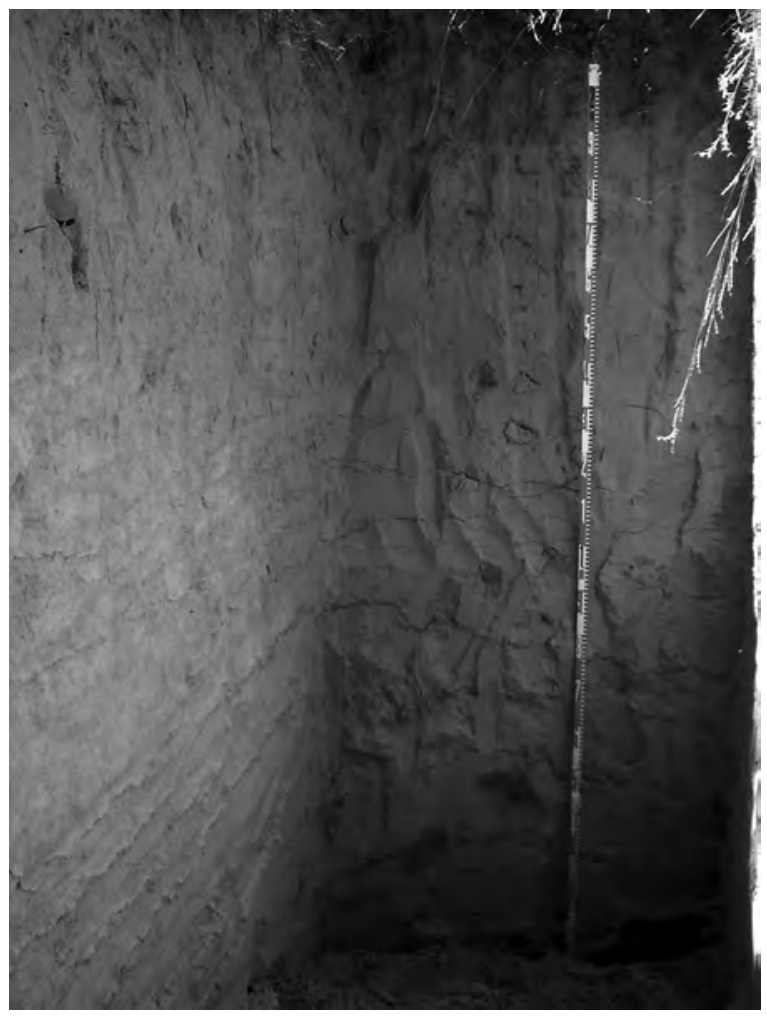

Figure 3-41. Profile 20 in BHT 2 at 41BP471. 


\section{Description of sediments in BHT 3 (Profile 21) 41BP471}

Zone 1: 0-25 cmbs, pale brown (10YR6/3) loose fine sand, dense grass cover, abundant rootlets, clear smooth lower boundary, Ap horizon.

Zone 2: 25-85 cmbs, very pale brown (10YR7/3) massive friable fine sandy loam, gradual smooth lower boundary, B1 horizon.

Zone 3: 85-109 cmbs, very pale brown (10YR8/3) friable fine sandy loam, abrupt irregular lower boundary, B2 horizon.

Zone 4: 109+ cmbs, brownish yellow to reddish yellow (10YR6/8 to 7.5YR6/8) very firm medium sandy clay loam, medium moderate subangular blocky structure, lower boundary not observed, 2Bt horizon.

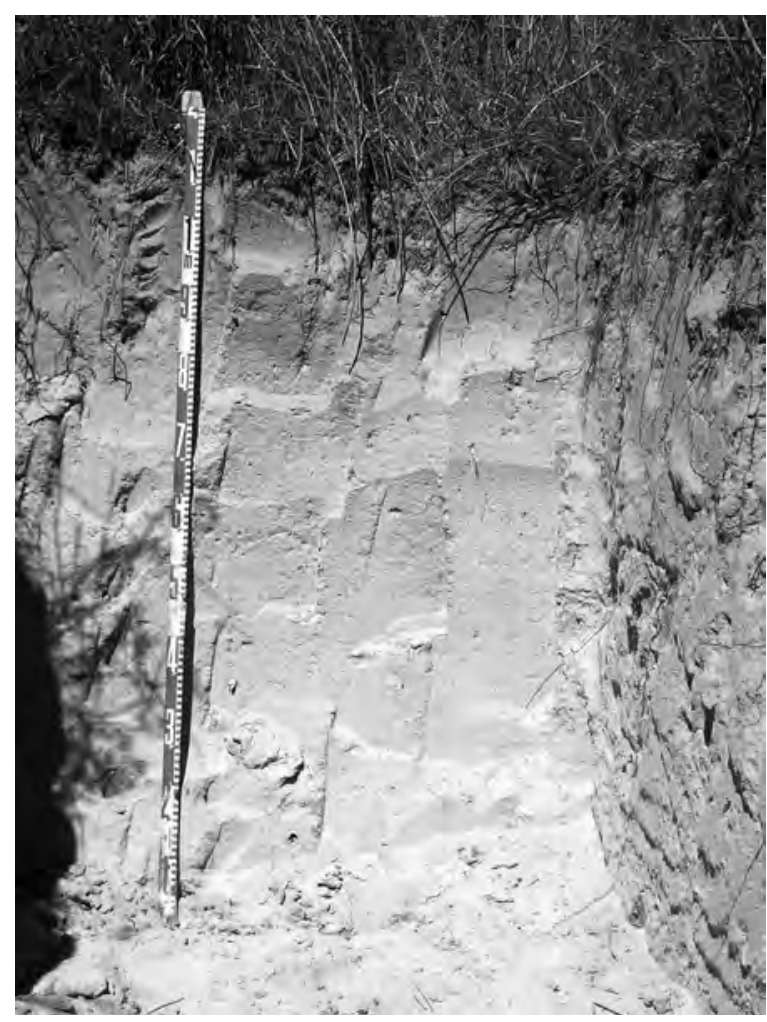

Figure 3-42. Profile 21 in BHT 3 at 41BP471.

\section{Description of sediments in BHT 4 (Profile 22) 41BP471}

Zone 1: 0-24 cmbs, very pale brown (10YR7/3) loose fine sandy loam, common rootlets, clear smooth lower boundary, Ap horizon.

Zone 2: 24-127 cmbs, very pale brown (10YR7/3) massive friable fine sandy loam, few rootlets, very abrupt smooth to wavy lower boundary, B horizon.

Zone 3: 127+ cmbs, strong brown (7.5YR5/8) firm medium sandy clay loam, lower boundary not observed, 2Bt horizon.

\section{Description of sediments in BHT 5 (Profile 23) 41BP471}

Zone 1: 0-18 cmbs, pale brown (10YR6/3) fine sandy loam, common rootlets, clear smooth lower boundary, Ap horizon.

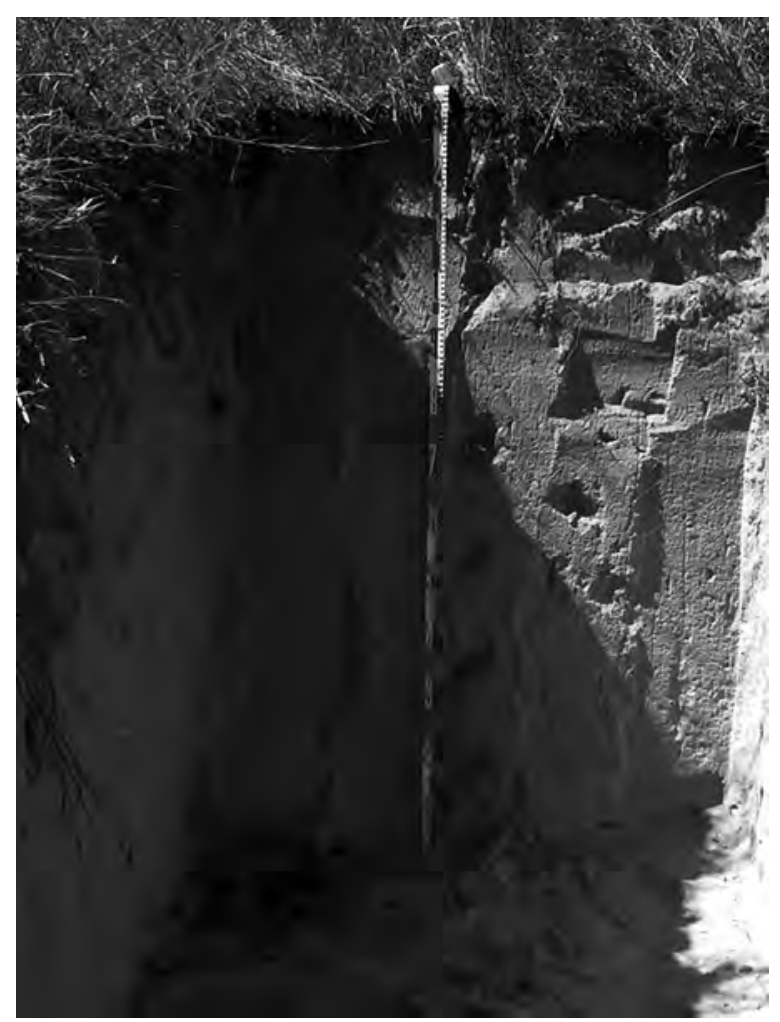

Figure 3-43. Profile 22 in BHT 4 at 41BP471. 
Zone 2: 18-70+ cmbs, very pale brown (10YR7/3) friable fine sandy loam, few roots; strong brown 7.5YR5/6 discoloration that is probably a rodent burrow 27-32 cmbs and $10 \mathrm{~cm}$ in diameter, burned rock cluster feature at $60-65 \mathrm{cmbs}$, lower boundary not observed, B horizon.

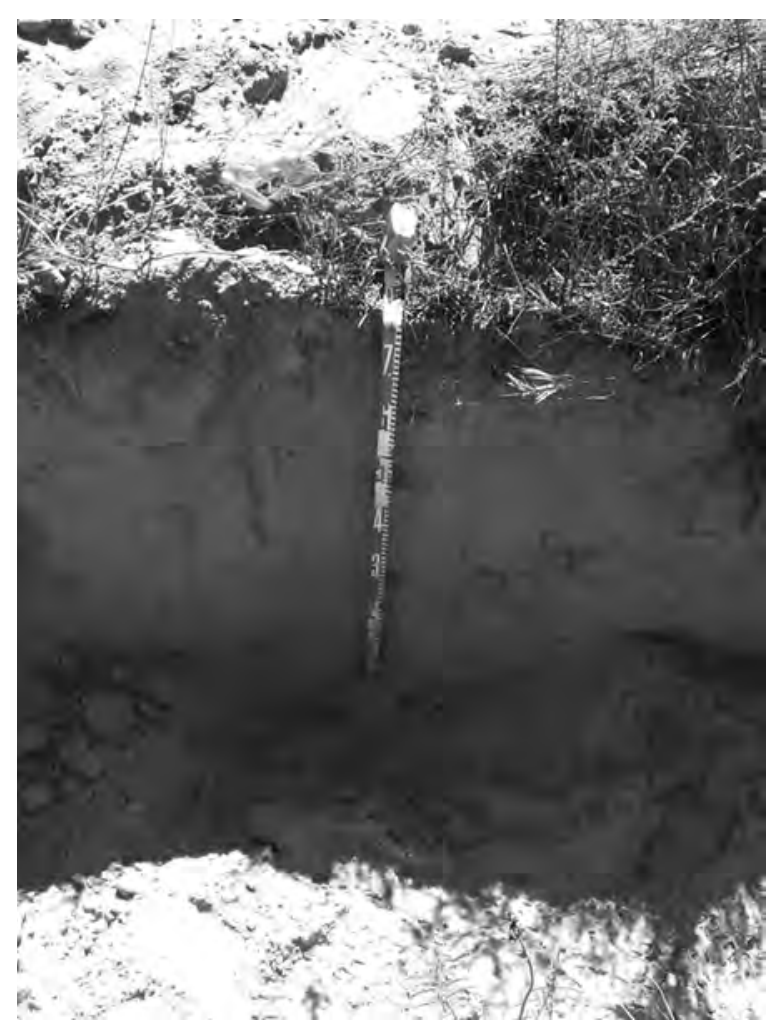

Figure 3-44. Profile 23 in BHT 5 at 41BP471.
The area covered by 41BP471 is quite large $\left(25,693 \mathrm{~m}^{2}\right)$, and a variety of different kinds of cultural materials were recorded in BHTs 1, 2, 4, and 5 , including a possible hammerstone from the final backhoe trench. No artifacts were observed in BHT 3 despite the fact that it was surrounded by positive shovel tests from previous excavations (Table 3-6). A very loose cluster of three burned or fire-cracked rocks was recorded in BHT 1. The reconstructed extent of this cluster is quite small, covering an area less than $50 \mathrm{~cm}$ in extent (Figure 3-45). Two of the cobbles were recovered from the same bucketload of trench sediments, leading to the conclusion that these rocks were originally in close association with each other. These stones were located approximately $40 \mathrm{cmbs}$ near the east end of the trench, close to Wine Cellar Road. No other cultural materials were observed from the trench. This cluster was disturbed by the backhoe bucket, which dislodged two of the three rocks. CAS archaeologists believe these three quartzite cobbles were probably originally in association and would in other circumstances have warranted designation as a feature. However, the limited extent of this deposit, the small number of stones that it contained, and its highly disturbed context preclude designating this small cluster as a feature. Instead, it merely provides evidence of burning or fire-making activities at the site.

Table 3-6. Approximate depths of artifact recovery from backhoe trenches at 41BP471. When no depth could be recorded, artifact depth is listed as “unknown.”

\begin{tabular}{|c|c|c|c|c|c|c|}
\hline Trench & $\begin{array}{c}\text { Bottom } \\
\text { Elevation } \\
\text { (cmbs) }\end{array}$ & $\begin{array}{c}\text { Clay } \\
\text { Reached? }\end{array}$ & $\begin{array}{c}\text { Debitage } \\
\text { (cmbs) }\end{array}$ & $\begin{array}{c}\text { Charcoal } \\
\text { (cmbs) }\end{array}$ & $\begin{array}{c}\text { FCR } \\
\text { (cmbs) }\end{array}$ & $\begin{array}{c}\text { Others } \\
\text { (cmbs) }\end{array}$ \\
\hline BHT 1 & 100 & yes & & & 40 & \\
\hline BHT 2 & 240 & no & $\begin{array}{c}\text { burned chert } \\
\text { (n=1) at 130-150 }\end{array}$ & & $\begin{array}{c}50,80, \\
130-150\end{array}$ & \\
\hline BHT 3 & 100 & yes & & & & \\
\hline BHT 4 & 130 & yes, & flake at 50 & & $50-60$ & \\
\hline BHT 5 & 80 & no & 60 & 60 & & $\begin{array}{c}\text { possible quartzite } \\
\text { hammerstone at 50; } \\
\text { Feature 1 at 60 }\end{array}$ \\
\hline
\end{tabular}


Feature 1 consisted of a very large number $(n>30)$ of heated and fire-cracked rocks exposed in BHT 5 (Figure 3-46). This loose cluster of small (under $8 \mathrm{~cm}$ ) rocks was disturbed by the backhoe bucket (Figure 3-47), but measured approximately $80 \mathrm{~cm}$ across (east-west). The feature continues into the south wall of the backhoe trench, making it impossible to record its full dimensions. Feature 1 was recorded approximately $60 \mathrm{cmbs}$ in the southwest end of the trench. In the northeast end of the trench, approximately five meters from and at the same depth as Feature 1, a faintly burned and discolored area of sand was exposed. No firecracked rocks were present, however, making it difficult to identify this possible burn stain as a prehistoric feature with complete confidence. Two small chert flakes were located at this depth and directly adjacent to the discolored sandy sediments, indicating that intact activity areas might be present around Feature 1.

In addition to the feature and small cluster of burned rock described above, BHT 2 contained cultural materials at depths consistently

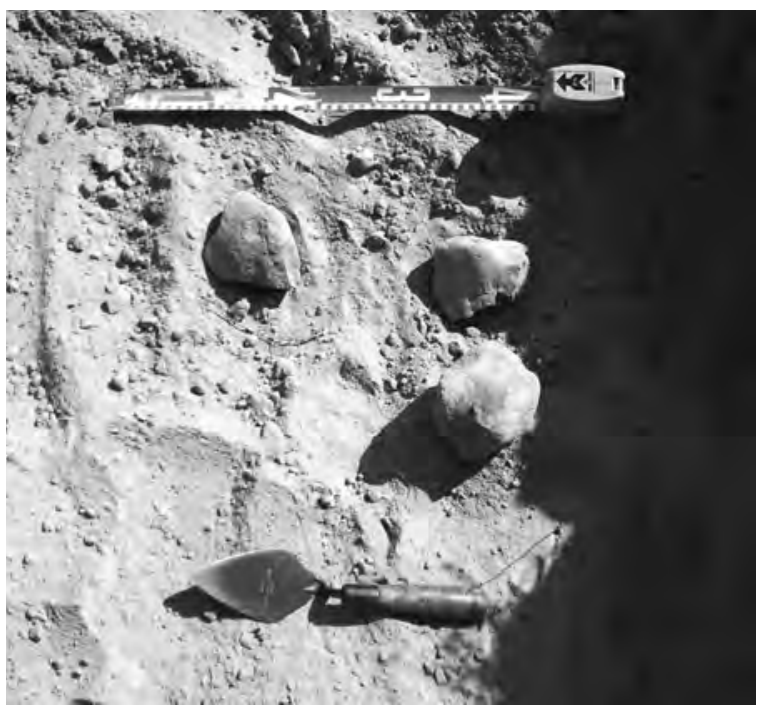

Figure 3-45. Small cluster of large fire-cracked rocks from BHT 1 at 41BP471. The rock at left is in situ while two rocks on the right have been replaced; their exact original position is unknown. This cluster is not considered to be a cultural feature.

ranging between 50-80 and 130-150 cmbs from both the southwest and northeast ends of the trench. These remains included small and large fire-cracked rocks, burned chert, and a large manganese stone that appears to have been carried onto the site by its prehistoric
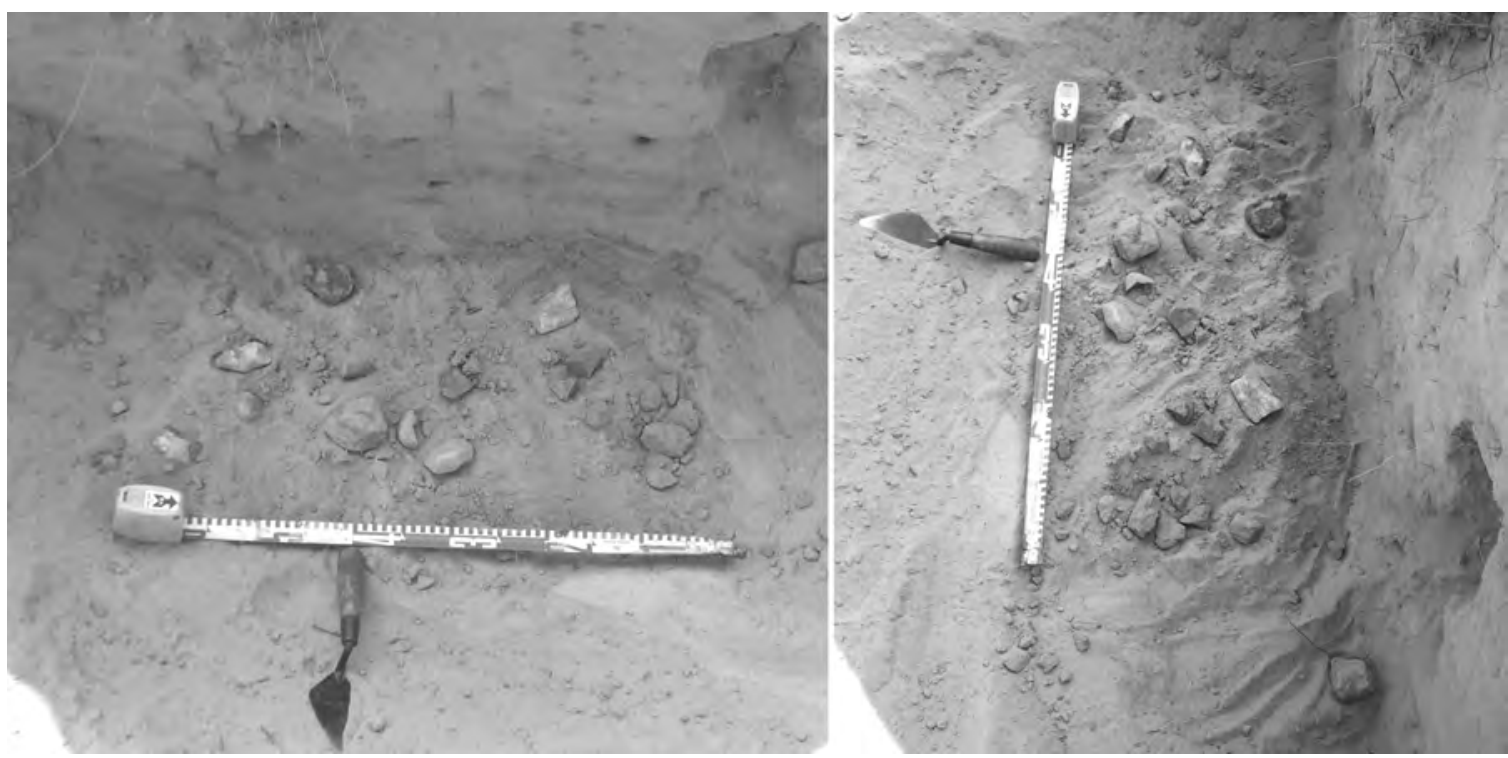

Figure 3-46. Feature 1, recorded in BHT 5, looking south (left) and east (right). This cluster of fire-cracked rock was exposed by the backhoe bucket. 


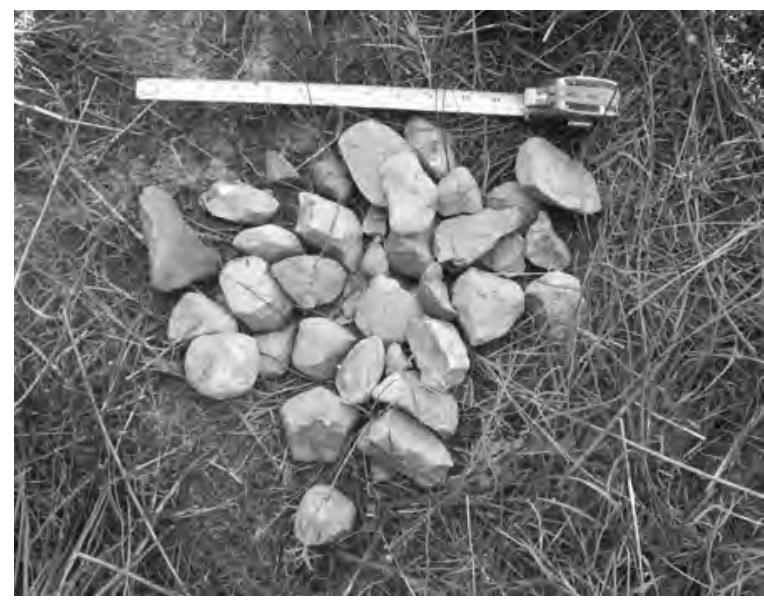

Figure 3-47. Fire-cracked rocks from Feature 1, BHT 5 at 41BP471, that were disturbed by the backhoe bucket. Scale is extended approximately $40 \mathrm{~cm}$.

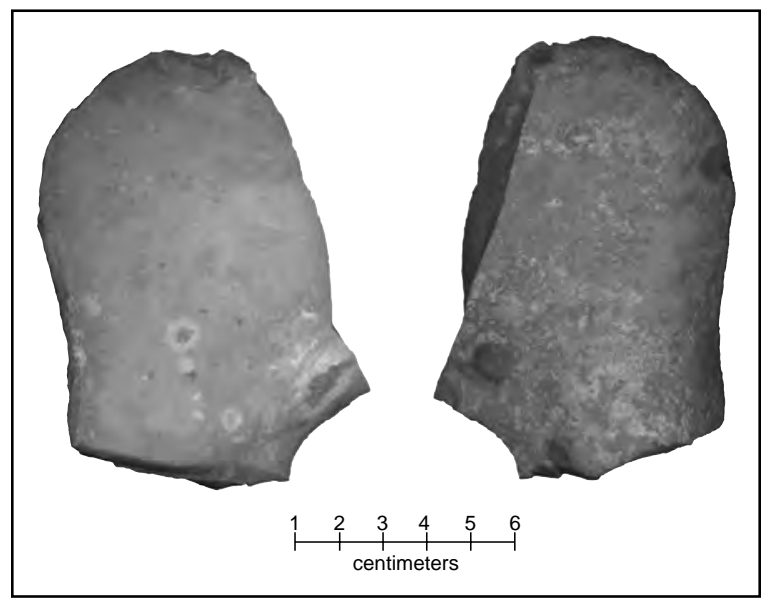

Figure 3-48. Large chert flake recorded at $50 \mathrm{cmbs}$ in BHT 4 at 41BP471. Interior view (left) and dorsal, cortex view (right).

occupants. While manganese nodules occur naturally in these settings, no other gravels or clasts were found at this depth that would indicate geologic mechanisms of transport and deposition. On the basis of these finds, this part of the site is believed to contain two intact, stratified components that are separated by approximately 50 or more centimeters of sandy sediments.

Backhoe Trench 4 revealed underlying red clay substratum at approximately 120 cmbs.
Cultural remains were recorded at between 50 and $60 \mathrm{cmbs}$ from both the west and east ends of the trench. A very large chert flake was documented from the west end (Figure 3-48). This flake, completely covered with cortex on its dorsal side, appears to have been sheared off from a river cobble. The material is fine to medium-fine grained, light gray brown chert with small circular inclusions. The material resembles the same type as the large flake core reported from BHT 1 at 41BP111 (see Figure 3-17). The striking platform is completely crushed, and the flake was split long-wise when it was removed from the original cobble. As with the flake core from 41BP111, it is suggested that this large flake, or the core from which it was struck, could have been transported from off-site as part of a strategy for leveling or equalizing lithic resource availability across different zones of a seasonally mobile settlement-subsistence pattern. While this behavior is suggested by these data, more integrated lithic sourcing studies will be required both within Camp Swift and in nearby areas before archaeologists fully understand prehistoric mobility patterns.

This site is one of the largest that was tested in the current phase of investigations at Camp Swift. At least one intact feature is present and an abundance and diversity of artifacts were noted, though the site can not yet be dated by available evidence. CAS archaeologists consider it to have been an open campsite composed of at least one and possibly multiple components. As such, it clearly contains the potential to yield additional information about prehistoric occupations of Camp Swift. This site is considered potentially eligible for listing to the NRHP and additional work is recommended. 


\section{BP491}

This site, recorded during the TXARNG survey (Robinson 2001), is found in a heavily wooded upland setting overlooking an intermittent tributary of Big Sandy Creek. The site is covered by Silstid loamy fine sand soils. Nickels and Lehman (2004b:68) describe the site as a prehistoric open campsite with firecracked rock and associated lithic debitage. A multicomponent prehistoric site, 41BP495, lies only $30 \mathrm{~m}$ to the southeast, and it is possible that the two sites are in actuality different areas of the same general occupation area.

During the site's initial recording, archaeologists excavated three shovel tests and recovered five pieces of burned rock and two flakes. In the revisit and reassessment by Nickels and Lehman (2004b), CAS archaeologists excavated 23 shovel tests, recovering 15 pieces of fire-cracked rock (including both large and small sizes), 17 pieces of debitage, and a retouched flake. The deepest shovel test extended to $120 \mathrm{cmbs}$, while most were terminated at $100 \mathrm{cmbs}$. Only five shovel tests reached the underlying clay substratum; all the rest terminated in sandy sediments, indicating that the lower reaches of the cultural material in this landform can be quite deep. Based on the findings of the 2002-2003 CAS work, three backhoe trenches were recommended, located near STs 6 and 7, 11 and 21, and 18 (Figure 3-49).

\section{In 2005 CAS excavated three backhoe trenches.}

Backhoe trench profiles were described for each and are provided below followed by a photograph of the profile described (Figures 3-50 to 3-54). In all backhoe trenches, A and B horizons were documented to depths of 144, 140, and 70 cmbs in BHTs 1 to 3, respectively. Bt horizons with clay lamellae were observed between 144-240 and 70-170 cmbs in BHTs 1 and 3. No underlying 2Bt horizons were documented.

\section{Description of sediments in BHT 1 (Profile 28) 41BP491}

Zone 1: 0-8 cmbs, brown (10YR5/3) loose fine sandy loam, moderate leaf litter cover at surface, common rootlets, few roots, abrupt wavy to irregular, A1 horizon.

Zone 2: 8-29 cmbs, pale brown (10YR6/3) loose fine sandy loam, few rootlets and roots, clear smooth lower boundary, A2 horizon.

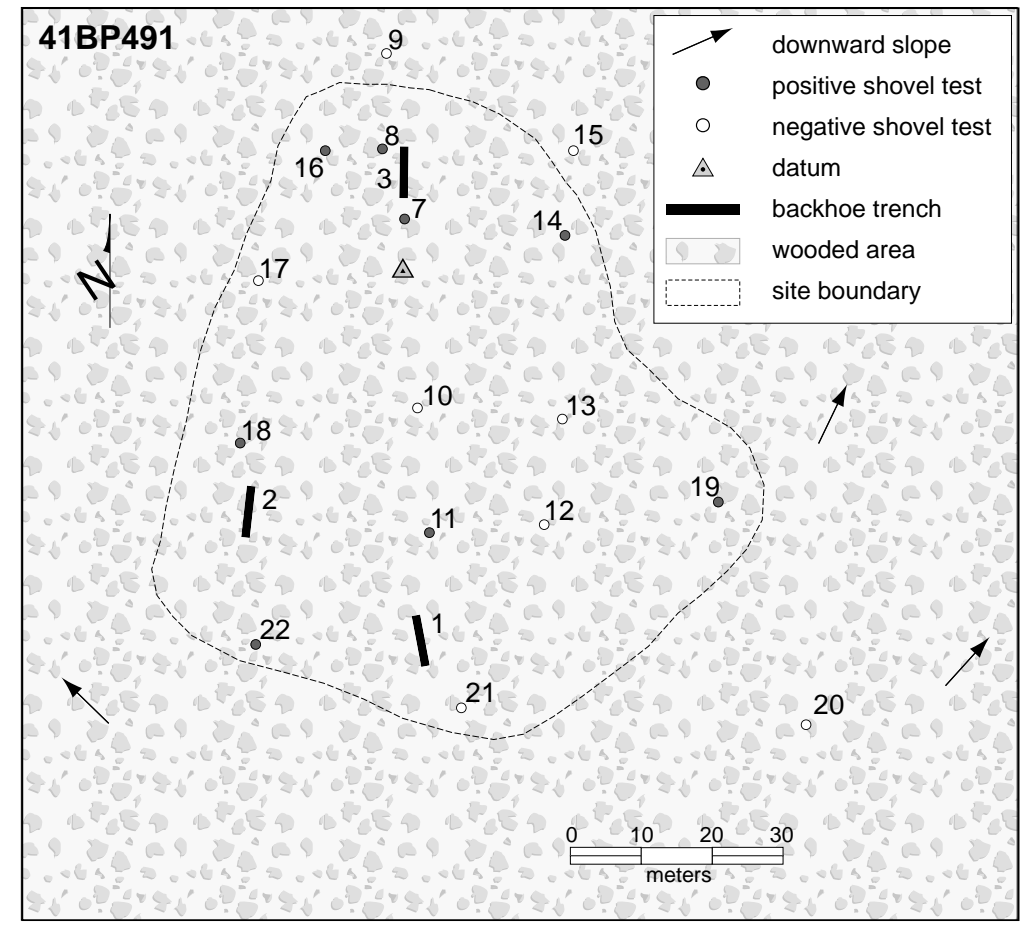

Figure 3-49. Map of 41BP491 showing locations of backhoe trenches and 2002-2003 shovel tests (adapted from Nickels and Lehman 2004b: Figure 4-41). 
Zone 3: 29-75 cmbs, pale brown (10YR6/3) friable fine sandy loam, common rootlets, few roots and insect burrows, gradual smooth lower boundary, AB horizon.

Zone 4: 75-144 cmbs, very pale brown (10YR7/3) massive friable fine sandy loam, common rootlets, few roots and insect burrows; clay lamellae are 1-2 microns thin at top of zone, clear smooth lower boundary, B horizon.

Zone 5: $144-240+$ cmbs, very

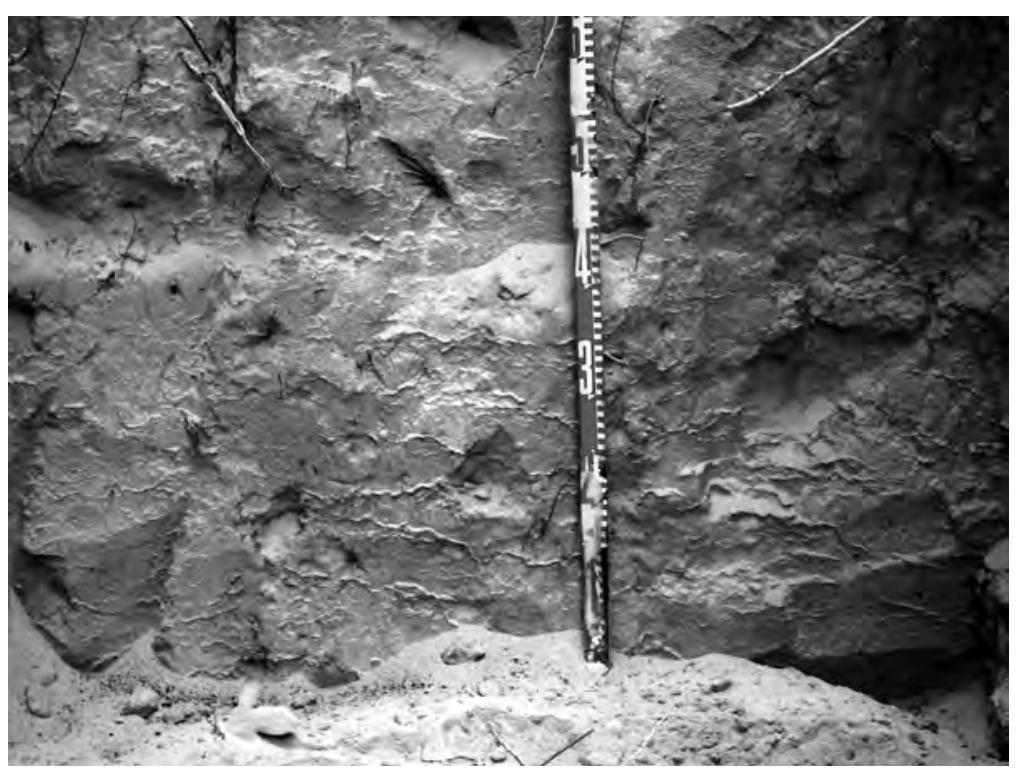

Figure 3-50. Zone 5 of Profile 28 in BHT 1 at 41BP491. pale brown (10YR7/3) massive friable fine sandy loam, few rootlets, rare roots; fire-cracked rock between

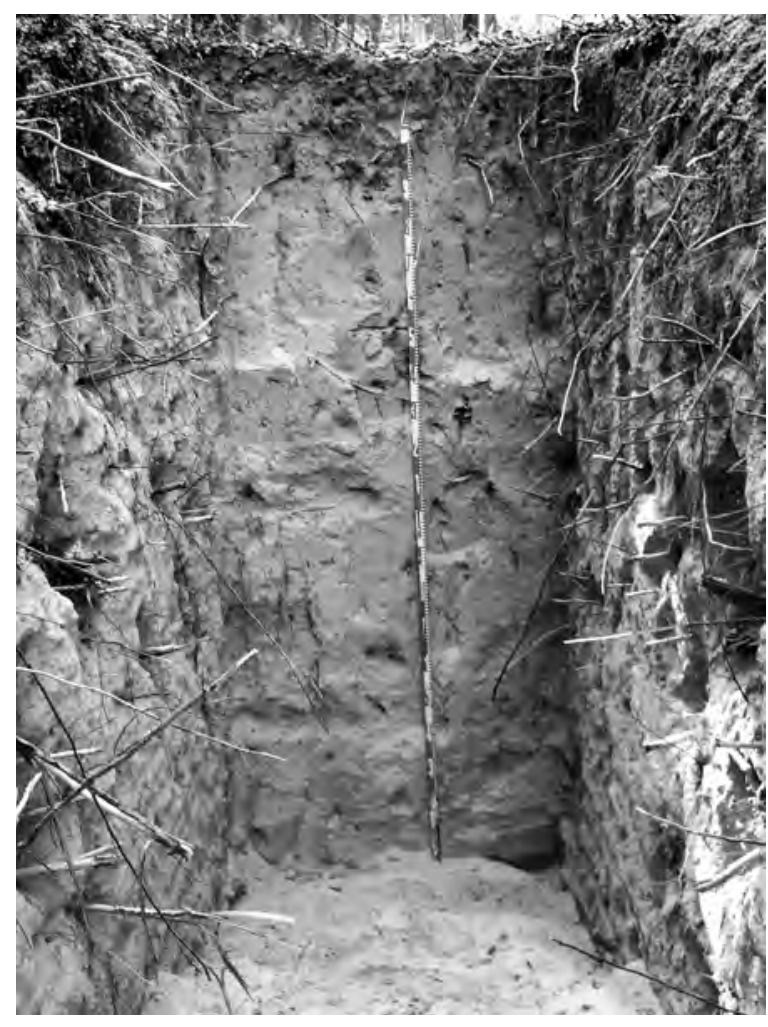

Figure 3-51. Profile 28 in BHT 1 at 41BP491.

200 and 215 cmbs; very many extremely thin $(0.5 \mathrm{~mm})$ faint strong brown $(7.5 \mathrm{YR} 5 / 6)$ clay lamellae that increase up to $2 \mathrm{~mm}$ in thickness down profile, lower boundary not observed, $\mathrm{Bt}$ horizon.

\section{Description of sediments in BHT 2 (Profile 29) 41BP491}

Zone 1: 0-11 cmbs, brown (10YR5/3) loose fine sandy loam, common roots and rootlets, abrupt smooth lower boundary, A horizon.

Zone 2: 11-51 cmbs, light yellowish brown (10YR6/4) slightly friable fine sandy loam, common roots and rootlets, clear smooth lower boundary, AB horizon.

Zone 3: 51-103 cmbs, very pale brown (10YR7/4) massive friable fine sandy loam, few roots, rootlets, and insect burrows, gradual smooth lower boundary, B1 horizon.

Zone 4: 103-140+ cmbs, very pale brown (10YR7/3) slightly friable fine sandy loam, rare roots, few rootlets, lower boundary not observed, B2 horizon. 


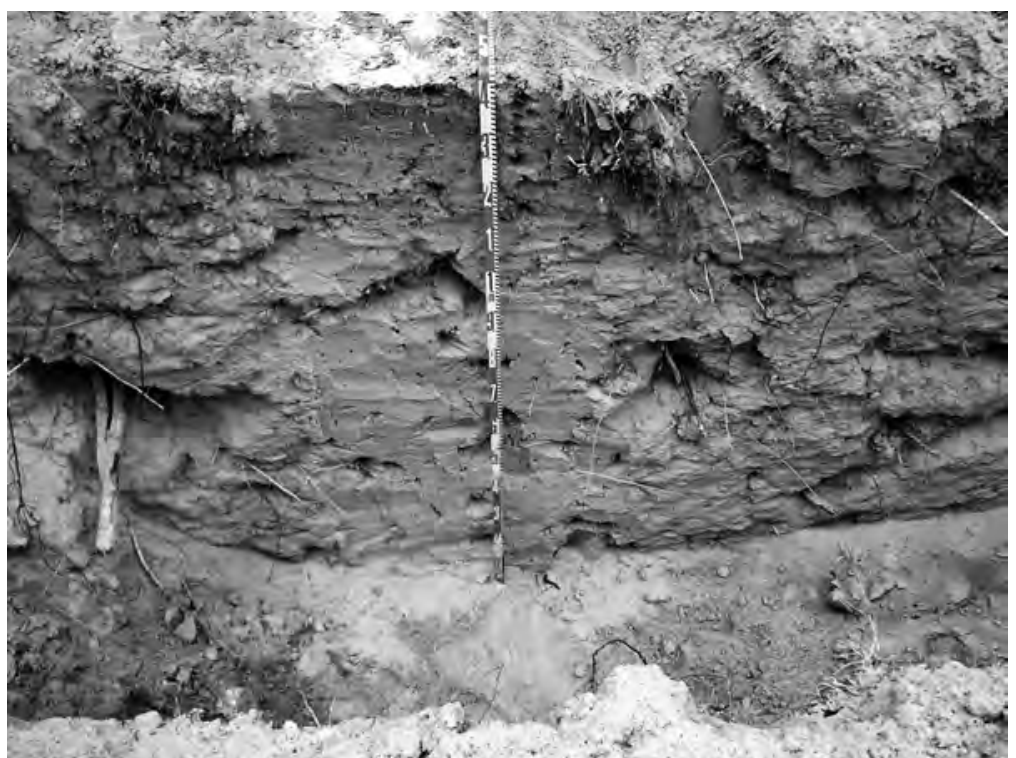

Figure 3-52. Profile 29 in BHT 2 at 41BP491.

\section{Description of sediments in BHT 3 (Profile 30) 41BP491}

Zone 1: 0-8 cmbs, brown (10YR5/3) loose fine sandy loam, moderate grass cover at surface, common rootlets, common roots, abrupt wavy to irregular, A horizon.

Zone 2: 8-70 cmbs, light yellowish brown (10YR6/4) massive friable fine sandy loam, common rootlets, rodent burrows $(10-20 \mathrm{~cm}$ diameter) at 45 and $63 \mathrm{cmbs}$, clear smooth lower boundary, AB horizon.

Zone 3: 70-105 cmbs, light yellowish brown (10YR6/4) fine sandy loam, many very think $0.5-1 \mathrm{~mm}$ clay lamellae that increase in thickness and frequency down profile, clear smooth lower boundary, Bt1 horizon.

Zone 4: $105-170+$ cmbs, very pale brown (10YR7/4) fine sandy loam, few roots and rootlets, strong brown (10YR5/6) thin (1-3 mm) clay lamellae that increase in thickness and frequency down profile, lower boundary not observed, Bt2 horizon.
Backhoe Trench 1, aligned north-south, contained the most cultural materials of the three trenches excavated at this site (Table 3-7). Observations included small pieces of firecracked rock at depths of approximately 50, 130, 160, and 200 cmbs, all from the south end of the trench. The sandy sediments were extremely soft and loose, and the trench was halted at just over 220 cmbs without reaching the underlying red clay substratum (Figure 3-54). No lithic debitage was observed in BHT 2. Backhoe Trench 3 encountered slightly more compacted sediments in the upper

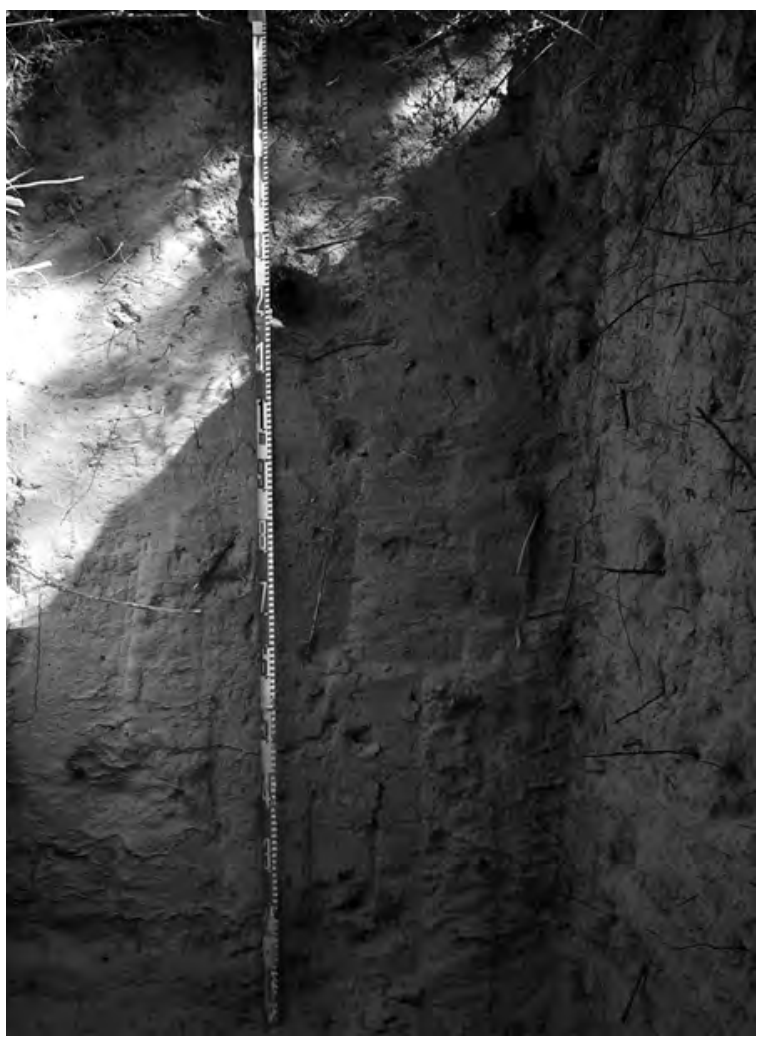

Figure 3-53. Profile 30 in BHT 3 at 41BP491. 
Table 3-7. Approximate depths of artifact recovery from backhoe trenches at 41BP491. When no depth could be recorded, artifact depth is listed as "unknown."

\begin{tabular}{|c|c|c|c|c|c|c|}
\hline Trench & $\begin{array}{c}\text { Bottom } \\
\text { Elevation } \\
\text { (cmbs) }\end{array}$ & $\begin{array}{c}\text { Clay } \\
\text { Reached? }\end{array}$ & $\begin{array}{c}\text { Debitage } \\
\text { (cmbs) }\end{array}$ & $\begin{array}{c}\text { Charcoal } \\
\text { (cmbs) }\end{array}$ & $\begin{array}{c}\text { FCR } \\
\text { (cmbs) }\end{array}$ & $\begin{array}{c}\text { Others } \\
\text { (cmbs) }\end{array}$ \\
\hline BHT 1 & 240 & no & & & $50,130,160,200$ & \\
\hline BHT 2 & 150 & no & & & & \\
\hline BHT 3 & 160 & no & & $120-130$ & 150 & \\
\hline
\end{tabular}

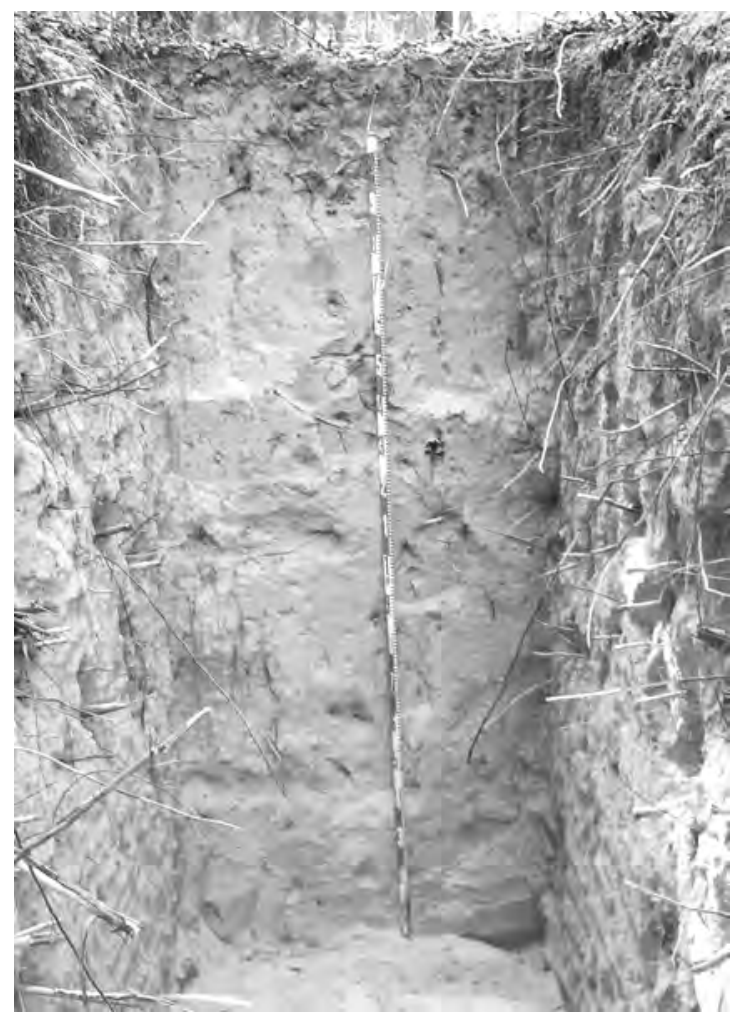

Figure 3-54. Depth of sandy sediments in BHT 1 at 41BP491, looking south. Scale is two meters in length, and is approximately 20 cmbs. meter or so, but extremely loose sediments below. The trench contained cultural materials between 120 and 160 cmbs; excavations were halted at $160 \mathrm{cmbs}$ because of the risk of trench sidewalls collapsing. Artifact finds included pieces of fire-cracked rock and a piece of charcoal from 120 to 130 cmbs. No artifacts or cultural materials were observed in BHT 2, one end of which collapsed at 150 cmbs. The dispersed nature of the FCR did not record firm evidence of intact features. On the basis of these results, this site appears to be a scatter of cultural materials, found at widely ranging depths below surface.

The age of this site is currently unknown. On the basis of artifacts observed during the current phase of research, its original assessment as an open campsite is supported. The previous shovel tests and current backhoe trenches can be used to confirm the original recommendations, and can be used to suggest that the 41BP491 is potentially eligible for listing on the NRHP and additional work is recommended. 


\section{BP528}

Like 41BP491, this site was originally reported by Robinson (2001). This small site is located on a sideslope overlooking the floodplain of a small intermittent drainage that runs approximately $50 \mathrm{~m}$ to the west. Vegetation includes moderately dense stands of oak and juniper, with very little ground cover. Silstid loamy fine sand soils cover the site.

Nickels and Lehman (2004b:70-71) revisited the site in 2002-2003, and describe it as a prehistoric campsite. Robinson and his colleagues excavated eight shovel tests, one of which yielded two flakes, two pieces of burned rock, and an untyped but probably Late Archaic dart point fragment. During the CAS revisit, 15 additional shovel tests were excavated, producing fivepieces of fire-cracked rock (including both large and small pieces), a bullet, and three flakes. Artifacts were recovered from depths that ranged from 10 to 70 cmbs, and Nickels and Lehman (2004b:71-72) suggest that multiple discrete components, including possible hearth features, may be present at the site. Overall depths of the CAS shovel tests varied between 10 and $70 \mathrm{cmbs}$; all shovel tests reached the underlying red clay substratum. On the basis of their shovel tests, Nickels and Lehman (2004b) recommended that three backhoe trenches be excavated at 41BP528 near STs 6, 7, and 13 (Figure 3-55).
CAS excavated three backhoe trenches in 2005. Backhoe trench profiles were described for each and are provided below followed by a photograph of the profile described (Figures 356 to 3-58) In the backhoe trenches, shallow and thin A, E and B horizons without stratigraphic breaks were documented in the upper $36 \mathrm{~cm}$ of BHT 1, $55 \mathrm{~cm}$ of BHT 2, and $60 \mathrm{~cm}$ of BHT 3 . Below these depths are clayey 2Bt horizons representing weathered bedrock deposits.

\section{Description of sediments in BHT 1 (Profile 11) $41 B P 528$}

Zone 1: 0-12 cmbs, pale brown (10YR6/3) loose fine sandy loam, abundant organic decomposing leaf litter, common rootlets, few roots, abrupt wavy lower boundary, A horizon.

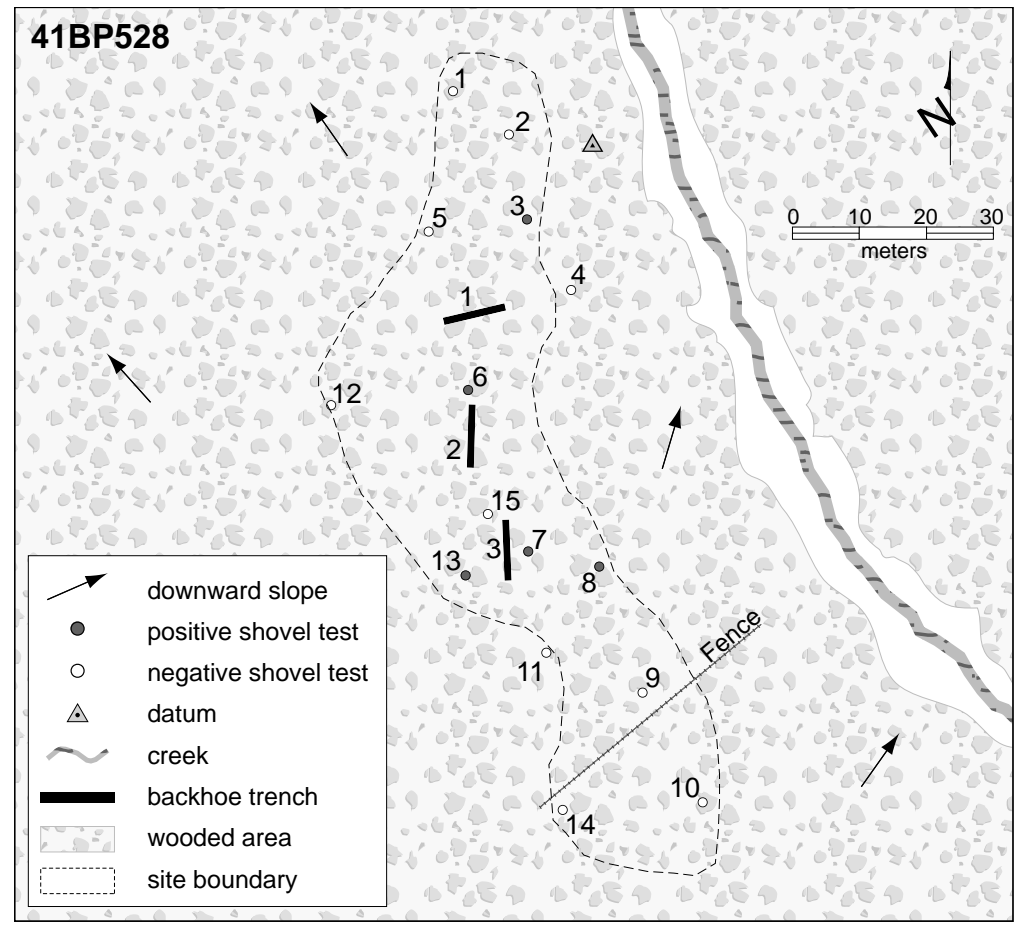

Figure 3-55. Map of 41BP528 showing locations of backhoe trenches and 2002-2003 shovel tests (adapted from Nickels and Lehman 2004b: Figure 4-43). 


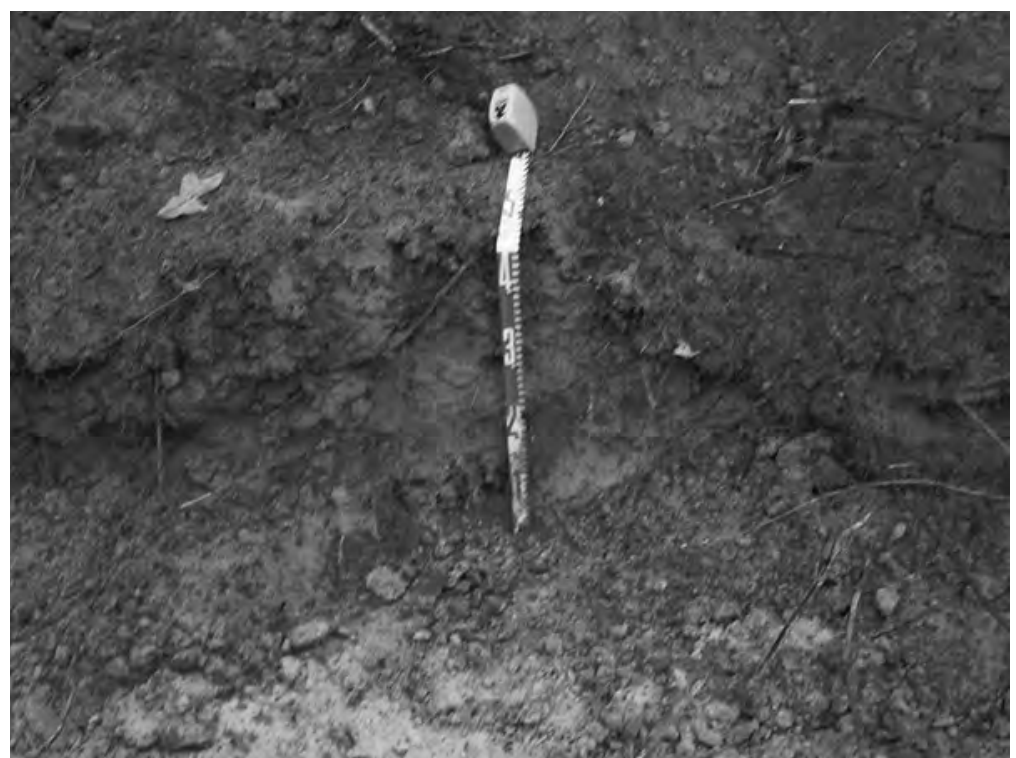

Figure 3-56. Profile 11 in BHT 1 at 41BP528.

Zone 2: 12-36 cmbs, very pale brown (10YR7/3) friable sand, common rootlets and insect burrows, very abrupt irregular lower boundary, E horizon.

Zone 3: 36+ cmbs, reddish brown (2.5YR4/3) sandy clay loam, medium to moderate subangular blocky structure, lower boundary not observed, 2Bt horizon.

\section{Description of sediments in BHT 2 (Profile 12) 41BP528}

Zone 1: 0-5 cmbs, pale brown (10YR6/3) friable sandy loam, twigs and leaves on surface, common rootlets and insect burrows, worm casts, very abrupt to wavy lower boundary, A horizon.

Zone 2: 5-55 cmbs, very pale brown (10YR7/3) friable massive fine sandy loam, common rootlets, few roots, abrupt wavy to smooth lower boundary, B horizon.

Zone 3: 55-75+ cmbs, strong brown to very pale brown (7.5YR5/6 to 10YR7/3) firm sandy clay loam, lower boundary not observed, 2Bt horizon.

\section{Description of sediments in BHT 3 (Profile 13) 41BP528}

Zone 1: 0-19 cmbs, pale brown (10YR6/3) loose sandy loam, common rootlets, few roots, clear smooth lower boundary, A horizon.

Zone 2: 19-60 cmbs, very pale brown (10YR7/3) friable sandy loam, common rootlets, few roots, clear smooth lower boundary, E horizon.

Zone 3: 60-85 cmbs, very pale brown (10YR7/3) firm sandy clay loam, reddish yellow (7.5YR7/6)

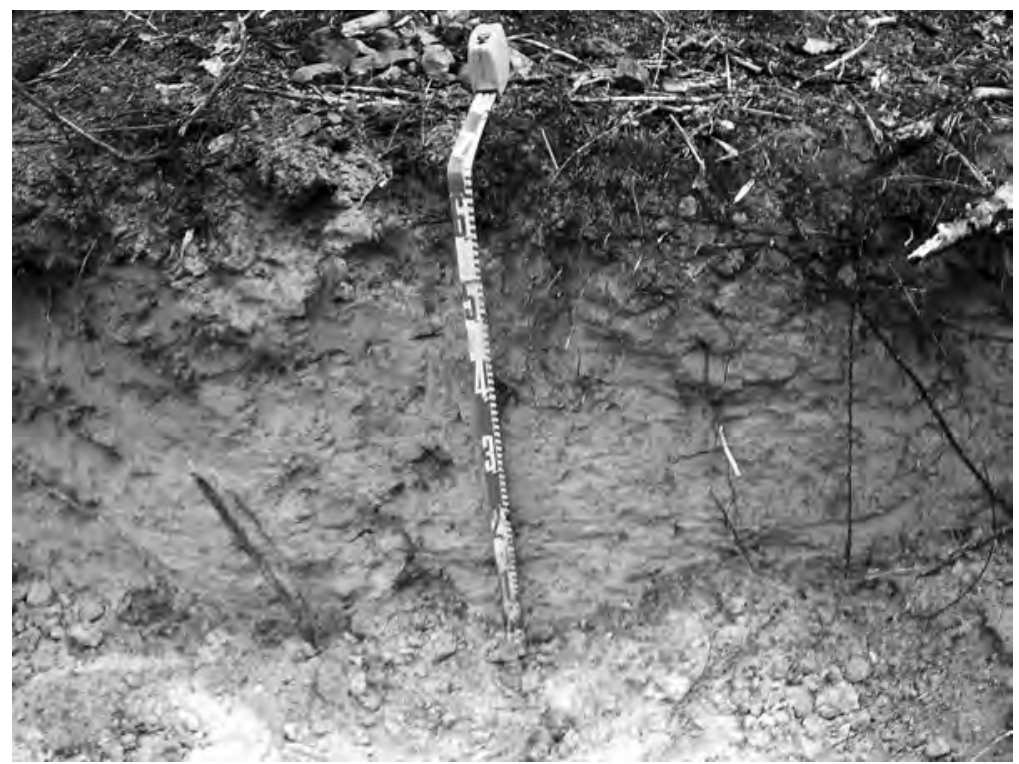

Figure 3-57. Profile 12 in BHT 2 at 41BP528. 


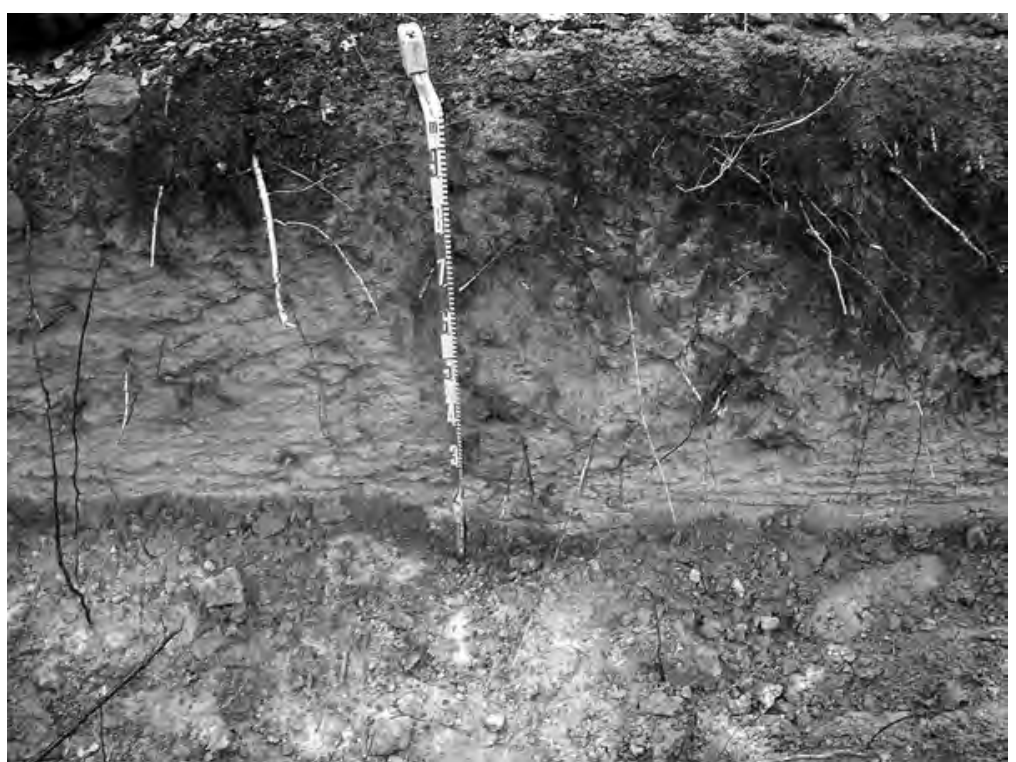

Figure 3-58. Profile 13 in BHT 3 at 41BP528.

faint fine firm mottles, clear smooth lower boundary, 2Bt1 horizon.

Zone 4: $85-105+$ cmbs, very pale brown (10YR7/3) very firm medium sandy clay loam, strong brown (7.5YR4/6) faint to distinct fine to medium mottles, some surrounding ironstone concretions, lower boundary not observed, 2Bt2 horizon.

The three backhoe trenches together revealed the same varied depths of sediments indicated by the earlier shovel tests (Table 3-8). Additionally, cultural remains were variable in their abundance. Backhoe Trench 1 was stopped at approximately $36 \mathrm{cmbs}$, the depth of the underlying red clay substratum. Five pieces of firecracked rock were observed in this trench, ranging in size from $5 \mathrm{~cm}$ to just over $1 \mathrm{~cm}$ in diameter. Backhoe Trench 2, however, showed a somewhat larger amount of fire-cracked rock including over 30 pieces from between 35 and 65 cmbs. At least three small flakes were also observed from this trench, coming from the same depths as the fire-cracked rock. Underlying red clay was reached at approximately 75 cmbs. Backhoe Trench 3 (Figure 3-59) reached a depth of about 105 cmbs, and contained abundant firecracked rock ( $\mathrm{n}=$ at least 15) between 20 and 65 cmbs. Together with the results of earlier efforts at this site, artifact presence in BHTs 2 and 3 indicate the presence of a fairly well defined buried cultural component at the site containing abundant fire-cracked rock, small

Table 3-8. Approximate depths of artifact recovery from backhoe trenches at 41BP528. When no depth could be recorded, artifact depth is listed as "unknown."

\begin{tabular}{|c|c|c|c|c|c|c|}
\hline Trench & $\begin{array}{c}\text { Bottom } \\
\text { Elevation } \\
\text { (cmbs) }\end{array}$ & $\begin{array}{c}\text { Clay } \\
\text { Reached? }\end{array}$ & $\begin{array}{c}\text { Debitage } \\
\text { (cmbs) }\end{array}$ & $\begin{array}{c}\text { Charcoal } \\
\text { (cmbs) }\end{array}$ & $\begin{array}{c}\text { FCR } \\
\text { (cmbs) }\end{array}$ & $\begin{array}{c}\text { Others } \\
\text { (cmbs) }\end{array}$ \\
\hline BHT 1 & 30 & yes & & & unknown & \\
\hline BHT 2 & 75 & yes & $35-65$ & & $35-65$ & \\
\hline BHT 3 & 105 & yes & & & $20-65$ & \\
\hline
\end{tabular}




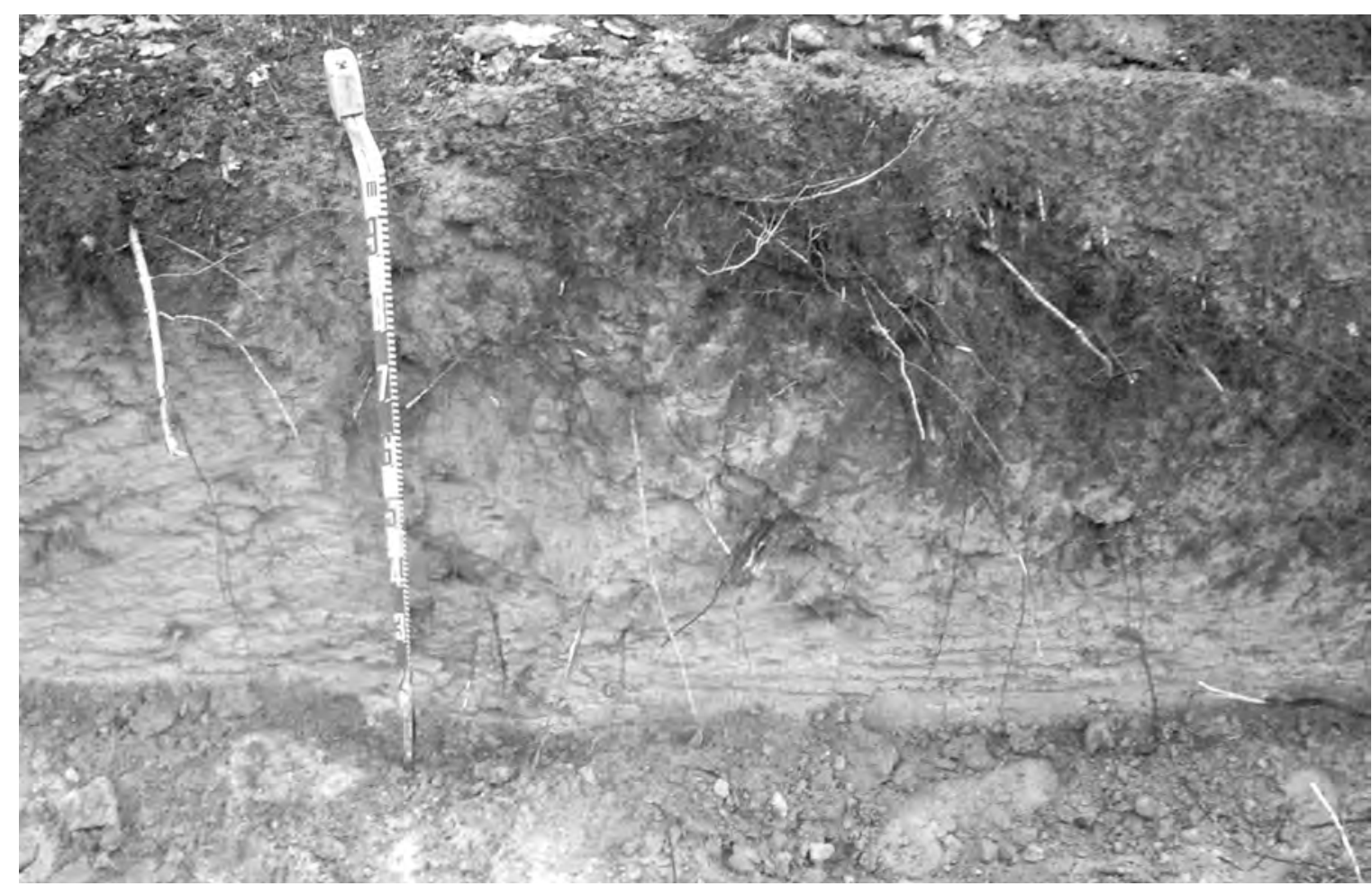

Figure 3-59. South wall profile of BHT 3, showing total sediment depths of just over one meter.

amounts of lithic debris, and even temporally diagnostic lithic artifacts.

Previous investigations suggest a Late Archaic occupation at this site and possibly other ages. On the basis of artifacts observed during the current phase of research, its original assessment as an open campsite is likely. As abundant fire-cracked rock, probably representing features, was observed in association with common prehistoric artifacts, 41BP528 is considered potentially eligible for listing to the NRHP and additional work is recommended. 


\section{Chapter 4}

\section{Conclusions ANd ReseARCH INTERESTS}

The current testing effort contributes to understanding Camp Swift's culture history while also raising issues that apply directly to how sites in this region, characterized by prehistoric artifacts and features distributed in deep sandy sediments, can be approached in a manner that allows the TXARNG to satisfy its current and future Section 106 regulatory compliance obligations. The following discussion of results is framed through two perspectives: 1 ) how the results of these efforts contribute to the larger understanding of Camp Swift culture history, including identifying unanswered questions and further work; and 2) how this and efforts elsewhere in the sandy mantle might be fruitfully approached by archaeologists.

When taken together, these two perspectives address the principal issues formulated by Bousman and Nickels (2004) in the research design developed for this project. Those central problems include:

1) Formation of the Sandy Mantle: understanding the geomorphic processes, rates of sedimentation, and degree of turbation for the overlying sandsheet, as the origins and nature of this heterogeneous deposit condition the potential for intact cultural deposits (see Bruseth and Martin 2001; Frederick and Bateman 2001; Bateman et al. 2003; Bateman et al. in press).
2) Depths of the Sandsheet: evaluating the depths of sandy sediments and relationships of deeply buried artifacts contained therein to the underlying $\mathrm{Bt}$ horizon (the at-leastPleistocene-age paleosol that underlies Holocene-age sediments across the camp). Prochnow (2001) suggested that a sharp unconformity defines the boundary between the overlying sandsheet and underlying $\mathrm{Bt}$ horizon in floodplains and low-lying terraces, and that this abrupt boundary indicates a Holocene scouring event that occurred by at least $600 \mathrm{BP}$. He predicted that older sites, those predating this event, located in these lowland settings could be in secondary context. Primary context sites are possible under this model, though are more likely to occur in upland settings or very deeply buried in lowland settings and would further depend on pedogenic processes (related to the preceding issue).

3) Chronological Occupation of Camp Swift: no Middle Archaic diagnostic artifacts have yet been reported from Camp Swift, and available data reflect very low site frequencies for Paleoindian and Early Archaic times (see following discussion). Consequently, these periods are less well understood (or not understood at all) than Late Archaic and Late Prehistoric periods (see Figure 2-5). 


\section{Understanding the Sandy Mantle}

Currently, two prevailing positions frame how archaeologists understand the sandy mantle and approach the potential research value of sites situated in this broadly ranging landform. These approaches have been summarized by Bruseth and Martin (2001) and Frederick and Bateman (2001) on the basis of work in Lee County (Ricklis 2001; Rogers 1995a), Harrison (Keller 2000), Grimes County (Rogers 1995b), and Freestone and Leon Counties (Fields et al. 1991). These positions revolve around differing, though not completely opposing, views on the capacity of sandy mantle sites to preserve stratigraphically intact sediments and site components. Central issues in this debate include (1) modeling geomorphic processes of sediment build-up and stabilization leading to soil formation (pedogenesis), and understanding rates and effects of post-depositional turbation on sediment columns; (2) dating of deposits by independent means that have included diagnostic artifact typology, radiocarbon, and optically stimulated luminescence (OSL); (3) the central role of OSL dating methods for developing models of the sandy mantle development and pedogenesis; (4) understanding site components that do not exhibit strong horizontal zonation or crisp vertical separation; and (5) extrapolating from site-specific records to regional trends across the sandy mantle.

\section{Optically Stimulated Luminescence Dating}

Much of the current understanding of sandy mantle landforms and sites revolves around our concepts for the origin of sediment sources, the tempo and nature of sediment build-up, and mechanisms for sediment transport, deposition, turbation, and other pedogenic processes. Dating the process of sediment aggradation, in particular, has become a primary issue of contention. Sandy mantle sites often contain little to no organic remains beyond infrequent wood charcoal, and the sediments themselves are very poorly differentiated into soil horizons with visible depositional units. This apparently homogenous character makes them a challenge for traditional geoarchaeological analyses used to reconstruct geomorphic histories in other kinds of landscape settings. Optically stimulated luminescence (OSL) dating, one of a host of luminescence dating techniques, is an ideal tool for dating these landforms and related sites. In opportune situations, OSL can date sediments between 100 and 200,000 years, \pm 10 percent.

OSL provides a determination of the time elapsed since a sediment sample was last exposed to sunlight. Soils contain trace amounts of uranium, thorium, and potassium that decay over time, producing ionizing radiation. This radiation is absorbed by adjacent constituents in the sediments, most particularly quartz and feldspar (Bruseth and Martin 2001). Different minerals store radiation at different rates, referred to as a dose rate, and this can be measured with glow curves. This means that sediments such as the quartz-based sands that cover the current project area are ideally suited for this technique. Stimulating samples collected from the field with infrared light causes luminescent emissions which vary in intensity according to the amount of stored radiation. As ionizing radiation occurs at a set rate under normal circumstances, measuring the intensity of luminescent emissions can give an indication of the time elapsed since the sample began absorbing radiation. The luminescent signature is bleached, or "zeroed out" by prolonged, direct exposure to sunlight; this process is referred to as resetting or "zeroing" the time clock (Frederick et al. 2001:84). 
Because of the effects of sunlight exposure on the "time clock" of feldspar or quartz grains, some mechanisms of sediment transport are better suited for OSL dating than others. In particular, colluvial (gravity impelled movement across and down slopes) and eolian (windblown) sediments with sufficient quartz or feldspar content are more easily dated by OSL. In contrast, alluvial sediments (those deposited by running water) are not as accurately dated by OSL because their exposure to sunlight can be blocked during transport, prior to burial. The dose rate for silica-rich sediments (clay) is not well understood, rendering these sediments poor candidates for OSL dating. OSL has acquired a central role in the sandy mantle debate, as these landforms have been notoriously difficult to decipher by standard geoarchaeological techniques. Exceptions include parts of the state characterized in prehistory by large amounts of burning or other cultural activities that have produced distinctively stained sediments (such as the Caddo region), where some occupation surfaces and horizons can be identified on the basis of sharp discoloration.

Typically, OSL samples have been collected as an aggregate of individual grains. Samples can be collected from along columns in excavation units or backhoe trench sidewalls. Ideally, these samples will yield progressively younger dates from the bottom to the top of the column. Under conditions of turbation or disturbance, however, inversions will occur in which dates are stratigraphically reversed. Bateman et al. (2003) have identified and documented one problem with aggregated OSL samples involving the possibility of including grains transported from elsewhere through vectors of disturbance commonly known as pedoturbation. These out-of-place grains will have a skewing effect on the sample age, potentially rendering inaccurate OSL chronologies for sites. One potential means for overcoming this problem in possibly-disturbed sites is through singlegrain OSL dating (e.g., Bateman et al. 2003, Feathers 2003), which derives an age estimation directly from a single quartz or feldspar grain. While it is possible for individual grains to be vertically displaced within a sediment column, compiling columnar samples of single-grain OSL dates from sites with independent lines of correlating evidence available $\left({ }^{14} \mathrm{C}\right.$, artifact typology, and geomorphic reconstruction) should reveal the relative "intactness" of a deposit. This will allow archaeologists to evaluate the probability that the site's cultural stratigraphy is representative of prehistoric occupation rather than a reconstituted product of downward artifact movement through time (see below).

\section{The Bruseth-Martin (BM) Position}

Noting a lack of correspondence between OSL dates and the distribution of temporally diagnostic artifacts at sites in Lee, Harrison, and other counties, the BM position argues that (1) the sandy mantle formed a long time ago from weathering of underlying Paleocene-Eocene sandstone bedrock, and (2) artifacts have been deposited on land surfaces that have been stable at least since Caddo times (ca. AD 900 onwards) if not much earlier, and these artifacts have gradually worked their way down the sediment column through bioturbation. In cases where Holocene-era soils contain chronologicallyordered Archaic-period deposits, the impression that sediments accumulated at approximately the same rates in which cultural materials were deposited (i.e., in which sites were formed) is false and that the two processes (sediment build-up and deposition of occupation debris) are, in fact, independent. Such stratigraphies were referred to as "reconstituted" by Thoms (1993). Moreover, agents of bioturbation, such 
as the pocket gopher, are concentrated within the upper 1.0-1.5 m, and that upper sediments from this depth range will consistently yield dates that are too young. This claim makes the point that even if landforms and sites aggraded at the same rate, shallowly buried cultural components will be too mixed by rodent and other agents to be considered intact. Buried features found on these sites are argued to be ground surface intrusions since they do not correspond with spikes in distribution of other artifact categories, such as lithic debitage. In the BM position, burned rock clusters are more accurately viewed as the remains of cooking pits that have been opened and cleaned out. The 0.3- to 1.5-m depth at which these features are commonly found across the sandy mantle is described as "the ideal depth for oven-processing of food” (Bruseth and Martin 2001:16), providing an adaptionalist accounting for the regular appearance of features. Supporting "evidence" cited by BM for the "rocks in pits" hypothesis is the lack of any other kinds of features at sandy mantle sites such as post holes, storage pits, burials, and refuse pits.

To summarize, the BM argument includes the following points:

1) The sandy mantle is a non-aggrading landform.

2) These landforms are highly turbated, especially in the upper 1.0-1.5 m.

3) Artifacts found at depth have gradually worked their way down through the sediment column and do not reflect actual occupation episodes.

4) Features between 0.3 and $1.5 \mathrm{~m}$ in depth are most often intrusive from the stable Holocene ground surface; rare deeper features are not seen because they have been obscured by bioturbation.
5) The apparent correlation of independent lines of evidence such as temporally diagnostic artifacts and chronometric dates is due to systematic translocation of all materials down-profile.

\section{The Frederick-Bateman (FB) Position}

After a review of OSL applications in Texas, the FB position offers five fundamental observations on these investigations. First, insufficient cross-checks exist between OSL suites and other independent dating tools, even though studies across the globe have used this technique successfully. Second, OSL results in Texas are difficult to evaluate because samples yield insufficient dates or cannot be verified with other evidence. Third, OSL accuracy is dependent on depositional setting, with good dates coming from colluvial settings and problematic ones from alluvial environments where there is inadequate exposure to sunlight required to "reset the time clock" for quartz sand grains. Fourth, when cross-checks between OSL and ${ }^{14} \mathrm{C}$ are used, they indicate that the OSL dates are either consistent with or older than the ${ }^{14} \mathrm{C}$ dates. Fifth, OSL dating of argillic horizons with heavy clay fractions poses problems due to the different dose rate for clay grains in comparison with quartz sands.

The FB position acknowledges problems with the OSL dating technique at some sandy sites, particularly as the application of this technique to Texas sandy mantle sites is in the process of being perfected. However, those authors review results from one site in particular, 41LE177, that show close correspondence between three independent lines of evidence: internal consistency of OSL dates (of 27 dates in one area of the site, three were in reversed position and only one of these was in Holocene sediments); chronology of geomorphic events, 
marked by periods of Pleistocene gullying, followed by early to mid-Holocene stability, followed by post-mid-Holocene colluviation, that corresponds to a sequence noted in Freestone County (Bousman and Fields 1991); and the artifact sequence, which is marked by only onethird of temporally diagnostic artifacts being out of place. Importantly, all of the artifacts (except historic items) that were found out of place at 41LE177 were recovered from layers dated younger than the artifact types themselves. Contrary to BM, FB argue that this pattern of recovery is expected of colluvial action and does not support a model of pedoturbation, which should result in at least some artifacts being found in older deposits (i.e., both up and down mixing of deposits).

Additional observations by the FB position include issues of scale and understanding for how site-bearing landforms evolve and are affected by disturbance factors. FB contend that not all sandy mantle sites are on non-aggrading landforms and that, instead, this very large region of Texas shows a high degree of variability in terms of ancient and modern gullies and preserved fragments of buried soils. Discerning the specific geomorphic history of a site's particular setting is central to understanding whether it represents an aggrading environment capable of containing stratigraphically discrete deposits or not. Similarly, FB take exception to the BM position that all sandy mantle sites have been bioturbated to the point where any cultural deposits have been hopelessly mixed. Recognizing such disturbances and their extent needs to occur on a site-by-site basis.

A final tenet of the FB position addresses mechanisms for sediment transport and deposition. Sediments in the sandy mantle are commonly argued to have been wind-blown eolian deposits, river-borne alluvial deposits, or in situ weathering of eroding Eocene sandstone bedrock. An important addition to this inventory includes colluvial action. Each mechanism can raise different implications for the applicability of OSL as a dating tool, and also for the relative dynamism or stasis of landforms in question. As with other geomorphic provinces of the state (Blackland Prairies, Edwards Plateau, Llano Uplift, etc.), FB argue that no single model of landform formation fits all scenarios, and that localized processes must be identified before generalized vectors of disturbance or unfavorable depositional history can be invoked to nullify a site's research potential.

To summarize, the FB argument includes the following points:

1) On a site-by-site basis, previous research has shown that as many as three independent variables (OSL, artifact chronology, and geomorphic history) correlate, allowing archaeologists to present fair and accurate descriptions of sediment build-up that cooccurred with site deposition.

2) The OSL dating technique currently seems to work best in colluvial settings, as waterborne sediments are often deprived of adequate exposure to sunlight necessary to "reset the time clock."

3) Landforms across the sandy mantle can be both static and non-aggrading, as BM suggest, and also dynamic and aggrading.

4) Site-by-site assessments, or at most those operating at moderate scales (i.e., watersheds or drainage systems), need to be made regarding the geomorphic makeup and nature of the sandy mantle and its capacity for bearing stratigraphically ordered cultural components. 


\section{Effect of Sandy Mantle Debate on Understanding Camp Swift Sites}

The dialogue between FB and BM holds important implications for how most prehistoric sites at Camp Swift are to be understood. Clearly, how this issue is resolved will impact how individual sites are viewed as potentially eligible for listing to the NRHP. More heavily disturbed deposits or those composed of "reconstituted cultural stratigraphies," in which the apparent association of artifacts is only a result of their downward migration through the sediment column through time, are typically viewed as ineligible for NRHP listing; however, in the future these two processes should be analyzed separately. If sites are shown to be heavily disturbed, then this could be taken to mean that the TXARNG would be freed from federally legislated responsibility for managing, conserving, or otherwise maintaining these properties with respect to Section 106 considerations. In contrast, if sandy mantle sites are determined to reflect gradual build-up of sediments over time and be potentially capable of containing stratified, or at least relatively pristine deposits little disturbed since deposition, NRHP criteria could be more widely applied to sites. Alternatively, if sites can be shown to contain "reconstituted" assemblages, then further debate may be necessary. Regardless of how the sandy mantle debate is resolved, an important exception to this involves the question of chronology of site occupations, addressed below.

In light of the differences between the $\mathrm{BM}$ and $\mathrm{FB}$ positions summarized above, archaeologists working in the sandy mantle must ask, how do we reconcile these positions? CAS suggests applying multiple chronometric approaches to sites containing stratigraphically-ordered deposits. Integrating techniques such as typological dating analysis of artifacts, radiocarbon dating, and OSL can provide meaningful information to our overall understanding of the past. Additionally, more detailed studies that provide information regarding mixing of sediments or artifacts should also be implemented.

\section{Depths of the Sandsheet}

In his geoarchaeological analysis of Camp Swift, Prochnow (2001) presented distinctions between depositional settings on different kinds of landforms. These can be broadly classed as floodplains, low-lying terraces, elevated terraces, ridges, and slopes (see Chapter 2). The key variable for interpreting these sites in light of the BM and FB positions remains the mechanism of sediment transport. Alluvial systems (affecting floodplains and low-lying terraces) arguably produce poorly differentiated deposits, recent deposits, and/ or those not datable by OSL. Eolian transport and in situ weathering of Eocene sandstone bedrock are the sole processes capable of contributing to deep sandy deposits on ridge tops and most uplands. Discerning between these two processes would seem possible by single-grain OSL dating. Eolian deposits that have accumulated over time should reflect well-ordered age sequences (except in cases of disturbance), while weathered bedrock should reflect widely incongruent OSL dates that reveal possible disturbances as well as the lack of exposure to sunlight for lower sediments since Eocene times (which, at 55-34 million years ago, far exceeds the capacity for dating by OSL). It remains to be seen if eolian-deposited sediments can readily be distinguished from heavily turbated Eocene sediments that have been brought to the surface and then buried.

Many landforms across the Camp, however, represent transitional slope settings such as 
sideslopes, footslopes, and elevated terraces. In such settings, combinations of depositional processes are likely. Elevated terraces (T1 in Figure 2-2) are usually deposited by alluvial action in cases where stream channels have dramatically incised and down-cut since the terrace, or where streams reach elevated flood stages due to extreme flood events. Elevated terraces located at the base of adjacent uplands and slopes may also have aggraded in part through colluvial or even eolian processes. Sideslopes and footslopes also tend to consist primarily of colluvium, with the potential for eolian sediments as well. According to the FB position summarized above, the potential for intact sites on sideslopes and footslopes is good, though still requires site-by-site assessments, carried out on a localized scale, to decipher the geomorphic history of individual landforms.

Table 1-1 shows that all of the eight sites addressed in the current testing effort, with the exception of 41BP105, are located on upland settings, ridges, and sideslopes. Depths of sandy sediments range from barely a half-
Table 4-1. List of features recorded in the current effort by site, depth, and site landform.

\begin{tabular}{|c|c|c|c|}
\hline $\begin{array}{c}\text { Site } \\
\text { No. }\end{array}$ & Feature & $\begin{array}{c}\text { Depth } \\
\text { (cmbs) }\end{array}$ & $\begin{array}{c}\text { Site } \\
\text { Landform }\end{array}$ \\
\hline 41BP113 & 1 & ca. 35 & Sideslope \\
\hline 41BP113 & 2 & $85-90$ & Sideslope \\
\hline 41BP113 & 3 & $75-80$ & Sideslope \\
\hline 41BP471 & 1 & ca. 40 & Open sideslope \\
\hline 41BP471 & 2 & $60-65$ & Open sideslope \\
\hline
\end{tabular}

from 41BP491, where artifacts including firecracked rock were reported at $2 \mathrm{~m}$ below the surface (our trench extended at least to $2.4 \mathrm{~m}$ without exposing the underlying Bt; see Table 3-7). Artifacts including both burned chert and fire-cracked rock were consistently noted at $1.3-1.5 \mathrm{~m}$ below the surface in BHT 2 at site 41BP471; basal clay was not reached in this trench after $2.4 \mathrm{~m}$ of excavation. Without diagnostic artifacts or other means of dating these layers, such as ${ }^{14} \mathrm{C}$ or OSL, however, it is simply not possible to address questions of uniform, region-wide landscape formation as is implicated in the BM position.

meter to well over $2 \mathrm{~m}$, with cultural materials recovered from a range of depths. Of the five features recorded during this project, all were reported between 35 and $90 \mathrm{cmbs}$ (Table 4-1).

These figures provide tentative support for the above assessment that lowlying landforms, such as the low terrace at 41BP105, are less likely to contain intact deposits than in colluvial or eolian settings. The deepest exposures of sandy sediments bearing cultural materials were

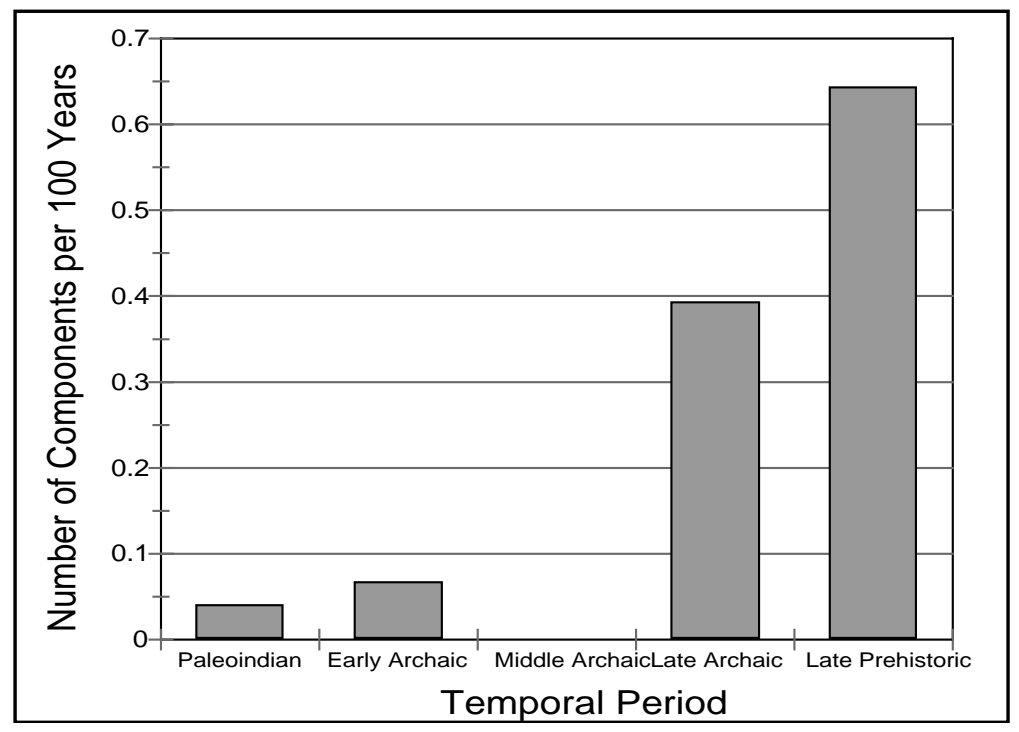

Figure 4-1. Temporal components per 100 years based on diagnostic artifacts recovered so far from Camp Swift (Nickels et al. 2005:6-1). These calculations do not include the Late Archaic Pedernales-like fragment recovered from 41BP113. 


\section{Chronological Occupation of Camp Swift}

While the general overview of regional prehistory is presented in Chapter 2, specific data from previous work at Camp Swift are pertinent to the current effort. Nickels (2005b) compiled previously reported diagnostic time markers from Camp Swift; the following discussions are based largely on those data, supplemented by radiocarbon dating results from a recent testing effort at several prehistoric sites (Nickels in prep). In estimating site components by period, Nickels (2005b:74-76) counted the total number of reported diagnostic artifacts for each period, and divided the estimated length of the temporal periods into which those artifacts are placed (see Figure 4-1). This technique is useful for comparing occupation records by providing a general picture of frequency of occupations. These figures reveal no evidence of Middle Archaic occupations (see Chapter 2, also Nickels 2005b) and only minor occupations for the Paleoindian and Early Archaic. The recovery by Robinson (2001) of an Angostura point provides equivocal temporal evidence, as this type seems to span the interval from late in the Late Paleoindian period to early in the Early Archaic. If this type dated exclusively to the Early Archaic, known Paleoindian presence at Camp Swift would be further diminished.

In trying to understand dated components by period, recent radiocarbon evidence is also helpful in demonstrating occupational trends (Table 4-2, Figure 4-2). These data largely confirm the standardized components-per-100years shown in Figure 4-1, with a concentration of dates in the Late Prehistoric Austin Phase (ca. 1200-800 BP), a couple in the Late Archaic, one dating to the Early Archaic, and none in the Middle Archaic or Paleoindian periods. With 44 diagnostic artifacts recovered from Swift so far (Nickels in prep:Table 6-2), supplemented by the $13{ }^{14} \mathrm{C}$ dates in Figure 4-2, it is unlikely that the absence of known Middle Archaic components is due to sampling. Rather, archaeologists should look instead to cultural or environmental factors to explain this gap in the Camp Swift prehistoric occupation record.

Plotting assays by elevation, however, reveals the complex relationship between sample age and depth (Figure 4-3). While the data in Figure 4-2 reveal concentrated Late Archaic and Late Prehistoric occupations, confirming the data in Figure 4-1, Figure 4-3 reveals the uneven depths from which samples of varying ages can occur. These data illustrate the extreme variability of local landform histories irrespective of whether mixing or depositional models are accepted. In fact, evidence shows variability within a single landform at sites that have multiple dates. At 41BP488, a mild inversion is noted between dates Beta-183899 (740 \pm 40 BP) and Beta-183900 (640 \pm 40 BP), though these samples do slightly overlap at two standard deviations. At 41BP495, Beta-183902 $(640 \pm 40 \mathrm{BP})$ is the lowest sample collected at $120-130 \mathrm{cmbs}$ but yielded the youngest date. Another inversion exists between Beta189904 (1,620 $\pm 40 \mathrm{BP})$, at $80-90 \mathrm{cmbs}$, and Beta-183903 (930 $\pm 40 \mathrm{BP})$, at $110-120$ cmbs. Nickels (personal communication 9 November 2005) notes the lowest sample came from a charcoal mass directly on and cutting into the clay substratum, suggesting an intrusive feature such as a large post.

Considering the other, mild inversions, several interpretations can be drawn. It is possible that individual parts of sites are characterized by different sedimentation processes and rates. Alternatively, the inversions may be evidence of excavated pits into the then-ground surface to install cooking features, or posts that intruded 
Table 4-2. Camp Swift radiocarbon assays (adapted from Nickels in prep:Table 8-1).

\begin{tabular}{|c|c|c|c|c|c|c|}
\hline Site & $\begin{array}{c}\text { Beta } \\
\text { Sample } \\
\text { No. }\end{array}$ & $\begin{array}{c}\text { Material } \\
\text { Dated }\end{array}$ & $\begin{array}{l}\text { Depth } \\
\text { (cmbs) }\end{array}$ & $\delta^{13} \mathrm{C}$ & $\begin{array}{l}\text { Conventional } \\
{ }^{14} \mathrm{C} \text { years BP }\end{array}$ & $\begin{array}{c}\text { Calibrated } \\
\text { Years BP, } \\
\text { Two-Sigma } \\
\text { Range }\end{array}$ \\
\hline 41ВР392 & 183895 & $\begin{array}{c}\text { wood } \\
\text { charcoal }\end{array}$ & 70-80 & $-26.90 / 00$ & $870 \pm 40$ & $910-690$ \\
\hline 41BP485 & 183897 & $\begin{array}{c}\text { wood } \\
\text { charcoal }\end{array}$ & $70-80$ & $-27.30 / 00$ & $490 \pm 40$ & $550-490$ \\
\hline 41BP485 & 183896 & $\begin{array}{c}\text { wood } \\
\text { charcoal }\end{array}$ & 90-100 & $-24.80 / 00$ & $2430 \pm 40$ & $2720-2350$ \\
\hline 41BP488 & 183899 & $\begin{array}{c}\text { wood } \\
\text { charcoal }\end{array}$ & 36 & $-26.80 / 00$ & $740 \pm 40$ & $720-650$ \\
\hline 41BP488 & 183900 & $\begin{array}{c}\text { wood } \\
\text { charcoal }\end{array}$ & 61 & $-26.40 / 00$ & $640 \pm 40$ & $670-540$ \\
\hline 41BP488 & 183901 & $\begin{array}{c}\text { wood } \\
\text { charcoal }\end{array}$ & 80-90 & $-25.50 / 00$ & $910 \pm 40$ & $930-730$ \\
\hline 41BP495 & 183898 & $\begin{array}{c}\text { wood } \\
\text { charcoal }\end{array}$ & $30-35$ & $-25.9 \mathrm{o} / \mathrm{oo}$ & $910 \pm 40$ & $930-730$ \\
\hline 41BP495 & 189904 & $\begin{array}{c}\text { wood } \\
\text { charcoal }\end{array}$ & 80-90 & $-25.90 / 00$ & $1620 \pm 40$ & 1580-1410 \\
\hline 41BP495 & 183903 & $\begin{array}{c}\text { wood } \\
\text { charcoal }\end{array}$ & $110-120$ & $-26.0 \mathrm{o} / \mathrm{oo}$ & $930 \pm 40$ & $930-750$ \\
\hline 41BP495 & 183902 & $\begin{array}{c}\text { wood } \\
\text { charcoal }\end{array}$ & 120-130 & $-26.7 \mathrm{o} / \mathrm{oo}$ & $640 \pm 40$ & $670-540$ \\
\hline 41BP505 & 183904 & $\begin{array}{c}\text { wood } \\
\text { charcoal }\end{array}$ & 80-90 & $-26.60 / 00$ & $1840 \pm 40$ & 1870-1700 \\
\hline 41BP521 & 183905 & nutshell & 67 & $-25.80 / 00$ & $1180 \pm 40$ & 1180-980 \\
\hline 41BР529 & 183906 & $\begin{array}{c}\text { wood } \\
\text { charcoal }\end{array}$ & $110-120$ & $-25.7 \mathrm{o} / \mathrm{oo}$ & $5980 \pm 40$ & $6900-6710$ \\
\hline
\end{tabular}

into lower deposits. Another explanation is the original topography was not perfectly flat and therefore in situ deposits of different ages can be at slightly differing elevations. The landforms visited by prehistoric peoples were almost certainly no more level than they are today, meaning components of different ages do not necessarily directly overlie one another across the expanse of a single site and certainly not between sites. Careful excavations that sample large areas are required to determine which of these processes was taking place, or whether they occurred in some combination.
With respect to the apparent occupation gap in Figures 4-1 and 4-2, the period of time including the Middle Archaic is referred to as the Mid-Holocene, which lasted for over 5,000 years (approximately 8000-2500 BP). This period is characterized in both the pollen and faunal records by increasing aridity (summarized in Collins 1995). The peak of this xeric climate is dated to between 7000 and $4500 \mathrm{BP}$ and is referred to as the Altithermal (Holliday 1989). Although this dry climate was particularly pronounced to the north in the Southern High Plains, the overall increase 


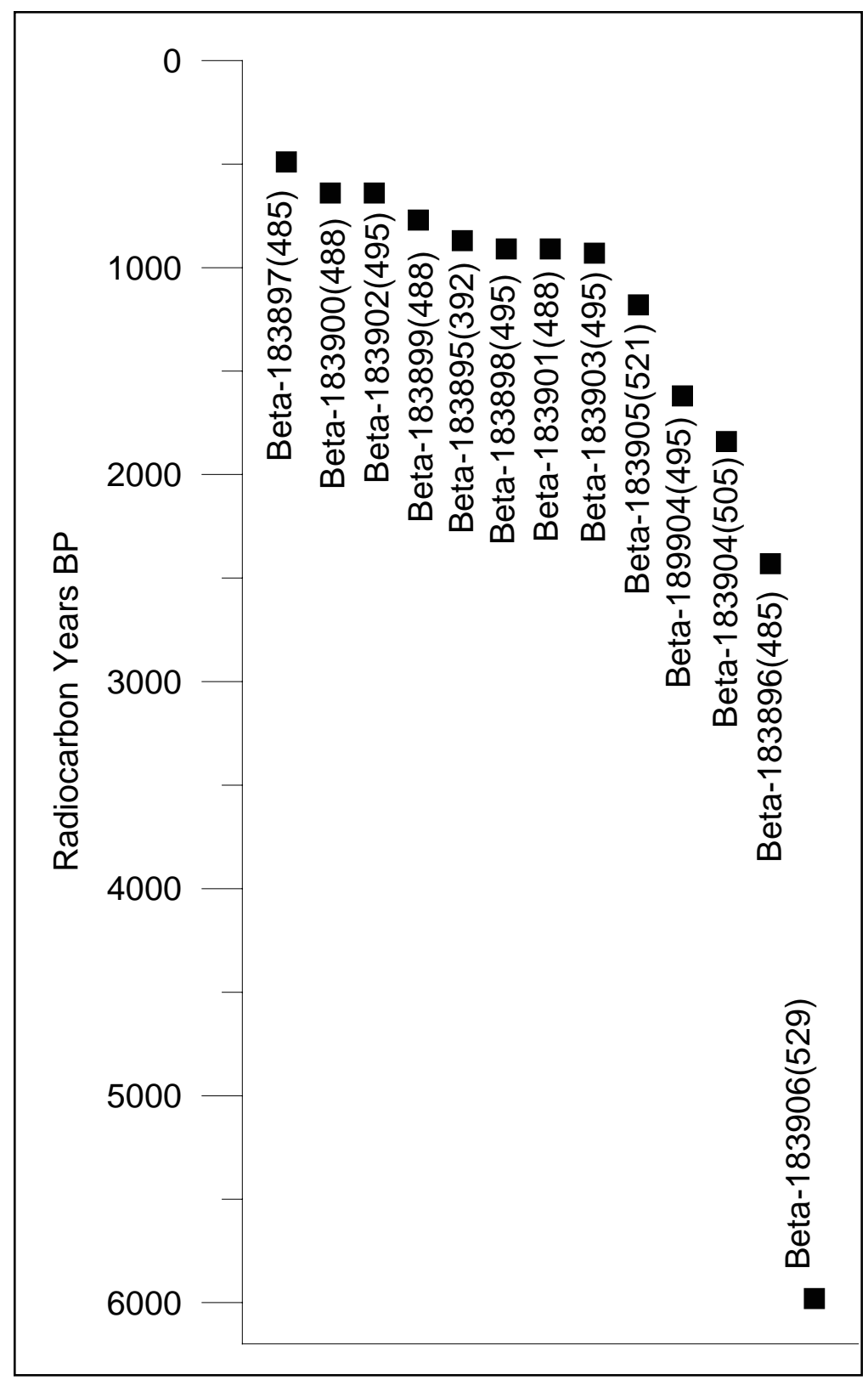

Figure 4-2. Compiled ${ }^{14} \mathrm{C}$ results from Nickels (in prep) from excavated features at Camp Swift, arranged in ascending order by age. Sample numbers listed by corrected ${ }^{14} \mathrm{C}$ dates, site numbers listed in parenthesis.

in mid-Holocene aridity must have certainly played a role in Camp Swift's prehistoric record as well. Today, ground water flow rates across the camp are generally low and sometimes unpredictable. Much of the surface water even disappears in lengthy spells between rainfall events. If dry conditions were prolonged in the past, the general region would have been poorly suited for even seasonal habitation.

The xeric record for the mid-Holocene has additional implications for understanding Middle Archaic (and earlier) occupations at Camp Swift. Prolonged drought conditions have detrimental effects on plant growth and ground cover, making soil loss through erosion and run-off particularly acute. In this scenario, it is possible that much of the sediment record, and any sites contained therein, was either lost from upland settings or deeply buried in lowlands, as regional rainfall and subsequent soil loss increased. This would have been the case until ground cover returned and stabilized landforms.

This scenario appears even more likely given the context in which the handful of Paleoindian and Archaic artifacts from Camp Swift were found. An Angostura point from 41BP485 came from the surface (Robinson 2001:122), and a possible Clovis perform from 41BP495 (Nickels in prep) is associated with a much younger conventional radiocarbon date of $930 \pm 40$ BP. Robinson also recovered a Late Archaic point fragment from 41BP485, suggesting a complex history of artifact deposition and/or sediment movement across this landform. The association between the 


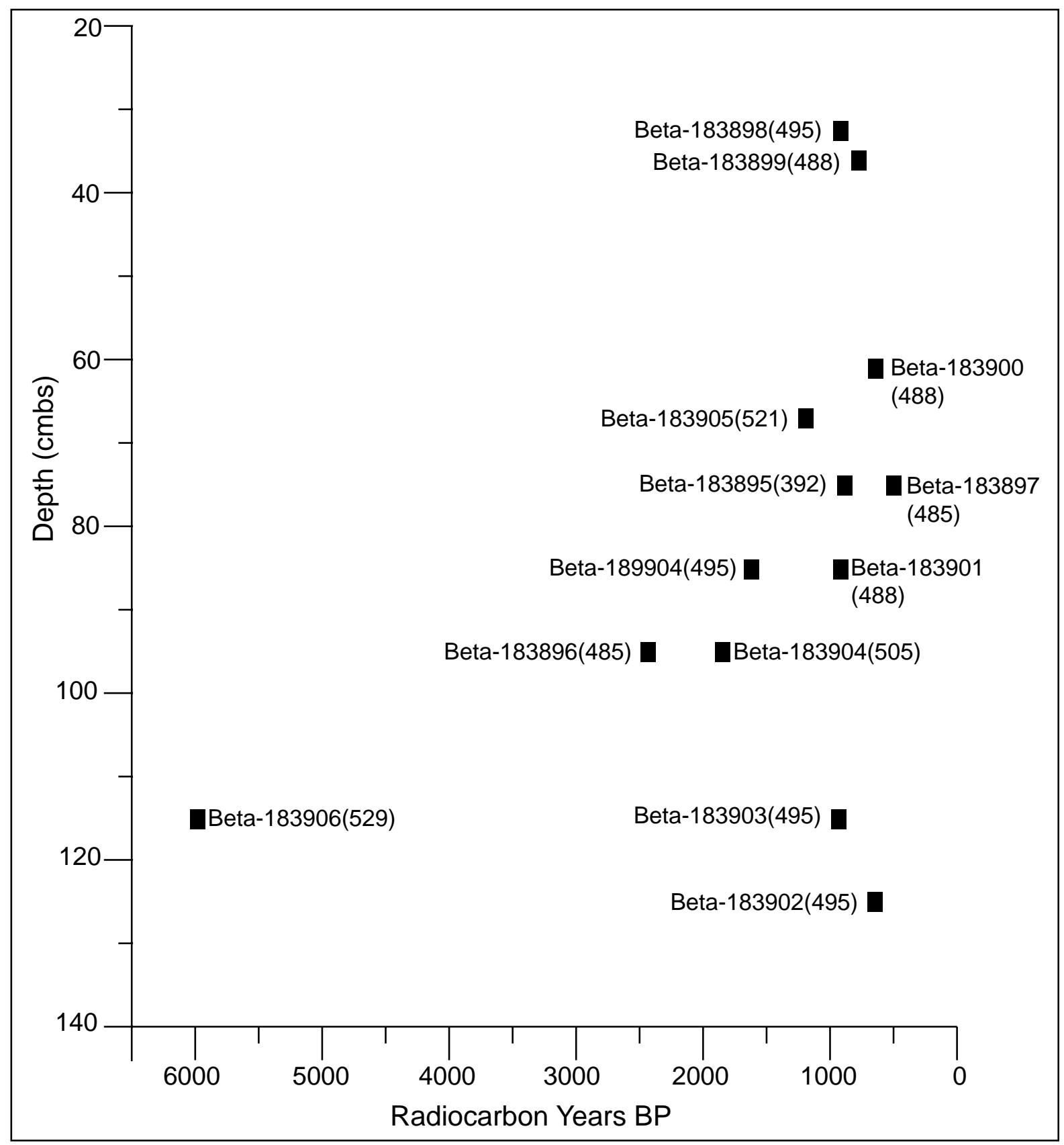

Figure 4-3. Compiled ${ }^{14} \mathrm{C}$ results from Nickels (in prep), arranged by depth of sample below surface to show apparently unpatterned distribution of samples by age. Sample numbers are listed by corrected ${ }^{14} \mathrm{C}$ dates, site numbers listed in parenthesis.

Clovis biface, identified as a preform, and the radiocarbon date poses additional problems for understanding Paleoindian presence across Camp Swift. The other Early Archaic artifact listed in Nickels (in prep:Table 6-2) is an Andice fragment, which is described as a broken but refitting surface find (David Nickels, personal communication 8 November 2005).

The reasoning behind these discussions about dislocated Paleoindian and Early Archaic artifacts is twofold. First, all three 
artifacts are in highly problematical contexts and are not necessarily representative of actual components dating to the Late Pleistocene/ Early Holocene transition. This point provides tentative support for mid-Holocene soil movements and subsequent loss or dislocation of some sites. Second, the fact that all three artifacts were found in contexts too young (on the surface, with a Late Archaic component, and dated by radiocarbon to ca. AD 1000), corresponds with the pattern of artifact recovery described by FB (above) at 41LE177, in which all dislocated diagnostics were found in sediment layers that were too young. This pattern introduces another possible agent for artifact relocation, unconsidered in the BM or FB positions, that perfectly explains some of the displaced diagnostic artifact trends noted in parts of the sandy mantle: people picking up artifacts from elsewhere and bringing them into later occupation sites (a process called artifact re-use). Instances of this behavior have been noted in Spanish mission contexts where Archaic-period stone tools, often patinated from long exposure to sunlight and elements and sometimes reworked, have been recovered from Native American neophyte quarters. Two clear examples include a Guadalupe biface recovered in excavations at the Alamo (Lohse 1999) and a Clear Fork tool from the mission San Bernardo North in Coahuila, Mexico (Inman 1999). These artifacts, typologically dated to several thousand years earlier than the mission contexts in which they were found, easily stood out from their Spanish colonial assemblages. Determining the degree to which older artifacts were picked up and integrated into younger deposits would actually strengthen the FB argument for intact and coherent stratigraphy at sandy mantle sites. Very few, if any, natural processes explain the consistent presence of older artifacts in younger sediments. The impact of people re-using older artifacts onto younger sandy mantle sites could be considered under the FB position by examining traits like patination, reworking, secondary flaking, and patterns of breakage and re-tooling.

The foregoing discussion of dislocated artifacts is not to suggest that no Early Archaic or Paleoindian components exist at Camp Swift. To the contrary, the radiocarbon date Beta-183906 from 41BP529 (5980 \pm 40 BP) clearly indicates early deposits may be found under the right circumstances. However, this review of Camp Swift's prehistoric chronology reveals three important patterns to guide future work:

1) The large majority of diagnostic artifacts and ${ }^{14} \mathrm{C}$-dated features are from the Late Archaic and Late Prehistoric (Austin and Toyah) periods. This can help define possible issues that future work could focus on, such as the nature or seasonality of occupations, and linking Camp Swift components to broader trends elsewhere in Central and Southeastern Texas as part of regional settlement-subsistence patterns.

2) Temporal data are derived from varying depths across the Camp in a way that defies uniform explanations of site and landform formation. Some data are in stratigraphic order while some are not. Moreover, the few Early Archaic and Paleoindian diagnostics that have been found have all occurred in sediments that are younger than the age of the artifacts (or on the surface), suggesting that sources of disturbance such as pocket gophers can not be used to explain their dislocation. Instead, archaeologists should consider other possible explanations such as intrusive pits (following BM) or posts (David Nickels, personal communication 9 November 2005), landscape formation 
variation existing at the site level, narrowly defined and uneven cultural components that do not cover entire site areas, and re-use of older artifacts in more recent contexts. None of these suggested alternatives to the "disturbance vector" theory for artifact dislocation is mutually exclusive of the others.
3) Intact early components (Paleoindian and Early Archaic) are very infrequently encountered, meaning that any future work at Camp Swift should maintain the identification of these as a central priority, regardless of how the sandy mantle debate is eventually resolved. 


\section{Chapter 5}

\section{Recommendations for Site Management AND FUTURE WORK}

Eight sites were examined by CAS archaeologists for intact features to assist the TXARNG in meeting federal compliance requirements for assessing and managing potentially significant cultural resources. These sites, along with three others identified in a previous survey (Nickels and Lehman 2004a), were selected on the basis of artifacts recovered from shovel tests. Future work should focus on the primary issues set forth by Bousman and Nickels (2004) and summarized in Chapter 4 of this report: understanding the formation of the sandy mantle in terms of sediment accumulation and turbation, examining relationships between sand thicknesses and the vertical distribution of artifacts, and resolving the chronology of prehistoric occupations across the camp.

Of the eight sites included in the current testing effort, possible intact features were recorded at five sites: 41BP111, 41BP113, 41BP121 (Area B), 41BP471 and 41BP528, and with multiple features at 41BP113. A sixth site, 41BP491, produced artifacts in deep sands that may be the result of deposition. Artifacts recovered from BHT 1 at 41BP111, including chipping debris and a flaked cobble, were located at approximately the same absolute elevation as Feature 1 observed near the trench, suggesting a possibly intact cultural component is located at this part of the site. The three features from 41BP113 reflect moderately extensive site use. One of these fire-cracked rock features, Feature 3 , was also associated with the basal fragment of a Late Archaic dart point. Dates for all three features remain to be determined, though the dart point fragment provides a tentative age estimate for Feature 3. Artifact recovery from BHTs 4 and 5 at 41BP113, consistently noted at $80-90 \mathrm{~cm}$ below the surface, indicates yet another component at the south end of the site. At 41BP121, the density of fire-cracked rock in BHTs 1 and 2 and the greater density of lithic artifacts between 70-90 cm in BHT 1 suggest the possibility of intact occupations. One feature was recorded at 41BP471 in BHT 5. Additionally, isolable components are indicated by artifact recovery patterns from BHTs 1, 2, and 4. BHT 2 at 41BP471 possibly contains two components, at $50-80 \mathrm{~cm}$ and 130-150 cm, separated by approximately 50 $\mathrm{cm}$, while BHT 4 appears to contain a single component consisting of fire-cracked rocks and debitage. At 41BP528, a possible burned rock feature with associated lithic artifacts that was found in BHT 2 between 35-65 cm, along with another possible fire-cracked rock feature in BHT 3, suggest that this Late Archaic site may have intact occupations.

Based on these results, no further work is recommendedat41BP105 or 41BP118. Additional work is warranted for sites 41BP111, 41BP113, 41BP121, 41BP471, 41BP491, and 41BP528. These sites are in addition to sites 41BP94, 41BP100, and 41BP477 that were initially recommended for additional work based on the results of the 2002-2003 CAS survey (Nickels 
2004b:Table 6-3). It is believed that these sites will yield chronometric information about the nature and range of prehistoric occupations at Camp Swift. At present, in the absence of consensus about the geomorphic history of sandy mantle landforms, chronology remains the predominate issue that should be addressed. Additional lines of inquiry can also be posed, such as subsistence practices or regional distributions of artifact styles or raw material types that indicate boundaries of social groups. Without a firm chronological framework in place, however, it is felt that such questions should be considered secondary in importance in helping archaeologists understand the culture history of Camp Swift.

CAS archaeologists are of the opinion that sites 41BP105 and 41BP118 also could potentially provide information important to understanding prehistoric events and occupations at Camp Swift. However, until the issue of whether sandy mantle sites are seen as capable of containing stratigraphically intact and well-ordered deposits is resolved, no framework is currently available for understanding sites such as these that lack intact features or otherwise diagnostic artifacts and deposits. Therefore, at the current time they are considered not eligible for listing to the NRHP.

Because of our lack of understanding of landform and soil formation processes at Camp Swift and in the sandy mantle, all future excavations should be carried out under a strongly developed geoarchaeological framework focused on refining our understanding of site formation processes and artifact context. Understanding the distribution and condition (intactness) of artifacts and associated features should be grounded in site-specific geologic histories of the landform in which each site is found. Therefore, the placement and recording of excavation units should be designed to recover both archaeological (provenience, context, association) information as well as geological (sedimentation, pedoenesis, turbation) information. Below, we reiterate Nickels' recommended procedures for testing all 11 originally proposed sites.

\section{Recommended Levels of Effort}

Recommendations are provided below for the eight sites plus the three others for which additional work was originally suggested (Table 5-1).

\section{Excavations}

Nickels' original (2003b) recommendations regarding types of analytical techniques are supported and reiterated for all sites. These recommendations include manual excavations of $1 x 1-m$ units carefully controlled in $10-\mathrm{cm}$ levels. All excavated sediments should be screened through $1 / 4$ " mesh for artifact recovery. For 41BP111, 41BP113, 41BP121, 41BP471, 41BP491, and 41BP528, units should be placed adjacent to features or shovel tests recorded in the current or past efforts in an attempt to identify and sample associated artifact refuse. Units should be excavated as far below the depths of recorded features as is feasible so the recovered features and artifacts can be placed into a more comprehensive geological context. When features are encountered, they should be exposed as fully as possible, plan mapped and photographed, and then cross-sectioned in excavation to record vertical depths and any organic or artifact contents. After each unit is completed, profiles should be carefully documented to record the geomorphic evidence regarding sediment build-up and postdepositional processes of stabilization and/or disturbance. Photographs should be taken of all excavations while in progress and upon completion of each unit. Each feature should 
Table 5-1. Recommendations for sites assessed at Camp Swift.

\begin{tabular}{|c|c|c|c|c|}
\hline Site & Type & $\begin{array}{c}\text { Maximum } \\
\text { Depth of } \\
\text { Cultural } \\
\text { Material }\end{array}$ & $\begin{array}{c}\text { Site Size } \\
\left.\mathbf{( m}^{2}\right)\end{array}$ & $\begin{array}{c}\text { No. of } \\
\mathbf{1 x 1 - m} \\
\text { Excavation } \\
\text { Units }\end{array}$ \\
\hline $41 \mathrm{BP} 105$ & $\begin{array}{c}\text { Open } \\
\text { Campsite }\end{array}$ & $110 \mathrm{cmbs}$ & 3,845 & - \\
\hline $41 \mathrm{BP} 111$ & $\begin{array}{c}\text { Open } \\
\text { Campsite }\end{array}$ & $100 \mathrm{cmbs}$ & 23,049 & 5 \\
\hline $41 \mathrm{BP} 113$ & $\begin{array}{c}\text { Open } \\
\text { Campsite }\end{array}$ & $110 \mathrm{cmbs}$ & 20,500 & 7 \\
\hline $41 \mathrm{BP} 118$ & $\begin{array}{c}\text { Open } \\
\text { Campsite }\end{array}$ & $120 \mathrm{cmbs}$ & 1,095 & - \\
\hline $41 \mathrm{BP} 121$ & $\begin{array}{c}\text { Open } \\
\text { Area B }\end{array}$ & $110 \mathrm{cmbs}$ & 8,169 & 5 \\
\hline $41 \mathrm{BP} 471$ & $\begin{array}{c}\text { Open } \\
\text { Campsite }\end{array}$ & $130 \mathrm{cmbs}$ & 25,693 & 9 \\
\hline $41 \mathrm{BP} 491$ & $\begin{array}{c}\text { Open } \\
\text { Campsite }\end{array}$ & $100 \mathrm{cmbs}$ & 4,382 & 3 \\
\hline $41 \mathrm{BP} 528$ & $\begin{array}{c}\text { Open } \\
\text { Campsite }\end{array}$ & $60 \mathrm{cmbs}$ & 2,400 & 3 \\
\hline
\end{tabular}

be extensively photographically recorded in the field as it is excavated.

The recommendations for the inspected sites are summarized in Table 5-1. At 41BP111, STs 29, 32, 34, 37, and 38, and BHTs 1-3 produced lithic artifacts and fire-cracked rock. Based on these results it is recommended that five 1x1-m units be placed near the shovel tests and backhoe trenches to document the potential for intact occupations and the vertical distribution of artifacts. At 41BP113, artifacts and fire-cracked rock were recovered in ST $5,6,9,13,14,15$, and 17, and in BHTs 1-4. These results can be used to recommend that seven 1x1-m units should be excavated by hand at 41BP113, adjacent to positive shovel tests and backhoe trenches. In Area B at 41BP121, artifacts and fire-cracked rock were recovered from STs 22, 23, 24, 26, and 30, and from BHTs 1-4. These results demonstrate five possible locations adjacent to shovel tests that should be tested with 1x1-m hand-excavated units. At 41BP471, STs 1, 4, 5, 7, 8, 14, 15, 16 , and 26 and BHTs $1-5$ yielded artifacts and fire-cracked rock. Nine hand-excavated 1x1$\mathrm{m}$ units are recommended to assess the locations at 41BP471. At 41BP491, three areas should be tested by $1 \times 1-$ $\mathrm{m}$ units. These are the areas near STs 6-7 and BHT 3, STs 11-21 and BT 1, and near ST 18.The final site recommended for hand-excavated 1x1-m test units is 41BP528. STs 6, 7, and 13 and BHTs 1-3 produced artifacts and fire-cracked rock. Three units are recommended at $41 \mathrm{BP} 528$ near the positive shovel tests and especially near BHT 2.

\section{Chronometric Dating}

Archaeologists will recover any burned carbon or faunal remains encountered during excavation. Upon completion of all excavations, samples suitable for AMS radiocarbon dating should be selected on the basis of geologic context, association with features and other cultural components, probability of disturbances, and other factors. Based on a geological assessment of sediments in each unit, samples should be collected for single-grain OSL dating. Bateman et al. (2003) and Bateman et al. (in press) have demonstrated the ability to use single grain OSL dating to assess the degree of pedoturbation in the sandy mantle. At each site, at least one column of dense, continuous, overlapping OSL samples should be collected from a single wall of an excavation unit. These samples will be processed in conjunction with 
additional available dating techniques $\left({ }^{14} \mathrm{C}\right)$ which will provide a means of independently verifying the OSL results. Furthermore, the OSL samples should be assayed as single-grain determinations in order to assess the degree of sediment mixing/turbation. The resulting age sequences should help archaeologists to model processes and timing of sandy mantle landform development, and the context of sites located in these settings.

\section{Additional Sampling}

In addition to the sampling strateges outlined above, magnetic susceptibility (MS) readings should be taken from all excavation units upon their completion. These measurements should be taken at 10cm intervals from the same unit wall as OSL samples. MS readings should be taken adjacent to OSL samples. In this way, MS readings should help archaeologists recognize and identify site components and possible living surfaces. Additionally, MS data will provide a third line of evidence (along with OSL and ${ }^{14} \mathrm{C}$ ) in helping to reconstruct individual site histories.

\section{Artifact Analysis}

Future artifact analysis should focus on the possible affects of turbation on the vertical distribution of artifacts. Mixing models can be used to estimate the rate and pattern of artifact displacement recovered in 1x1-m excavation units. These models can be refined with additional evidence derived from the evidence of possible turbation from OSL samples. The mixing models can be used to help determine when constant turbation may or may not be responsible for the unique patterns in the vertical distribution of historic and prehistoric artifacts.

\section{Future Site Management Recommendations}

If, after additional excavation, these five sites are found to contain intact datable components, further work may be warranted depending on the TXARNG's plans for land use and site treatment. Ideally, if no plans for future activities will impact site areas, they should simply be avoided and left in their current state. Alternatively, if training activities or construction will be conducted in the future that will potentially damage or destroy the sites and their material contents, more intensive data recovery measures should be considered and implemented. The scope of this work will necessarily depend on projected site impact. Minimally, however, excavations should be carried out in a highly controlled manner that addresses both chronological and geological/landform questions (as outlined in earlier sections of the current report). If the sandy mantle issue is resolved and a general understanding reached that at least some sites can be shown to contain intact, ordered deposits even in the absence of features or diagnostic elements, then it is recommended that additional lines of inquiry be developed to explore possible issues of potential significance. While the substance of these issues is yet to be determined, they should minimally attempt to link the archaeological record of Camp Swift with broader regional models of prehistoric occupations in Texas.

Because of the soft nature of the sandy overburden, it is important that these site areas be avoided by heavy vehicle traffic until they can be tested in the next phase of research. It is felt that heavy vehicles could damage or even destroy shallowly buried cultural features and their associated site components. 


\section{References Cited}

Arnn, John

2005 Chronology, Technology, and Subsistence: Is That All There Is? CTA Newsletter 29(2):17-28.

Barker, Frank E.

1979 Soil Survey of Bastrop County, Texas. U. S. Department of Agriculture, Soil Conservation Service, Washington, D.C.

Barnes, Virgil E.

1974 Austin Sheet. In Geologic Atlas of Texas. Bureau of Economic Geology, The University of Texas at Austin.

Bateman, Mark D., C. H. Boulter, A. S. Carr, Charles D. Frederick, D. Peter, and M. Wilder In press Preserving the paleoenvironmental record in drylands? Sedimentary Geology.

Bateman, Mark D., Charles D. Frederick, Manoj K. Jaiswal, and Ashok K. Singhvi

2003 Investigations in the potential effects of pedoturbation on luminescence dating. Quaternary Science Reviews 22:1169-1176.

Black, Stephen L.

1989a Central Texas Plateau Prairie. In From the Gulf Coast to the Rio Grande: Human Adaptation in the Central, South, and Lower Pecos Texas, edited by Thomas R. Hester, Stephen L. Black, D. Gentry Steele, Ben W. Olive, Anne A. Fox, Karl J. Reinhard, and Leland C. Bement, pp. 17-38. Research Series No. 33. Arkansas Archeological Survey, Fayetteville.

1989b Environmental Setting. In From the Gulf Coast to the Rio Grande: Human Adaptation in the Central, South, and Lowe Pecos, Texas, edited by Thomas R. Hester, Stephen L. Black, D. Gentry Steele, Ben W. Olive, Anne A. Fox, Karl J. Reinhard, and Leland C. Bement, pp. 5-17. Research Series No. 33. Arkansas Archeological Survey, Fayetteville.

Black, Stephen L., and Darrell G. Creel

1997 The Central Texas Burned Rock Midden Reconsidered. In Hot Rock Cooking on the Greater Edwards Plateau: Four Burned Rock Midden Sites in West Central Texas, by Stephen L. Black, Linda W. Ellis, Darrell G. Creel, and Glenn T. Goode, pp. 269-306. Studies in Archeology 22, Texas Archeological Research Laboratory, The University of Texas at Austin; and Archeology Studies Program, Report 2, Texas Department of Transportation Environmental Affairs Division, Austin. 
Black, Stephen L., Linda W. Ellis, Darrell G. Creel, and Glenn T. Goode

1997 Hot Rock Cooking on the Greater Edwards Plateau: Four Burned Rock Midden Sites in West Central Texas. Studies in Archeology 22, Texas Archeological Research Laboratory, The University of Texas at Austin; and Archeology Studies Program, Report 2, Texas Department of Transportation Environmental Affairs Division, Austin.

Black, Stephen L., and Al J. McGraw

1985 The Panther Springs Creek Site: Cultural Change and Continuity in the Upper Salado Creek Drainage, South-Central Texas. Archaeological Survey Report No. 100. Center for Archaeological Research, The University of Texas at San Antonio.

Blair, W. Frank

1950 The Biotic Provinces of Texas. Texas Journal of Science 2(1):93-117.

Bousman, C. Britt

1998 Paleoenvironmental Change in Central Texas: The Palynological Evidence. Plains Anthropologist 43:201-219.

Bousman, C. Britt, Barry W. Baker, and Anne C. Kerr

2004 Paleoindian Archeology in Texas. In The Prehistory of Texas, edited by Timothy K. Perttula, pp. 15-97. Texas A\&M Press, College Station.

Bousman, C. Britt, Michael B. Collins, Paul Goldberg, Thomas Stafford, Jan Guy, Barry W. Baker, D. Gentry Steele, Marvin Kay, Anne Kerr, Glen Fredlund, Phil Dering, Vance Holliday, Diane Wilson, Wulf Gose, Susan Dial, Paul Takac, Robin Balinsky, Marilyn Masson, and Joseph F. Powell 2002 The Paleoindian-Archaic Transition in North America: New Evidence from Texas. Antiquity 76:980-990.

Bousman, C. Britt, and Ross C. Fields

1988 Results of the Geoarcheological Investigations. In Archeological Survey of the 1989-1993 Permit Area, Jewitt Mine Project, Freestone and Leon Counties, Texas, edited by Ross C. Fields, pp. 195-237. Reports of Investigations No. 63. Prewitt and Associates, Inc., Austin.

1991 Environmental Setting. In Excavations at the Bottoms, Rena Branch, and Moccasin Springs Site, Jewett Mine Project, Freestone and Leon Counties, Texas., by Ross C. Fields, L. Wayne Klement, C. Britt Bousman, Steve A. Tomka, Eloise F. Gadus, and Margaret A. Howard, pp. 5-20. Reports of Investigations No. 82. Prewitt and Associates, Inc., Austin.

Bousman, C. Britt, and David L. Nickels

2004 Proposal for Supplemental Archaeological Assessments of Eight Category 6 Sites on Camp Swift Training Center near Bastrop, Texas. Unpublished proposal submitted to the Texas Army National Guard Adjutant General’s Office, Austin. 
Bruseth, James E., and William A. Martin

2001 OSL Dating and Sandy Mantle Sites in East Texas. Current Archeology in Texas 3(1):12-17. Texas Historical Commission, Austin.

Byrd, Clifford L.

1971 Origin and History of the Uvalde Gravel of Central Texas. Baylor Geological Studies Bulletin No. 20. Baylor University Press, Waco.

Collins, Michael B.

1995 Forty Years of Archeology in Central Texas. Bulletin of the Texas Archeological Society 66:361-400.

2004 Archeology in Central Texas. In The Prehistory of Texas, edited by Timothy K. Perttula, pp. 101-126. Texas A\&M Press, College Station.

Collins, Michael B. (assembler and editor)

1998 Wilson-Leonard: An 11,000-Year Archeological Record in Central Texas, Volumes 1-6. Studies in Archeology 31, Texas Archeological Research Laboratory, The University of Texas at Austin; and Archeology Studies Program Report 10, Texas Department of Transportation, Environmental Affairs Division, Austin.

Dillehay, Thomas D.

1974 Late Quaternary Bison Population Changes on the Southern Plains. Plains Anthropologist 19(64):180-196.

Doran, Glenn H. (editor)

2002 Windover: Multidisciplinary Investigations of an Early Archaic Florida Cemetery. University of Florida Press, Gainesville.

Feathers, James K.

2003 Single-grain OSL dating of sediments from the Southern High Plains, USA. Quaternary Science Reviews 22:1035-1042.

Fields, Ross C.

1995 The Archeology of the Post Oak Savannah of East Central Texas. Bulletin of the Texas Archeological Society 66:310-330.

Fields, Ross C., L. Wayne Klement, C. Britt Bousman, Steve A. Tomka, Eloise F. Gadus, and Margaret A. Howard

1991 Excavations at the Bottoms, Rena Branch, and Moccasin Springs Site, Jewett Mine Project, Freestone and Leon Counties, Texas. Report of Investigations No. 82. Prewitt and Associates, Inc., Austin. 
Frederick, Charles D., and Mark D. Bateman

2001 OSL Dating and Sandy-Mantle Sites in East Texas: A Reply. Current Archeology in Texas 3(2):14-18.

Frederick, Charles D., Mark D. Bateman, and Paul Lehman

2001 Geoarchaeological Investigations. In National Register Eligibility Testing at 41LE177, Alcoa Sandow Mine, Lee County, Texas: Archaeological, Geological, and Paleoenvironmental Assessment of an Upland Sandy Mantle Site, edited by Robert A. Ricklis, pp. 83-123. Coastal Archaeological Research, Inc., Corpus Christi.

Goode, Glenn T.

1989 Appendix II. Archaeological Testing and Recommendations for the Kennedy Bluffs Site, 41BP19, in Bastrop County. In Excavations at 41BP19, the Kennedy Bluffs Site, Bastrop Country, Texas, by Leland C. Bement, pp. 155-180. Contract Reports in Archaeology No. 5. Texas State Department of Highways and Public Transportation, Highway Design Division, Austin.

Gould, Frank W.

1975 Texas Plants-A Checklist and Ecological Summary. Revised ed. Bulletin MP-585:5-14. Texas Agricultural Experimentation Station, College Station.

Hall, Grant D.

1981 Allens Creek: A Study in the Cultural Prehistory of the Brazos River Valley, Texas. Research Report No. 61. Texas Archeological Survey, The University of Texas at Austin.

Hester, Thomas R.

2004 The Prehistory of South Texas. In The Prehistory of Texas, edited by Timothy K. Perttula, pp. 121-151. Texas A\&M Press, College Station.

Holliday, Vance T.

1989 Middle Holocene Drought on the Southern High Plains. Quaternary Research 31:74-82.

Houk, Brett A., and Jon C. Lohse

1993 Archeological Investigations at the Mingo Site, Bandera County, Texas. Bulletin of the Texas Archeological Society 61:193-247.

Huebner, Jeffery A.

1991 Late Prehistoric Bison Populations in Central and Southern Texas. Plains Anthropologist 36(137):343-358.

Inman, Betty J.

1999 The Lithic Artifacts of the Native Americans a the Spanish Colonial Missions at Guerrero, Coahuila, Mexico. Bulletin of the Texas Archeological Society 70:363-384. 
Jelks, Edward B.

1962 The Kyle Site: A Stratified Central Texas Aspect Site in the Hill Country, Texas. Archaeology Series No. 5. Department of Anthropology, The University of Texas at Austin.

Johnson, LeRoy

1994 The Life and Times of Toyah-Culture Folk as Seen from the Buckhollow Encampment, Site 41KM16 of Kimble County, Texas. Office of the State Archeologist Report No. 38. Texas Department of Transportation and the Texas Historical Commission, Austin.

Johnson, LeRoy, and Glenn T. Goode

1994 A New Try at Dating and Characterizing Holocene Climates, as well as Archaeological Periods, on the Eastern Edwards Plateau. Bulletin of the Texas Archeological Society 65:1-51.

Johnson, LeRoy, Dee Ann Suhm, and Curtis D. Tunnel

1962 Salvage Archeology of Canyon Reservoir: The Wunderlich, Footbridge, and Oblate Sites. Bulletin of the Texas Memorial Museum No. 5. Texas Memorial Museum, Austin.

Keller, John E.

2000 Archaeological Investigations at 41HS599 and 41HS606, Harrison County, Texas. Report of Investigations 3-2000. Southern Texas Archaeological Consultants, Los Fresnos.

Kelly, J. Charles

1947a The Lehmann Rockshelter: A Stratified Site of the Toyah, Uvalde, and Round Rock Foci. Bulletin of the Texas Archeological and Paleontological Society 18:115-128.

1947b The Cultural Affiliations and Chronological Position of the Clear Fork Focus. American Antiquity 13(2):97-108.

Leffler, John J.

2001 The History of the Camp Swift Area, 1830-1950. In An Archaeological Inventory of Camp Swift, Bastrop County, Texas, edited by Barbara A. Meissner, pp. 14-30. Archaeological Survey Report No. 316. Center for Archaeological Research, The University of Texas at San Antonio.

Lehman, Melissa L., David L. Nickels, and Antonio Padilla

2003 Site Descriptions, Analysis, and Recommendations. In Archaeological Evaluation of 39 Category V Sites at Camp Swift, Bastrop County, Texas: 2001, by David L. Nickels, Melissa L. Lehman, and C. Britt Bousman, pp. 25-132. Archaeological Studies Report No. 3. Center for Archaeological Studies, Southwest Texas State University, San Marcos.

Lohse, Jon C.

1999 Lithics from the San Antonio de Valero Mission: Analysis of Materials from the 1979 Excavations of the Alamo. Bulletin of the Texas Archeological Society 70:265-279. 
Marks, Paula Mitchell

2001 Bastrop Country. Handbook of Texas Online. Electronic document, http:// www.tsha.utexas. edu/ handbook /online/articles/BB/hcb3.html, accessed 28 September, 2005.

Meissner, Barbara A.

1991 Notes on the Excavation of 41BX952. Manuscript on file. Center for Archaeological Research, The University of Texas at San Antonio.

Mesisner, Barbara A. (editor)

1991 An Archaeological Inventory of Camp Swift, Bastrop County, Texas. Archaeological Survey Report No. 316. Center for Archaeological Research, The University of Texas at San Antonio.

Nash, Michael A., Rick F. Taylor, and Elizabeth A. Skokan

1995 A Cultural Resources Survey of the McNeil-Bastrop 138-Kv Transmission Line Rebuild Project, Bastrop and Travis Counties, Texas. Espey, Huston, and Associates, Austin.

Nickels, David L.

2003a Regional and Local Environmental Resources. In Archaeological Evaluation of 39 Category V Sites at Camp Swift, Bastrop County, Texas: 2001, by David L. Nickels, Melissa L. Lehman, and C. Britt Bousman, pp. 3-10. Archaeological Studies Report No. 3. Center for Archaeological Studies, Southwest Texas State University, San Marcos.

2003b Proposal for Supplemental Archaeological Assessments of Eleven Category 6 Sites on Camp Swift Training Center near Bastrop, Texas. Unpublished proposal submitted to the Texas Army National Guard Adjutant General's Office, Austin.

2004a Environment, Cultural Chronologies, and Previous Archaeology. In Archaeological Evaluation of Sandy Mantle Prehistoric and Historic Sites at Camp Swift, Bastrop County, Texas: 2003, by David L. Nickels and Melissa Lehman, pp. 3-12. Archaeological Studies Report No. 5. Center for Archaeological Studies, Texas State University-San Marcos.

2004b Summary and Recommendations. In Archaeological Evaluation of Sandy Mantle Prehistoric and Historic Sites at Camp Swift, Bastrop County, Texas: 2003, by David L. Nickels and Melissa Lehman, pp. 127-132. Archaeological Studies Report No. 5. Center for Archaeological Studies, Texas State University-San Marcos.

2005a Introduction. In An Archaeological Survey of 307 Acres at Camp Swift, Bastrop County, Texas: 2003, by David L. Nickels, Antonio E. Padilla, and James E. Barrera, pp. 1-2. Archaeological Studies Report No. 6. Center for Archaeological Studies, Texas State University-San Marcos.

2005b Research Design Issues. In An Archaeological Survey of 307 Acres at Camp Swift, Bastrop County, Texas: 2003, by David L. Nickels, Antonio E. Padilla, and James E. Barrera, pp. 73-94. Archaeological Studies Report No. 6. Center for Archaeological Studies, Texas State University-San Marcos.

In prep Archaeological Phase II Testing of Twenty Sites at Camp Swift, Bastrop County, Texas. Archaeological Report Series, Center for Archaeological Studies, Texas State University-San Marcos. Manuscript in preparation. 
Nickels, David L., and Melissa Lehman

2004a Archaeological Evaluation of Sandy Mantle Prehistoric and Historic Sites at Camp Swift: Bastrop County, Texas: 2003. Archaeological Studies Report No. 5. Center for Archaeological Studies, Texas State University-San Marcos.

2004b Site Descriptions, Analysis, and Recommendations. In Archaeological Evaluation of Sandy Mantle Prehistoric and Historic Sites at Camp Swift: Bastrop County, Texas: 2003, by David L. Nickels and Melissa Lehman, pp. 19-106. Archaeological Studies Report No. 5. Center for Archaeological Studies, Texas State University-San Marcos.

Nickels, David L., Melissa L. Lehman, and C. Britt Bousman

2003 Archaeological Evaluation of 39 Category V Sites at Camp Swift, Bastrop County, Texas: 2001. Archaeological Studies Report No. 3. Center for Archaeological Studies, Southwest Texas State University, San Marcos.

Nickels, David L., and Antonio E. Padilla

2005 Project Area Descriptions. In An Archaeological Survey of 307 Acres at Camp Swift, Bastrop County, Texas: 2003, by David L. Nickels, Antonio E. Padilla, and James E. Barrera, pp. 3-10. Archaeological Studies Report No. 6. Center for Archaeological Studies, Texas State University-San Marcos.

Nickels, David L., Antonio E. Padilla, and James E. Barrera

2005 An Archaeological Survey of 307 Acres at Camp Swift, Bastrop County, Texas: 2003. Archaeological Studies Report No. 6. Center for Archaeological Studies, Texas State University-San Marcos.

Nightengale, Bruce A., and Henry B. Moncure

1996 Intensive Cultural Resource Survey and Monitoring at the LCRA Camp Swift Regional Wastewater Project, Bastrop County, Texas. Cultural Resources Report No. 3. Lower Colorado River Authority, Environmental Protection Division, Austin, Texas.

Oviatt, Charles G., David B. Madsen, and Dave N. Schmitt

2003 Late Pleistocene and Early Holocene Rivers and Wetlands in the Bonneville Basin of Western North America. Quaternary Research 60(2003):200-210.

Patterson, Leland W.

1995 The Archeology of Southeast Texas. Bulletin of the Texas Archeological Society 66:239-264.

Prewitt, Elton R.

1974 Archeological Investigations at the Loeve-Fox Site, Williams County, Texas. Research Report No. 49. Texas Archeological Survey, The University of Texas at Austin.

1981 Cultural Chronology in Central Texas. Bulletin of the Texas Archeological Society 52:65-89.

1985 From Circleville to Toyah: Comments on Central Texas Chronology. Bulletin of the Texas Archeological Society 54:210-238. 
Prochnow, Shane

2001 Geoarchaeological Assessment. In An Archaeological Inventory of Camp Swift, Bastrop County, Texas, edited by Barbara A. Meissner, pp. 31-37. Archaeological Survey Report No. 316. Center for Archaeological Research, The University of Texas at San Antonio.

Ricklis, Robert A.

1994 Toyah Components: Evidence for Occupation in the Project Area During the Latter Part of the Late Prehistoric Period. In Archaic and Late Prehistoric Human Ecology in the Middle Onion Creek Valley, Hays County, Texas, by Robert A. Ricklis and Michael B. Collins, pp. 207-316. Studies in Archeology 19. Texas Archeological Research Laboratory, The University of Texas at Austin.

2005 Analysis of Findings at the Buckeye Knoll Site (41VT98), Victoria County, Texas: Quarterly Report No. 5 (Through January 24, 2005). Electronic document, http://www.swg.usace.army. mil/pe/41VT98/QR/QuarterlyReport5.pdf, accessed 12 October, 2005.

Ricklis, Robert A. (editor)

2001 National Register Eligibility Testing at 41LE177, Alcoa Sandow Mine, Lee County, Texas: Archaeological, Geological, and Paleoenvironmental Assessment of an Upland Sandy Mantle Site. Coastal Archaeological Research, Inc., Corpus Christi.

Robinson, David G.

2001 Results - Multi-Component. In An Archaeological Inventory of Camp Swift, Bastrop County, Texas, edited by Barbara A. Meissner, pp. 118-143. Archaeological Survey Report No. 316. Center for Archaeological Research, The University of Texas at San Antonio.

Robinson, David G., and Timothy M. Meade

2001 Project Area. In An Archaeological Inventory of Camp Swift, Bastrop County, Texas, edited by Barbara A. Meissner, pp. 3-7. Archaeological Survey Report No. 316. Center for Archaeological Research, The University of Texas at San Antonio.

Rogers, Robert

1995a Archaeological Investigations at the Chesser Site (41LE59) at the Sandow Mine, Lee County, Texas. Espey, Huston and Associates, Inc. Austin.

1995b Excavations at Sites 41GM166, 41GM281, and 41GM282 at the Gibbons Creek Lignite Mine, Grimes County, Texas. Espey, Huston and Associates, Inc. Austin.

Root, Matthew J., Jerry D. William, Marvin Kay, and Lisa K. Shifrin

1999 Folsom Ultrathin Biface and Radial Break Tools in the Knife River Flint Quarry Area. In Folsom Lithic Technology: Explorations in Structure and Variation, edited by Daniel S. Amick, pp. 144-168. International Monographs in Prehistory, Archaeology Series 12. University of Michigan, Ann Arbor. 
Schmidt, James S., and Maria E. Cruse

1995 Cultural Resources Survey, Camp Swift, Bastrop County, Texas. Espey, Huston, and Associates, Inc., Austin.

Sellards, E. H., W. S. Adkins, and F. B. Plummer

1932 The Geology of Texas: Volume 1, Stratigraphy. Bulletin No. 3232. Bureau of Economic Geology, The University of Texas at Austin.

Skelton, Duford W., and Martha Doty Freeman

1979 A Cultural Resource Inventory and Assessment at Camp Swift, Texas. Research Report No. 72. Texas Archeological Survey, The University of Texas at Austin.

Soil Survey Staff

1993 Soil Survey Manual. U. S. Department of Agriculture Handbook Number 18. U. S. Government Printing Press, Washington, D.C.

Sorrow, William M., Harry J. Shafer, and Richard E. Ross

1967 Excavations at Stillhouse Reservoir. Papers of the Texas Archeological Salvage Project No. 11. Texas Archeological Salvage Project, The University of Texas at Austin.

Story, Dee Ann

1985 Adaptive Strategies of Archaic Cultures of the West Gulf Coastal Plain. In Prehistoric Food Production in North America, edited by Richard I. Ford, pp. 19-56. Anthropological Papers No. 75. Museum of Anthropology, University of Michigan, Ann Arbor.

Story, Dee Ann, Janice A. Guy, Barbara A. Burnett, Martha Doty Freeman, Jerome C. Rose, D. Gentry Steele, Ben W. Olive, and Karl J. Reinard

1990 The Archeology and Bioarcheology of the Gulf Coastal Plain. 2 volumes. Research Series No. 38. Arkansas Archeological Survey, Fayetteville.

Suhm, Dee Ann

1957 Excavations at the Smith Rockshelter, Travis County, Texas. The Texas Journal of Science 9:26-58.

Sullo, D. M., and Alan J. Wormser

1996 Archeological Survey for Proposed Bradley Fighting Vehicle Training "Area A" at Camp Swift Military Reservation, Bastrop County, Texas. The Adjutant General’s Department of Texas, Austin. 
Thoms, Alston V.

1993 Buried in the Sandy Mantle: site formation in the Post Oak Savannah. In The Brazos Valley Slopes Archaeological Project: cultural resources assessments for the Texas A\&M University Animal Science Teaching and Research Complex, Brazos County, Texas, edited by Alston V. Thomas, pp. 51-60. Reports of Investigations No. 14, Archaeological Research Laboratory, Texas A\&M University, College Station.

Waters, Michael R.

1992 Principals of Geoarchaeology: A North American Perspective. University of Arizona Press, Tucson.

Weir, Frank A.

1976 The Central Texas Archaic. Unpublished doctoral dissertation, Department of Anthropology, University of Washington, Pullman.

Wilbarger, J. W.

1985 Indian Depredations in Texas: Original Narratives of Texas History and Adventure, 1885. Reprinted by Eakin Press, Austin.

Wilding, Larry P.

2000 Classification of Soils. In Handbook of Soil Science, edited by Malcolm E. Summer, pp. E175-E-392. CRC Press, Boca Raton.

Willey, Gordon R., and Phillip Phillips

1958 Method and Theory in American Archaeology. University of Chicago Press, Chicago.

Wilmarth, M. Grace (compiler)

1938 Lexicon of Geologic Names of the United States (Including Alaska). 2 vols. Bulletin 896. Geological Survey, United States Department of the Interior, U. S. Government Printing Office, Washington, D.C.

Wormington, Hannah M.

1957 Ancient Man in North America. $4^{\text {th }}$ ed. Denver Museum of Natural History, Denver.

Wyckoff, Donald G.

1995 A Summary of the Calf Creek Horizon in Oklahoma. Bulletin of the Oklahoma Anthropological Society 42:179-210. 